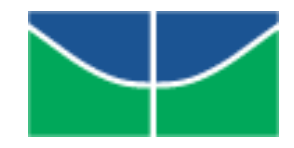

Universidade de Brasília - Instituto de Psicologia

Departamento de Psicologia Escolar e do Desenvolvimento - PED

Programa de Pós-Graduação em Processos de Desenvolvimento Humano e Saúde

PG-PDS

AS ADOLESCENTES E A MEDIDA SOCIOEDUCATIVA DE

INTERNAÇÃO: ROMPENDO O SILÊNCIO

DANIELA LEMOS PANTOJA COELHO DE OLIVEIRA

COSTA

Brasília - DF, março de 2015 


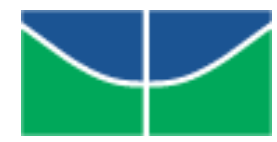

Universidade de Brasília - Instituto de Psicologia

Departamento de Psicologia Escolar e do Desenvolvimento - PED

Programa de Pós-Graduação em Processos de Desenvolvimento Humano e Saúde

PG-PDS

\section{AS ADOLESCENTES E A MEDIDA SOCIOEDUCATIVA DE \\ INTERNAÇÃO: ROMPENDO O SILÊNCIO}

DANIELA LEMOS PANTOJA COELHO DE OLIVEIRA COSTA

Dissertação apresentada ao Instituto de Psicologia da Universidade de Brasília, como requisito parcial para a obtenção do título de Mestre em Processos de Desenvolvimento Humano e Saúde, área de concentração Desenvolvimento Humano e Educação.

Orientadora: Professora Doutora Maria Cláudia Santos Lopes de Oliveira

Brasília - DF, março de 2015 
Ficha catalográfica elaborada automaticamente, com os dados fornecidos pelo(a) autor(a)

Costa, Daniela Lemos Pantofa Coelno de oliveira As Adolescentea e a Nedida Socloeducativa de Internaçao: rompendo o silencio / Daniela Lemog Pantoja Coelno de oliveira Costa; orientador Maria Claudia Santos Lopeg de Oliveira. -- Brasilia, 2015. $176 \mathrm{p}$.

Diasertaça (Mestrado - Mestrado en Processos de Desenvolvimento Humano e Safide) -. universidade de Brasilia, 2015.

1. Degenvolvimento Hunano. 2. Adolescenc1a. 2. Socioeducaçao. 4. Cenero. I. Lopes de Olive1ra, Maria clíudia Santos, ortent. II. Titulo. 
UNIVERSIDADE DE BRASÍLIA

INSTITUTO DE PSICOLOGIA

DISSERTAÇÃO DE MESTRADOAPROVADA PELA SEGUINTE BANCA EXAMINADORA:

Prof. ${ }^{a}$ Dr. ${ }^{a}$ Maria Cláudia Santos Lopes de Oliveira - Presidente

Universidade de Brasília

Prof. ${ }^{a}$ Dr. ${ }^{a}$ Regina Lúcia Sucupira Pedroza

Universidade de Brasília

Prof. ${ }^{a}$ Dr. ${ }^{a}$ Tatiana Yokoy de Souza

SEDH- DF

Prof. ${ }^{a}$ Dr. ${ }^{a}$ Sueli de Souza Dias-Suplente

SEDF 


\section{Agradecimentos}

Uma pesquisa de mestrado se constrói a partir de muitos olhares e diferentes perspectivas. Ao longo do caminho descobre-se um mundo infinito de possibilidades, dentre as quais é preciso selecionar aquelas que mais fundo tocam ao coração do/a pesquisador/a. Assim, agradeço de coração, corpo e alma a todos que me acompanharam nesta caminhada e que, de um modo ou de outro, me ajudaram nestas escolhas!

Agradecimentos especiais às adolescentes que participaram dessa pesquisa contribuindo com narrativas riquíssimas que ficarão para sempre guardadas em meu coração.

À minha mãe, Hilda, pelo amor incondicional e todo o apoio nessa viagem deliciosa que foi o Mestrado! Por todas as aulas de produção de texto ao longo da minha vida e, claro, pelo título desta Dissertação!

Ao meu amor - Wellington, meu marido e anjo da guarda, que ao longo dos últimos 14 anos tem contribuído imensamente com o desenvolvimento da minha autoestima e autoconfiança, sem os quais este trabalho jamais poderia ter se realizado.

À minha família, que mesmo longe esteve sempre perto com palavras de carinho e incentivo. À Preta, minha colaboradora doméstica, pelos inúmeros cafezinhos providenciais!

À minha orientadora, Maria Cláudia, que não me canso de repetir, foi um presente de Deus em meu caminho. Os aprendizados, os momentos de parceria e o apoio jamais serão esquecidos.

Aos colegas do GAIA: Alexandre, Ana Claudia, Carolina (queridíssima auxiliar de pesquisa), Cássio, Cláudio, Davi, Dayane, Fernanda, Jaqueline, Kélita, Marcos, Raíssa e Suely. Aos colegas e às professoras do LABMIS: Prof ${ }^{\mathrm{a}}$ Angela Branco, Prof ${ }^{\mathrm{a}}$ 
Diva Maciel, Albenira, Daniela, Francisco, Letícia, Milena, Mônica, Patrícia e Priscila pelos ricos momentos de discussão. A todos esses, obrigada também pela amizade que fica!

À Secretaria de Educação e da Criança, pelo apoio institucional. Às equipes de direção das Unidades de Internação do Recanto das Emas - UNIRE e de Santa Maria UISM pelo apoio e confiança para a realização desta pesquisa. Aos colegas do Sistema Socioeducativo do DF pelos ricos momentos de trocas de ideias. Aos colegas professores, especialmente à Ana Clara Libório, Sylvia Barbosa (amiga querida!), Izabel Ledes, Leila Resende, Lua Braga, Luiz Nolasco Jr, Rodrigo Xavier, Sanderson Batista, Ismênia Coelho, William Luzente e Isabella Paiva pelo apoio e incentivo para que este projeto tomasse corpo. À Joamara Moraes pela parceria.

Às professoras Tatiana Yokoy, Regina Pedroza e Sueli Dias que gentilmente aceitaram participar da banca que avaliou esse trabalho.

À minha amiga, Laura Giovanna, pela amizade infinita!

Ao meu padrinho, compadre, tio e amigo, Amarildo de Paula, que tão ricamente me ajudou e apoiou durante o meu período de adaptação ao universo do atendimento socioeducativo.

E um agradecimento mais do que especial à minha filha amada, Joana, que com tão pouca idade soube compreender as minhas ausências, e com astúcia transformou os momentos de dedicação a este estudo em momentos de companheirismo e diversão,passando dias inesquecíveis comigo na biblioteca da UnB!

And last but not least a Deus, pela vida! 
Dedico este estudo à minha mãe, que me ensinou a ser quem eu sou, ao meu marido, que me fez ver quem eu sou e à minha filha, que me faz ser a cada dia melhor. 
Aos esfarrapados do mundo e aos que neles se descobrem e, assim descobrindo-se, com eles sofrem, mas, sobretudo, com eles lutam.

Paulo Freire 


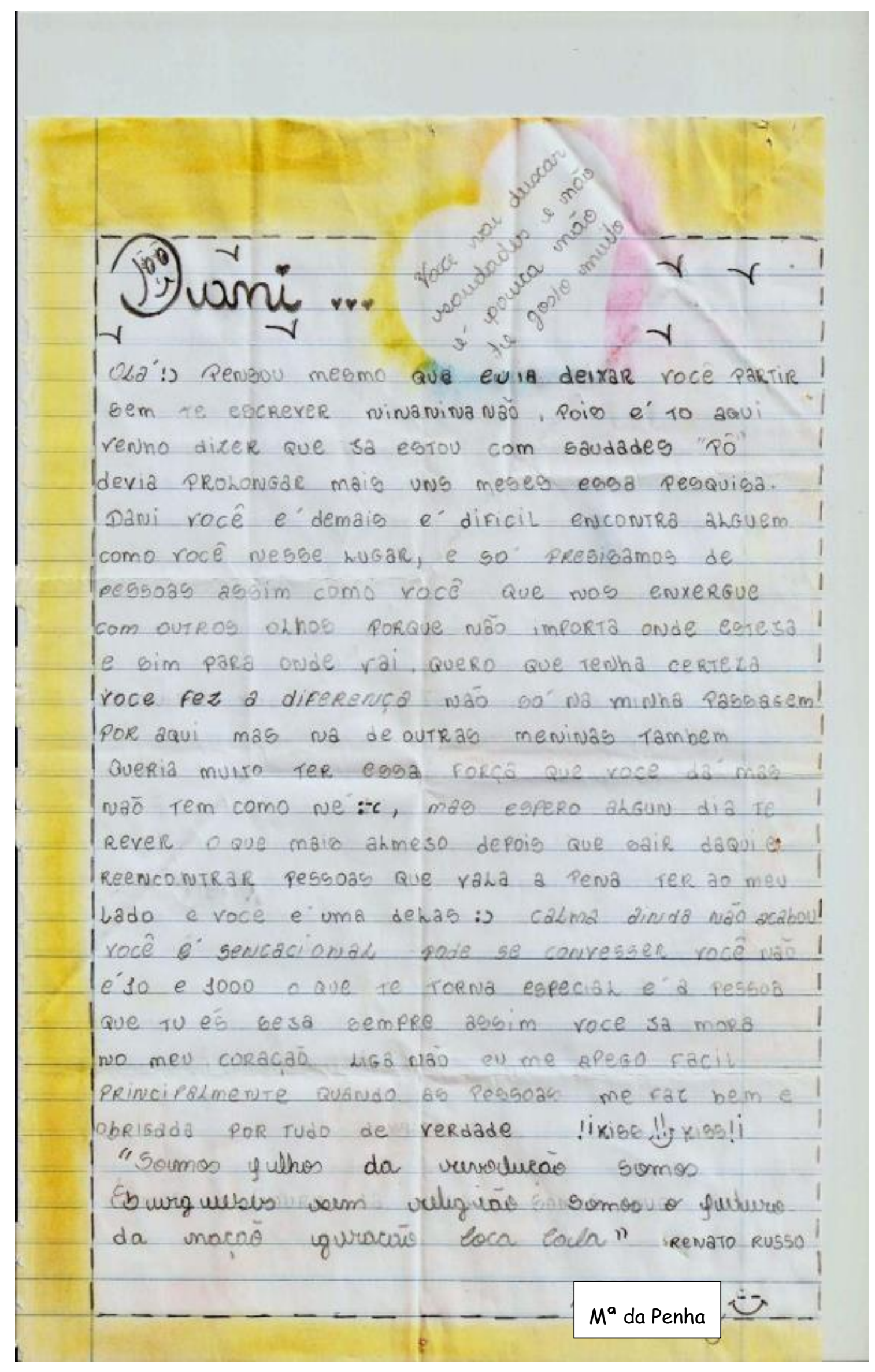




\section{Resumo}

O cotidiano das relações sociais e das normas institucionais vivenciado pelas adolescentes nas unidades de internação, ao longo do cumprimento de medida socioeducativa, constitui um tema ainda pouco investigado. A presente pesquisa aborda o tema da infração juvenil feminina a partir de uma perspectiva teórico-metodológica que integra o modelo sociocultural do desenvolvimento humano aos estudos de gênero. Os processos de desenvolvimento subjetivo das adolescentes que cumprem medida socioeducativa de internação constituem o objeto de investigação privilegiado neste estudo. O objetivo central do trabalho foi investigar como essas adolescentes significam o processo socioeducativo. Para tanto, adotou-se a metodologia da pesquisa-intervenção em que, por meio de uma oficina pedagógica denominada Oficina de Reflexão foram discutidos e problematizados diversos aspectos do processo socioeducativo. A intervenção foi realizada ao longo de dez encontros nos quais diferentes recursos simbólicos como músicas, textos e vídeos foram utilizados no intuito de evocar reflexões e narrativas que motivassem posicionamentos pessoais das adolescentes sobre as especificidades do atendimento socioeducativo. Participaram da Oficina de Reflexão a pesquisadora, uma auxiliar de pesquisa e 11 adolescentes do sexo feminino que à época cumpriam medida socioeducativa de internação. As sessões de intervenção foram gravadas em áudio e a análise qualitativa dos dados foi realizada à luz de quatro dimensões de análise, a saber: Promoção de Desenvolvimento $\leftrightarrow$ Privação de Liberdade; O Olhar das Adolescentes Sobre a Instituição Socioeducativa $\leftrightarrow$ O Olhar Institucional Sobre a Infração Juvenil Feminina; Interação Social $\leftrightarrow$ Isolamento; Processos Reflexivos $\leftrightarrow$ Reprodução do Discurso Institucional. As análises evidenciaram que as adolescentes em cumprimento de medidas socioeducativas lidam com dificuldades ainda mais complexas que os adolescentes porque, entre outras razões, o universo socioeducativo ainda é fortemente marcado por uma cultura masculina. Sendo assim, as assimetrias de gênero são sustentadas por crenças e valores sexistas que permeiam o atendimento socioeducativo. Elas se manifestam, sobretudo, por meio de atitudes de discriminação às adolescentes acauteladas. Desse modo, os resultados levam à compreensão de que as adolescentes se tornam objeto de um processo de exclusão social como parte de um contexto institucional que favorece a reprodução de normas patriarcais dominantes que contribuem para a invisibilização da infração juvenil feminina no contexto investigado.

Palavras-chave: Infração juvenil feminina; Socioeducação; Desenvolvimento humano;

Gênero. 


\begin{abstract}
The social relations and institutional rules experienced on a daily basis by female adolescents fulfilling socio-educational measures in detention facilities is a topic not yet thoroughly investigated. This study addresses the issue of female juvenile delinquency from a theoretical and methodological perspective that integrates the socio-cultural model of human development to gender studies. The subjective development processes of adolescents fulfilling socio-educational measures of internment are the focus of this study, whose main goal was to investigate how these female adolescents signify the socio-educational process. The methodology used was intervention research in which, through a pedagogical workshop called Reflection Workshop, different aspects of the socio-educational process were discussed and called into question. The intervention was conducted over ten meetings in which different symbolic representations such as songs, texts and videos were used in order to evoke thoughts and narratives that would motivate the young girls to express their personal views on specific aspects of socialeducational assistance. Participants in the Reflection Workshop included the researcher, a research assistant and 11 female adolescents who at that time were fulfilling socioeducational measures of internment. The intervention sessions were audio-recorded and a qualitative data analysis was carried out in the light of four analysis dimensions, namely: Promotion of Development $\leftrightarrow$ Deprivation of Freedom; The Young Girls' Views on the Socio-educational Institution $\leftrightarrow$ The Institutional View on Female Juvenile Delinquency; Social Interaction $\leftrightarrow$ Isolation; Reflective Processes $\leftrightarrow$ Reproduction of the Institutional Discourse. The analysis showed that female adolescents in fulfillment of educational measures face much more complex problems than male adolescents because, among other reasons, the socio-educational universe is still strongly dominated a male-oriented culture. Gender asymmetries are therefore supported by sexist beliefs and values that permeate all activities related to socioeducational assistance. They are expressed mainly through discriminatory behaviors against female adolescents under protective measure. Finally, the results lead to the realization that female adolescents become the subject of a process of social exclusion as part of an institutional context that favors the reproduction of a dominant patriarchal order that contributes to the invisibility of female juvenile delinquency in the context investigated.
\end{abstract}

Keywords: Female juvenile delinquency; Socio-education; Human development; Gender. 


\section{Sumário}

Página

Capítulo I: Apresentação... .01

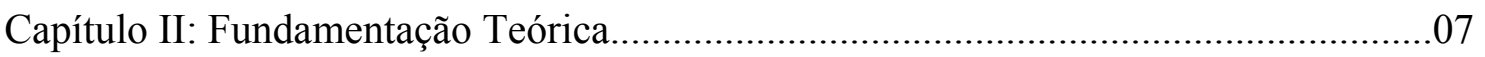

1. Desenvolvimento Humano e Cultura........................................................................

1.1. A contribuição de Vigotski para a Psicologia Cultural............................09

1.2. A Psicologia Cultural: desdobramentos da abordagem de Lev Vigotski. 11

1.3. A cultura como fenômeno de fronteira.....................................................12

1.4. Sujeito reflexivo: processos narrativos como contexto de produção de subjetividade.

2. Adolescência(s): processos de desenvolvimento e desafios contemporâneos .17

2.1 A adolescência na perspectiva Sociocultural........................................ 18

2.2 A relevância das questões de gênero na adolescência............................19

3. A infração juvenil feminina e a proteção integral no atendimento socioeducativo .22

3.1 Adolescentes como sujeitos de direitos. .22

3.2 Quem são as adolescentes que cumprem MSE no

Brasil. .24

3.3 A Infração juvenil feminina no DF: uma breve contextualização histórica. .29

3.4 A MSE de Internação: histórico do atendimento no Distrito Federal 
3.5 $\mathrm{O}$ atendimento socioeducativo às adolescentes no Distrito Federal: trajetória e transformações.

Capítulo III: Objetivos. .45

Capítulo IV: Metodologia. .46

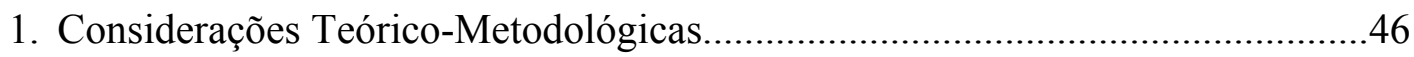

2. Método.

2.1 Procedimentos e Cuidados Éticos. .50

2.2 Contexto de Realização da Pesquisa. .51

2.3 Procedimento de construção das Informações da Pesquisa.

2.4 Seleção das participantes. .62

2.5 A Intervenção - Oficina de Reflexão .67

3. Procedimento de análise das informações construídas nos encontros da Oficina...... .78

3.1 Construção dos episódios de análise. .82

Capítulo V: Resultados e Discussão. .84

Dimensão 1. Promoção de Desenvolvimento $\leftrightarrow$ Privação de Liberdade. .84

Dimensão 2. O Olhar das Adolescentes Sobre a Instituição Socioeducativa $\leftrightarrow$ O $\begin{array}{lllll}\text { Olhar Institucional } & \text { Sobre } & \text { a } & \text { Infração }\end{array}$ Feminina. .98 
Dimensão 3. Interação Social $\leftrightarrow$ Isolamento.

108

Dimensão 4. Processos Reflexivos ↔ Reprodução do Discurso Institucional.......113

Capítulo VI: Considerações Finais 122

Referências Bibliográficas 129

Apêndices 136 


\section{Lista de Tabelas}

Página

Tabela 1 - Dados estatísticos de adolescentes em cumprimento de MSE de Internação Estrita e tipo de ato infracional cometido. .26

Tabela 2 - Dados estatísticos de adolescentes em internação provisória e em cumprimento de MSE no Distrito Federal.

Tabela 3 - Unidades de Internação provisória e de MSE de Internação no Distrito Federal. .39

Tabela 4 - Informações básicas das participantes da Oficina de Reflexão. .62

Tabela 5 - Participação nos encontros da Oficina de Reflexão. 63

Tabela 6-Dimensões de análise. .80 


\section{Lista de Apêndices}

Página

Apêndice 1 - Autorização judicial para a realização da pesquisa com adolescentes em cumprimento de MSE de Internação no DF. 136

Apêndice 2 - Aceite institucional. 137

Apêndice 3 - Termo de Assentimento. 138

Apêndice 4 - Atividades desenvolvidas pelas adolescentes nas aulas de Arte "Desconstruindo estereótipos de gênero através de máscaras". 140

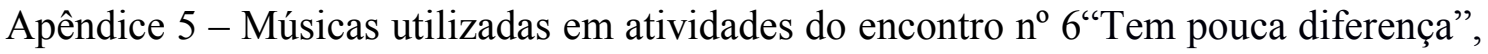
Gal Costa e Luiz Gonzaga; "Masculino e Feminino", Pepeu Gomes; "Lavagem Cerebral”, Gabriel O Pensador. .146

Apêndice 6 - Imagem "Biscoito Sexual”. .150

Apêndice 7 - Mural dos Desejos.

Apêndice 8 - Música utilizada em atividades do encontro no 9 - "Rosas", Atitude Feminina. 152

Apêndice 9 - Pseudônimos das adolescentes na pesquisa 155

Apêndice 10 - Texto utilizado em atividade do encontro $\mathrm{n}^{\mathrm{o}} 10$ "As mentiras que contam sobre nós"; Aline Valek. 157 


\section{Lista de Siglas}

ATRS: Atendente de Reintegração Social

CAJE: Centro de Atendimento Juvenil Especializado

CESAMI: Centro Socioeducativo Amigoniano

CIAGO: Unidade de Internação da Granja das Oliveiras

CNACL: Cadastro Nacional de Adolescentes em Conflito com a Lei

CONANDA: Conselho Nacional dos Direitos da Criança e do Adolescente

ECA: Estatuto da Criança e do Adolescente

GDF: Governo do Distrito Federal

MSE: Medida Socioeducativa

MSE de LA: Medida Socioeducativa de Liberdade Assistida

MSE de PSC: Medida Socioeducativa de Prestação de Serviços à Comunidade

NAI: Núcleo de Atendimento Integrado

SECRIA: Secretaria de Estado da Criança

SINASE: Sistema Nacional de Atendimento Socioeducativo

SUBSIS: Subsecretaria do Sistema Socioeducativo

UIPP: Unidade de Internação do Plano Piloto

UIPSS: Unidade de Internação Provisória de São Sebastião 
UISM: Unidade de Internação de Santa Maria

UISS: Unidade de Internação de São Sebastião

UNIRE: Unidade de Internação do Recanto das Emas

VEMSE: Vara de Execução de Medidas Socioeducativas

VIJ - DF: Vara da Infância e Juventude do Distrito Federal 


\section{Capítulo I:}

\section{Apresentação}

Esta pesquisa foi motivada pelo meu interesse em investigar e compreender como as adolescentes em cumprimento de medida socioeducativa de internação no Distrito Federal significam o processo socioeducativo, que constitui o principal objetivo do estudo em questão.

O atendimento socioeducativo é garantido pela Constituição Federal do Brasil e regulamentado pela lei 8.069, de 13 de julho de 1990, também conhecida como ECA Estatuto da Criança e do Adolescente. Com o objetivo de nortear e regulamentar a execução das medidas socioeducativas - MSE destinadas ao/à adolescente que pratique atos infracionais, foi criado o SINASE- Sistema Nacional de Atendimento Socioeducativo, sancionado pela lei 12.594 , de 18 de janeiro de 2012. De acordo com a Resolução 119/2006 CONANDA, documento que institui o SINASE, sua implementação objetiva primordialmente o desenvolvimento de uma ação socioeducativa baseada nos princípios dos direitos humanos. Nesse sentido, defende o alinhamento conceitual, estratégico e operacional, estruturado, principalmente, em bases éticas e pedagógicas.

Todavia, apesar de a legislação brasileira assegurar esses direitos aos/às adolescentes em cumprimento de MSE e, embora o Estado tenha formalizado o seu sistema de justiça juvenil fundamentado na promoção e proteção dos direitos humanos, na prática, isso nem sempre se comprova.

Minha experiência como educadora em escolas em unidades de medida socioeducativa de internação, por mais de uma década, evidencia que as adolescentes 
infratoras lidam com dificuldades ainda maiores do que os adolescentes, visto que o universo socioeducativo é fortemente marcado por uma cultura masculina (Abramovay \& cols., 2005; Assis \& Constantino, 2001). Essas adolescentes, sendo parte de um contexto institucional que muitas vezes favorece a internalização de significados pautados em concepções de gênero naturalizantes e deterministas, vivenciam um processo de exclusão social que se sustenta em diferentes expressões de preconceito. Nesse sentido, significados culturais que se referem a atividades ilegais costumam excluir as adolescentes desse cenário de risco e violência, alimentando o preconceito em relação ao envolvimento de adolescentes do sexo feminino no universo infracional.

Ao longo desses mais de dez anos, inúmeros foram os comentários que ouvi dos/das educadores/as sociais (profissionais que atuam na socioeducação) acerca das muitas dificuldades que encontram no desenvolvimento do trabalho socioeducativo com as adolescentes. Comparações entre os meninos e as meninas são muito comuns, ficando elas, normalmente, rotuladas como "difíceis de lidar". Entretanto, durante todo esse tempo lecionei sempre em turmas mistas - compostas por meninos e meninas - e, por mais que eu procurasse motivos que me levassem a concordar com essas diferenças e/ou dificuldades, nunca os encontrava. Na realidade, o dia a dia em sala de aula mostrava o contrário do que afirmavam esses/as educadores/as, pois o trabalho com as meninas era, a meu ver, consideravelmente menos tenso do que com os meninos, visto que as discussões e os desentendimentos eram muito menos frequentes entre elas.

Tais posicionamentos frente às adolescentes que cometeram atos infracionais, nos dias atuais, nos remetem aos estudos sobre a criminalidade feminina, desenvolvidos ainda no século XIX por Cesare Lombroso e Giovanni Ferrero, na obra La Donna Delinquente, de 1892. Eles descreveram as mulheres como potencialmente amorais, enganosas, frias, calculistas e malévolas, entre outras características igualmente 
depreciativas. Segundo Espinoza (2002) a imagem da mulher foi construída ao longo do tempo como um sujeito fraco em corpo e em inteligência, um produto de falhas genéticas, sendo essa a perspectiva na qual se baseou a criminologia positivista quando se ocupou da mulher criminosa. E, embora a criminologia crítica represente uma revolução epistemológica extremamente relevante, no Brasil ainda são poucos os estudos sobre a condição da mulher (seja como autora ou vítima de crimes) que reconhecem e problematizam os processos de criminalização sob a perspectiva de gênero (Mendes, 2014).

Ademais, a concepção muitas vezes naturalizada - de que o atendimento às adolescentes é mais difícil, chato e trabalhoso do que o atendimento aos adolescentesfez crescer em mim uma inquietação e uma vontade de compreender o porquê dessas afirmações. Contudo, faz-se necessário explicar que embora o meu desejo como pesquisadora seja o de investigar essas diferenças a partir de vários pontos de vista, ou seja, sob a perspectiva de diferentes atores do Sistema Socioeducativo (até porque não há aqui a intenção de contribuir com uma visão unilateral e preconceituosa do atendimento), por se tratar de um estudo de Mestrado, o tempo disponível para a realização da pesquisa não comportaria um desenho empírico extenso e mais complexo.

Nesse sentido, optamos pela narrativa das adolescentes como fonte principal de informação, visto que a intenção foi trazer à luz a especificidade do lugar da adolescente do sexo feminino em um cenário majoritariamente masculino. Para isso, procurou-se conceber a produção de saber sobre elas e sobre o lugar que ocupam dentro do SSE, a partir de suas próprias concepções e pontos de vista sobre esse contexto. Cabe ressaltar que a proposta do estudo em questão, desde o início, era a de que essas narrativas acontecessem de forma espontânea, em um espaço onde as adolescentes se sentissem confortáveis para tratar de temas que normalmente trazem angústias, raiva e um 
sentimento (tantas vezes comum) de inferioridade. Desse modo, optamos pela realização de uma pesquisa-intervenção, por entendermos que essa metodologia privilegiaria a produção compartilhada das informações da pesquisa e que, ao mesmo tempo, poderia favorecer processos de transformação (pessoal e sócio-institucional).

Para tanto, achamos importante ressaltar que o êxito da intervenção - bem como da pesquisa como um todo - é fruto de um vínculo afetivo, de confiança e de respeito que foi estabelecido desde o início entre as pesquisadoras e as pesquisandas.

Ainda, seguindo o que propôs Yokoy de Souza (2007) em seu estudo de Mestrado, adotamos como nomenclatura, para fazer referência às adolescentes participantes dessa pesquisa, os termos "adolescente que cumpre medida socioeducativa e/ou adolescente que comete ato infracional", por entender que outras nomenclaturas comumente utilizadas, como "adolescente em conflito com a lei e/ou adolescente infratora" reiteram a concepção negativa da adolescência e as reduzem ao status de meras contraventoras, desconsiderando o seu potencial de ressignificação e a possibilidade de desenvolvimento de uma nova trajetória de vida descomprometida com a infração.

Face ao exposto, pretendemos com esse estudo trazer à luz as reflexões das adolescentes sobre o processo socioeducativo, bem como contribuir com 0 aprofundamento das reflexões sobre o processo histórico de invisibilização da infração juvenil feminina. Para isso, adotamos como arcabouço teórico a perspectiva da psicologia sociocultural que enfatiza o papel ativo do sujeito em seu desenvolvimento, articulada aos estudos de gênero.

Feitas essas considerações, apresentamos ao leitor, sucintamente, a estrutura em que se organiza este estudo: capítulo I: Apresentação; capítulo II: Fundamentação 
Teórica; capítulo III: Objetivos; capítulo IV: Metodologia; capítulo V: Resultados e Discussão e capítulo VI: Considerações Finais.

O capítulo teórico está dividido em três seções, nas quais apresentamos ao leitor os pressupostos teórico-epistemológicos adotados para a compreensão do fenômeno a ser investigado. Assim, na primeira seção discorremos sobre os processos de desenvolvimento humano sob a perspectiva da psicologia sociocultural. $\mathrm{Na}$ segunda seção nos dedicamos à compreensão da adolescência sob a perspectiva SemióticoCultural. Na terceira e última seção desse capítulo trazemos à luz o tema da infração juvenil feminina especificamente situada no contexto das medidas socioeducativas do Distrito Federal.

No capítulo metodológico apresentamos a filiação epistemológica do trabalho em questão, bem como os procedimentos de construção e análise das informações de pesquisa e o contexto onde se realizou esse estudo. Ainda nesse capítulo apresentamos ao leitor o caminho metodológico utilizado para a criação de um espaço de interação e de (re)negociação de sentidos e significados entre as participantes da pesquisa (pesquisadoras e adolescentes), o qual denominamos Oficina de Reflexão.

No capítulo Resultados e Discussão são apresentados e discutidos os dados resultantes dessa intervenção. Para isso foram consideradas quatro dimensões, à luz das quais as narrativas das adolescentes foram analisadas: (a) promoção de desenvolvimento $\leftrightarrow$ privação de liberdade; (b) o olhar das adolescentes sobre a instituição socioeducativa $\leftrightarrow$ o olhar institucional sobre a infração juvenil feminina; (c) interação social $\leftrightarrow$ isolamento; (d) processos reflexivos $\leftrightarrow$ reprodução do discurso institucional.

No capítulo Considerações Finais traçamos junto ao leitor um olhar retrospectivo ao processo de construção e de interpretação das informações da pesquisa. 
Por fim, sugerimos um olhar mais atento ao fenômeno da infração juvenil feminina e às possíveis consequências da discriminação institucional no desenvolvimento subjetivo das adolescentes que cumprem medidas socioeducativas. 


\section{Capítulo II:}

\section{Fundamentação Teórica}

Este capítulo está organizado em três seções. Na primeira, exploraremos o tema do Desenvolvimento Humano sob a perspectiva da psicologia sociocultural. Para isso traremos algumas reflexões acerca das contribuições de Vigotski para a Psicologia Cultural, como também sobre os desdobramentos e a influência de sua teoria no conceito de cultura que adotamos para este estudo. Nessa mesma seção, o enfoque recairá sobre a relação bidirecional sujeito-cultura, o papel ativo do sujeito em seu desenvolvimento e os processos narrativos como contexto de produção da subjetividade.

A segunda seção será dedicada à concepção da adolescência sob a perspectiva Sociocultural. Para tanto é fundamental que se compreenda o desenvolvimento do/da adolescente como um processo situado histórico-culturalmente, mediado por circunscritores culturais como classe social, gênero e etnia. Enfoque será dado às questões de gênero na adolescência, uma vez que nos interessa compreender os processos de desenvolvimento psicológico das adolescentes que cumprem medida socioeducativa de internação.

A terceira e última seção desse capítulo refere-se ao tema da infração juvenil feminina, com destaque para o contexto das medidas socioeducativas no Distrito Federal. Nessa seção serão abordadas questões relativas ao processo de invisibilização e/ou exclusão social vivenciado pelas adolescentes que cometem atos infracionais. Para uma melhor compreensão do fenômeno em questão, será feita uma contextualização histórica da infração juvenil feminina no DF. Por fim, apresentaremos ao leitor um breve histórico do atendimento em Medida Socioeducativa de Internação, desde a inauguração do Centro de Atendimento Juvenil Especializado - CAJE, em Brasília, até os dias atuais. 


\section{Desenvolvimento Humano e Cultura}

A palavra cultura, por seu caráter polissêmico, nos tem remetido a inúmeros significados ao longo do tempo. De origem latina, tem seu significado original ligado às atividades agrícolas, sendo usada, portanto, para designar o cultivo, ou seja, o ato de preparar a terra para que ela produza. Entretanto, o termo assumiu outra conotação a partir da filosofia grega clássica, que passou a entender a cultura como sinônimo de refinamento e sofisticação pessoal, a chamada cultura da alma (Santos, 2010). Foi a partir do século XIX, com a intensificação do poder das nações europeias interessadas em adquirir novos mercados pelo mundo, que as ciências humanas passaram a desenvolver teorias sobre ela e estudá-la mais a fundo. Assim, de acordo com Santos (2010, p. 31), “a moderna preocupação com cultura nasceu associada tanto à necessidade do conhecimento quanto às realidades da dominação política”.

De acordo com Madureira \& Branco (2005), foi somente a partir das duas últimas décadas do século XX que a Psicologia, revendo as suas bases e adotando uma postura crítica e de "fronteira", passou a ativar o diálogo com as outras áreas e a produzir conhecimento científico baseada na ideia de que o individual contém o social e vice-versa. Nesse sentido, abriu-se espaço para a compreensão de que existe uma relação muito próxima entre o sujeito e o mundo social, entre o pensamento e a comunicação, o sentido e o significado, o eu e o outro, ou seja, entre o sujeito, a sociedade e a cultura. Para as autoras citadas, "[a] cultura, portanto, não influencia apenas o desenvolvimento humano: a cultura constitui o sujeito psicológico, marcando de forma profunda o seu desenvolvimento e conferindo-lhe o seu caráter humano" (Madureira \& Branco, 2005, pp. 91-92, grifo no original).

Assim, adotamos para este trabalho a perspectiva de Madureira \& Branco (2012), que definem cultura como:

um sistema aberto que engloba a produção humana e os processos de significação nos seus mais diversos níveis: instrumentos técnicos e tecnológicos, 
estruturas arquitetônicas, produções artísticas, científicas, filosóficas (produtos culturais), processos de construção de significados, crenças e valores (processos culturais). [...] Em nível microanalítico, situa-se nas interações sociais do cotidiano, em um nível macro de análise, considera as ações coletivas e fenômenos históricos como movimentos sociais e políticos (p. 127).

Essa concepção de cultura se mostra relevante para este estudo porque nos permite investigar os processos de desenvolvimento das adolescentes, considerando-se os vários aspectos e características do contexto cultural específico de uma instituição de internação. Neste contexto encontram-se, por um lado, valores, crenças e práticas sociais enraizados que canalizam os processos de significação em determinadas direções, e que tendem a ser transmitidos através das gerações; por outro, acreditamos ser possível promover transformações por meio da ação dos sujeitos e dos grupos sociais envolvidos no processo socioeducativo.

Assim, compreender o fenômeno do desenvolvimento humano a partir de interações sociais situadas em uma realidade sociocultural específica será o tema da nossa próxima subseção. Para tanto, traremos algumas reflexões acerca das contribuições da teoria vigotskiana, especificamente no que se refere à relação entre o sujeito e o contexto sócio-histórico-cultural em que se desenvolve, e ao desenvolvimento das funções mentais superiores.

\section{A contribuição de Vigotski para a Psicologia Cultural.}

Lev Seminovitch Vigotski (1896-1934) é reconhecido como um dos autores que contribuíram para que se compreendesse a relação constitutiva entre os processos psicológicos e a cultura, dando origem a um campo que hoje denominamos psicologia cultural do desenvolvimento. Por meio de seus estudos, procurou esclarecer inúmeras questões que persistiam ao longo do tempo sobre o modo pelo qual o ser humano se constitui como capaz de produzir cultura (Zanella, 2004) e, para isso, trouxe à luz o 
conceito de mediação semiótica. Partindo da ideia marxista de mediação do homem pelo trabalho, Vigotski chegou a duas formas de mediação que afetariam a formação do psiquismo, a que se dá pelos instrumentos e a que se dá pelos signos, a que ele chamou de mediação semiótica (Vigotski, 2011).

Para ele é por meio dessa mediação que se desenvolvem as funções mentais superiores (formas mediadas de comportamento). Isso porque "todas as funções superiores originam-se das relações reais entre indivíduos humanos" (Vigotski, 2011, p. 58), sendo essas profundamente influenciadas pela interação sociocultural em que se encontra o sujeito em desenvolvimento.

A mediação semiótica refere-se à relação indireta entre o sujeito e a realidade criada pelo homem, no processo sócio-histórico-cultural. Essa mediação se dá tanto por meio de objetos físicos (a que ele denomina instrumentos), como por meio dos distintos sistemas de notação, sobretudo a língua. As ações humanas refletem as significações culturais e representam as práticas sociais de um determinado contexto. Ao mesmo tempo, são produtoras potenciais de novas significações que recriam as realidades existentes. Dessa maneira, as duas formas de mediação proporcionam meios para a interpretação e a reinterpretação de um objeto como um novo signo. Do mesmo modo, revelam indicadores dos valores sociais e culturais presentes nesse processo intermitente de significação e ressignificação. O signo, assim, caracteriza-se como ferramenta social de comunicação e interação e, como ferramenta psíquica - usada para potencializar funções psicológicas humanas, como memória e atenção (Toledo, 2014).

Nesse sentido, Vigotski compreende o sujeito como um "agregado de relações sociais encarnadas num indivíduo" (Vigotski, 2000, p. 33, citado em Zanella, 2004). Para Zanella "[...] é a inexorável relação entre sujeito e sociedade. Só há sujeito porque constituído em contextos sociais, os quais, por sua vez, resultam da ação concreta de homens que coletivamente organizam o seu próprio viver (2004, p. 127)" 
Podemos concluir, portanto, que para Vigotski o desenvolvimento humano ocorre a partir das constantes interações com o meio social em que o sujeito se desenvolve, visto que as formas psicológicas mais sofisticadas emergem dessas interações. Assim, o desenvolvimento do psiquismo humano é sempre mediado pelo outro (outras pessoas do grupo cultural), que indica, delimita e atribui significados à realidade (Rego, 2000).

$\mathrm{Na}$ subseção seguinte avançaremos nas reflexões acerca da perspectiva psicológica sociocultural, com foco na relação bidirecional sujeito-cultura.

\section{A Psicologia Cultural: desdobramentos da abordagem de Lev Vigotski.}

A relação bidirecional sujeito-cultura constitui princípio básico da perspectiva psicológica sociocultural (Valsiner, 2012). Nesse sentido, os processos de internalização (da cultura para o sujeito) e de externalização (do sujeito para a cultura) dos signos ocorrem simultaneamente, ou de modo interdependente, caracterizando essa relação bidirecional. De acordo com Madureira \& Branco (2012, p. 127), "O modelo de transmissão cultural bidirecional [...] destaca o papel ativo e transformador do sujeito sobre o seu desenvolvimento e em relação aos contextos estruturados em que se encontra inserido".

Desse modo, para o referencial sociocultural, o sujeito psicológico é um ser ativo e participativo na construção de valores, costumes e modos de pensamento. Desenvolve-se em meio a um conjunto de regras nas quais cresceu e às quais tem acesso, ao mesmo tempo em que assume um importante papel de formador dessas mesmas regras. Complementando a ideia, Senna Pires \& Branco (2008, p. 415) argumentam que:

Ainda que a cultura atue como organizadora dos espaços de construção de significados ao longo do tempo, cada pessoa possui possibilidades e certa 
flexibilidade para conduzir e constituir, de forma intencional e não intencional, os seus processos de internalização e externalização e de ação no mundo.

Enfim, o sujeito psicológico constitui-se pelas interações com os outros e com o seu contexto físico, simbólico e sociocultural, articulando o individual e o coletivo em uma relação bidirecional com o contexto em que se insere (Madureira \& Branco, 2012; Lopes de Oliveira, 2006; Valsiner, 2012; Zittoun, 2009).

Os saberes produzidos sob essa ótica têm contribuído para o crescente entendimento de que o contexto sociocultural no qual o sujeito está inserido tem estreita relação com o seu desenvolvimento. De acordo com Valsiner (2004), o mundo se revela ao sujeito por meio de um reservatório simbólico de linguagens, valores e conceitos e, por meio desse mesmo reservatório simbólico, ele busca dar sentido às diferentes situações experimentadas, integrando-as em uma totalidade psicológica.

O processo intermitente de significação e ressignificação que ocorre no contexto das interações sociais nos leva à reflexão acerca da forma singular com que cada sujeito interpreta (e ressignifica) o mundo à sua volta. Essa forma particular de atribuir significado caracteriza, segundo Valsiner (2012), a sua cultura pessoal, tema a ser abordado na nossa próxima subseção.

\section{A cultura como fenômeno de fronteira.}

Consoante Valsiner (2012), no âmbito da perspectiva psicológica sociocultural do desenvolvimento humano, a cultura pessoal refere-se aos significados pessoais subjetivamente construídos tomando-se por base a matriz cultural maior. A cultura coletiva, por sua vez, refere-se à multiplicidade de mensagens comunicativas, e constitui o input para o desenvolvimento subjetivo. A cultura coletiva é, por natureza, heterogênea, múltipla, diversa. O processo dual de internalização e externalização é fonte de diferenciação entre as culturas pessoal e coletiva, caracterizando o sujeito como 
único, ainda que apoiado sob o mesmo background da cultura coletiva. Nesse sentido, o desenvolvimento humano é um processo de co-construção que envolve tanto o sujeito ativo como o ambiente ativo, e que decorre do encontro entre esses diferentes planos. “[...] enquanto as 'mensagens recebidas' possam ser similares para diferentes indivíduos, o modo pelo qual essas mensagens são transformadas e reconstruídas será de modo necessário pessoalmente único. Culturas pessoais são relativamente autônomas em relação à cultura coletiva" (Valsiner, 2012, p.56). Ainda de acordo com o autor, o processo pelo qual a cultura direciona o desenvolvimento pessoal por meio de sugestões sociais indiretas (implícitas) ou diretas (explícitas), denomina-se canalização cultural.

Sobre o tema da canalização cultural, Yokoy de Souza (2012) esclarece que:

Do ponto de vista sociocultural, o desenvolvimento humano é promovido pela relação dialética entre canalização cultural e papel ativo do sujeito. [...] Por meio de sugestões sociais, que funcionam como circunscritores sobre as possibilidades de comportamento e de percepções do mundo e de si mesmo, determinadas trajetórias são mais favorecidas do que outras. Entretanto, mesmo diante de fortes circunscrições culturais, procura-se, na Psicologia Sociocultural, dar destaque ao papel ativo do sujeito em desenvolvimento (p. 12).

A cultura, desse modo, pode ser compreendida como uma fronteira simbólica "semipermeável" que delimita as diferenças entre os sujeitos e os grupos sociais. Sendo que essas diferenças, assim como as ambiguidades e as tensões, constituem o núcleo dos processos de construção de significados (Madureira \& Branco, 2012; Valsiner, 2012).

A compreensão de que a subjetividade é uma parte da psique do sujeito que sobrevive às tensões e pressões do contexto do qual ele faz parte será o tema da próxima subseção. Um enfoque será dado aos processos narrativos como contexto de desenvolvimento subjetivo. 


\section{O sujeito reflexivo: processos narrativos como contexto de produção de}

subjetividade.

De acordo com os preceitos teóricos da abordagem psicológica sociocultural, o sujeito psicológico é dotado de subjetividade, pois chega a constituir uma consciência reflexiva e intencional, que se desenvolve na interação com o seu contexto sociocultural.

A subjetividade, portanto, não pode ser compreendida fora de um processo ininterrupto de reconstrução de si por meio da reflexão, visto que, por seu caráter dinâmico, é constantemente "esculpida", transformada e reinventada (Zittoun, 2012). Em outras palavras, a subjetividade constitui-se por meio da reflexão e do fluxo de interações sociais. Detém uma natureza dialógica que se desenvolve como resultado do interjogo produzido pelos diálogos internos e diálogos com o/a outro/a, bem como das relações temporais, ou seja, aquelas que advêm da possibilidade de avaliar o passado e antecipar o futuro.

Psicólogos como Jerome Bruner (1991), Theodore Sarbin (1986), e Dan McAdams (2001) defendem a natureza historiada da conduta humana. Para eles, a narrativa é um caminho necessário para a auto-organização e a (re)significação do contexto. Nesse sentido, a narrativa constitui um dos principais cenários em que ocorrem a autorreflexão e a promoção de desenvolvimento humano. Sobre o papel da narrativa na constituição da experiência social, Walter Benjamin relata no seu texto clássico, intitulado O Narrador: considerações sobre a obra de Nikolai Leskov, que "O narrador retira da experiência o que ele conta: sua própria experiência ou a relatada pelos outros. E incorpora as coisas narradas à experiência de seus ouvintes" (Benjamin, 1994, p. 197). Sendo assim, entendemos que a narrativa - de si e do contexto do qual se faz parte - pode contribuir fortemente para o desenvolvimento subjetivo. Consoante Carvalho (2003): 
O auto-relato pode ser tomado como um locus privilegiado do encontro entre a vida íntima do indivíduo e sua inscrição numa história social e cultural. A biografia, ao tornar-se discurso narrado pelo sujeito autor e protagonista, instaura sempre um campo de renegociação e reinvenção identitária (p. 284).

A prática de converter experiência em histórias dá ao narrador um senso de biografia, ou seja, o senso de que se continua a ser o mesmo eu, apesar da dinamicidade dos acontecimentos da vida e das transformações complexas que esses eventos podem provocar. De acordo com Bruner (citado em Lightfoot, 1997) “[...] nós nos tornamos as narrativas autobiográficas que utilizamos para falarmos de nossas vidas" (p. 41).

Nas palavras de Lopes de Oliveira \& Vieira (2006, p. 71): “As narrativas constituem o contexto microgenético em que os sujeitos se apresentam publicamente" e, no contexto das interações discursivas, estratégicas retóricas são aprimoradas de modo a fornecer "[...] suporte narrativo para a constituição de um senso de si, ao mesmo tempo imaginário (apoiado em imagens) e discursivo". Assim, a narrativa pode ser utilizada como uma ferramenta de mediação semiótica que intencionalmente auxilie o sujeito na sua própria (re)organização psíquica, pois “[...] para o adolescente, lembrar significa pensar" (Vigotski, 2011, p. 49), e o ato de lembrar e de narrar pode ajudá-lo/la a reorganizar e a reestruturar suas ideias. Evidencia-se, portanto, a importância da reflexão e da narrativa como ferramentas para a reorganização do curso de vida (Zittoun, 2012), visto que as práticas reflexivas contribuem ainda de modo significativo para o processo de ressignificação de si e do contexto no qual se desenvolve.

Nesse sentido, concordamos com Lopes de Oliveira (2014, no prelo) quando afirma que:

Sendo o psiquismo uma estrutura semioticamente mediada, os signos têm um papel central na configuração psicológica, a qual se expressa e se organiza dialogicamente por meio de histórias. Dito de outro modo, o ser humano é um narrador que vive sua condição humana por meio das narrativas que apresenta, 
nas quais costura sua história pessoal e encadeia a sua existência e a das outras pessoas.

Isso posto, entendemos serem a reflexão e a autorreflexão caminhos possíveis para a transformação de significados, valores culturais, normas e crenças. Compreender o desenvolvimento do/da adolescente como um processo situado histórico-culturalmente é o tema da nossa próxima seção. Para tal enfatizamos, portanto, a mediação dos circunscritores culturais e a agência subjetiva nos processos de desenvolvimento. 


\section{Adolescência(s): processos de desenvolvimento e desafios contemporâneos}

Embora diferentes instituições sociais - saúde, educação, instituições jurídicas, etc.- venham investindo na definição precisa dos marcos etários da adolescência, para efeitos legais no Brasil, de acordo com o art. $2^{\circ}$ do Estatuto da Criança e do Adolescente, considera-se adolescente a pessoa entre 12 e 18 anos incompletos. Levando-se em conta que os objetivos do trabalho em questão visam à garantia de direitos de adolescentes que estão cumprindo medidas socioeducativas, tomamos como referência o que estabelece esse Estatuto.

Interessa-nos compreender a conversão da adolescência em objeto da psicologia e como o campo de estudos da psicologia do desenvolvimento de base sociocultural contribui para a compreensão da adolescência, na contemporaneidade. Para isso, vale resgatar algumas linhas históricas do processo.

Apoiada nos alicerces do modelo médico, a adolescência se tornou objeto de estudo da psicologia ainda no início do século XX, a partir dos estudos de Stanley Hall (1904). Pautada em concepções naturalistas e deterministas, essa fase do ciclo de vida passou a ser caracterizada como um período de turbulências, sofrimentos psicológicos, inquietações e angústias (Tomio \& Facci, 2009; Vieira \& Lopes de Oliveira, 2013).

De um modo geral, o discurso que ainda predomina acerca da adolescência é de que essa é uma fase de extrema emotividade e estresse, onde se alternam estados de excitação, irritação e episódios de depressão. Essa "universalização" das características da adolescência, apoiada nos discursos sociais, encontra subsídio nas vertentes da psicanálise, que contribuem para a disseminação da noção de "crise da adolescência normal" (Toledo, 2014). Desse modo parecem, pois, ignorar a relação entre a condição subjetiva do/da adolescente como um ser ativo, cujas ações e escolhas se dão em interdependência com o contexto social e institucional em que se desenvolve (Vieira \& Lopes de Oliveira, 2013). 


\section{A adolescência na perspectiva Sociocultural.}

Os pressupostos teóricos da Psicologia Sociocultural, contrários à ideia de que esse seria um período igualmente turbulento para todos/as, compreende a adolescência como o uma fase do ciclo de vida que se caracteriza pelo entrelaçamento do amadurecimento físico e psíquico, em que estão envolvidos aspectos biológicos e sociais que não podem ser compreendidos separadamente (Lopes de Oliveira, 2006; Tomio \& Facci, 2009; Vigotski, 2010; Yokoy de Souza, 2013). Nesse sentido, assumimos a perspectiva vigotskiana de que nos tornamos nós mesmos através dos outros. O autor descreve abaixo o desenvolvimento como síntese criativa entre o biológico e o social:

[...] o comportamento do homem é formado pelas peculiaridades e condições biológicas e sociais do seu crescimento. O fator biológico determina a base, o fundamento das reações inatas, e o organismo não tem condição de sair dos limites desse fundamento, sobre o qual se erige um sistema de reações adquiridas. Nesse caso aparece com plena evidência o fato de que esse novo sistema de reações é inteiramente determinado pela estrutura do meio onde cresce e se desenvolve o organismo (Vigotski, 2010, p. 63).

Assim sendo, embora os fatores biológicos sejam universais à espécie, esses são também marcados pela cultura, em que pesam as interações sociais pautadas em questões de gênero, de hierarquias familiares, sociais, entre outros (Lopes de Oliveira, 2006).

Compreendemos, portanto, a adolescência como uma fase do ciclo de vida que, atravessada por diferentes signos sociais - a exemplo de classe social, contexto histórico-cultural, gênero e etnias, não deve ser reconhecida como um fenômeno homogêneo. Assim, sob essa perspectiva, nos seria permitido observar a existência de diversas e distintas "adolescências" (Leite, 2013), marcadas por diferentes dispositivos 
de diferenciação que se necessita considerar com atenção na tentativa de compreender o fenômeno das adolescências contemporâneas.

Isso posto, nosso foco nesse estudo é uma adolescência marcada pela desigualdade social, pelo preconceito - incluem-se aí as desvantagens de gênero - e pela delinquência juvenil. Os temas do gênero e da socioeducação tornam-se o foco de nosso interesse, uma vez a Oficina de Reflexão, intervenção que caracteriza o estudo empírico desta pesquisa, deu-se no módulo feminino de uma unidade de medida socioeducativa de internação.

\section{A relevância das questões de gênero na adolescência.}

Sabemos que são diversas as influências sob as quais a subjetividade se desenvolve. A adolescência é um período em que o acúmulo de experiências e a internalização de valores e significados ao longo do desenvolvimento anterior favorece a diversificação das relações sociais. Essas relações, por sua vez, se estendem cada vez mais para fora do contexto familiar. As novas pautas em que a conduta do adolescente se insere trazem novamente à cena as especificidades das questões de gênero.

O tema gênero caracteriza-se como um campo interdisciplinar, ou seja, um tema transversal que não só pode, mas deve ser enfocado nas diversas subáreas de conhecimento. Embora a Epistemologia Feminista não tenha conseguido constituir uma orientação paradigmática dominante em nenhum campo disciplinar específico, continua a desempenhar importante função política ${ }^{1}$, especialmente no que se refere às reflexões sobre as (des)igualdades de gênero presentes em nossa sociocultura (Lopes de Oliveira \& Madureira, 2014). Todavia, tal como assinalam as autoras, as questões de gênero compõem uma lacuna ainda pouco explorada pela Psicologia - em geral - e pelos estudos de Psicologia do Desenvolvimento, especificamente.

\footnotetext{
${ }^{1}$ Para um aprofundamento teórico sobre os Movimentos Feministas, consultar: Louro (1997) e/ou Toledo (2014).
} 
O fenômeno da desigualdade de gênero no atendimento socioeducativo é complexo e demanda uma abordagem interdisciplinar. Nesse sentido nos apoiamos na ótica proposta por Madureira (2007), Madureira \& Branco (2012) e Lopes de Oliveira \& Madureira (2014), que tem aproximado os estudos de gênero das perspectivas culturais em Psicologia do Desenvolvimento Humano, e de outras autoras como Louro (1997, 2013); Scott (1995); Weeks (2010).

Para as autoras acima, o conceito de gênero é uma construção social, cultural e linguística. Nele está presente a noção de que nos constituímos, como homens e mulheres, também, por meio das mais diversas instituições e práticas sociais, em que se incluem os símbolos, as normas, os conhecimentos, as leis, as doutrinas e as políticas de uma sociedade. Entre as práticas sociais mais importantes para a configuração de gênero na contemporaneidade incluem-se também os meios de comunicação de massa - TV, música, cinema e literatura. "O conceito de gênero enfatiza, assim, a dimensão cultural que apresenta um papel estruturante no processo de tornar-se homem ou mulher" (Madureira \& Branco, 2012, p.138).

Entretanto, nesse processo, Louro (2010) ressalta que os sujeitos não agem apenas como "meros receptores atingidos por instâncias externas e manipulados por estratégias alheias", mas "são participantes ativos na construção de suas identidades" (p.25). Nesse sentido, ao enfatizar o papel ativo do sujeito em seu desenvolvimento, torna-se possível uma aproximação entre os estudos de gênero e a perspectiva psicológica sociocultural.

O conceito de gênero funciona como ferramenta política e analítica que objetiva rejeitar explicações subsidiadas pelas diferenças biológicas ao falar sobre as desigualdades entre homens e mulheres (Madureira \& Branco, 2012). Desigualdades essas que, em nossa matriz sociocultural, implicam em desvantagens para o sexo feminino. Nesse sentido, é possível afirmar que os estudos de gênero criticam de modo veemente o essencialismo biológico. 
De acordo com Scott (1995, citado por Madureira \& Branco, 2012, p. 137), o termo gênero, além de um substituto para o termo mulheres, é também usado para sugerir que qualquer informação sobre as mulheres é necessariamente informação sobre os homens, que um explica o estudo do outro. Ademais, é preciso que se pense o conceito de gênero de forma plural, visto que ele reflete concepções divergentes, não apenas entre as sociedades e os momentos históricos, como também no interior de uma dada sociedade, na qual podemos considerar a existência de diversos grupos - étnicos, religiosos, de classe etc., que exibem sistemas de valores diferenciados e, por vezes, em tensão. Consoante Louro (2010, pp. 11-12), “Os corpos ganham sentido socialmente [...] portanto as identidades sexuais e de gênero (como todas as identidades sociais) têm o caráter fragmentado, instável, histórico e plural, afirmado pelos teóricos e teóricas culturais".

A partir do diálogo entre essas duas perspectivas teórico-metodológicas nos interessa compreender os processos de desenvolvimento psicológico das adolescentes que cometeram atos infracionais e cumprem medida socioeducativa de internação. Para isso, considera-se a relação entre gênero, infração juvenil e a condição de dupla exclusão social a que são submetidas essas adolescentes. É interessante notar que, quando nos referimos a uma situação de dupla exclusão, reportamo-nos aos preconceitos e desigualdades de gênero que reservam às mulheres uma posição de menor valor social. Soma-se a isso o fato de que a sociedade não espera que adolescentes do sexo feminino cometam atos infracionais, especialmente os atos que rompem com os padrões socialmente relacionados às mulheres, como por exemplo, homicídio, latrocínio e/ou tráfico de drogas.

Visando trazer densidade para a fundamentação teórica de nosso estudo, na seção seguinte nos aprofundaremos no tema da infração juvenil feminina. 


\section{A infração juvenil feminina e a proteção integral no atendimento socioeducativo}

Várias são as hipóteses possíveis para a explicação do fenômeno da infração juvenil. Quando se trata da infração juvenil feminina e do complexo conjunto de fatores que a influenciam, não podem ficar de fora questões de gênero que ao longo do tempo vêm influenciando significativamente o processo de invisibilização e/ou de exclusão social que vivenciam cotidianamente as adolescentes que cometem atos infracionais.

Nesse sentido, é importante considerar as questões de gênero e seu papel no desenvolvimento subjetivo das adolescentes. Ramos (2010) aproxima tais questões da realidade das adolescentes que cometem atos infracionais:

A criminalização da pobreza acaba por alargar o espectro dos possíveis “delinquentes" para outros segmentos vulneráveis, como as mulheres, como as jovens, seja pela sedução do tráfico de drogas, seja como uma forma de autoafirmação. A imposição de medidas socioeducativas para as adolescentes autoras de infração tem um lugar seletivo, restrito, simbólico e que reproduz a desigualdade de gênero. Essas medidas restringem direitos e interferem na esfera de liberdade das adolescentes (p.11).

Entretanto, antes de nos aprofundarmos nas questões de gênero que influenciam na compreensão do fenômeno da infração juvenil feminina, convém apresentar ao leitor, mesmo que brevemente, alguns dos dispositivos legais que têm como objetivo promover a proteção integral à criança e ao/à adolescente. Este será, portanto, o tema da nossa próxima subseção.

\section{Adolescentes como sujeitos de direitos.}

$\mathrm{O}$ direito ao atendimento socioeducativo aos/às adolescentes que cometem atos infracionais está previsto no artigo 227 da Constituição da República Federativa do Brasil, promulgada em 1988, e na Lei 8.069 de 1990, também conhecida como Estatuto 
da Criança e do Adolescente- ECA. O referido diploma legal é um conjunto de normas de ordenamento jurídico que tem como objetivo a proteção integral da criança e do adolescente. Por isso regula não só as medidas de proteção como também prevê as Medidas Socioeducativas (que são os meios pelos quais a justiça responsabiliza os/as adolescentes que cometem atos infracionais ${ }^{2}$ ). Lopes de Oliveira, sobre o Estatuto da Criança e do Adolescente esclarece que (2014, p. 80):

A referida lei está dividida em duas partes, uma que prioriza os direitos de crianças e adolescentes e dos casos em que estes são violados (Livro I e parte do Livro II); e outra, que trata das circunstâncias em que crianças e adolescentes são autores de violência (a partir do título 3 do Livro II). O princípio filosófico e jurídico da proteção está claramente resumido no Artigo 5 do ECA, que assinala: "Nenhuma criança ou adolescente será objeto de qualquer forma de negligência, discriminação, exploração, violência, crueldade e opressão, punido na foram da lei qualquer atentado, por ação ou omissão, de seus direitos fundamentais.

Entretanto, apesar da afirmação do paradigma da proteção integral, o ECA não versa sobre as diretrizes político-pedagógicas da execução das medidas socioeducativas. Desse modo, visando dar concretude aos avanços da legislação, foi publicada, em 2006, a Resolução $n^{0}$ 119/2006 do Conselho Nacional dos Direitos da Criança e do Adolescente - CONANDA ${ }^{3}$. Amparada no Sistema de Garantia de Direitos ${ }^{4}$, constituise como um documento referencial de diretrizes para a execução das medidas socioeducativas e para o funcionamento dos programas e/ou unidades de atendimento

${ }^{2}$ O ECA especifica como ato infracional apenas "a conduta descrita como crime ou contravenção penal” (ECA, p.23, Art. 103).

\footnotetext{
${ }^{3}$ A Resolução 119/2006 do CONANDA foi elaborada por meio de uma parceria entre a Secretaria Especial de Direitos Humanos - SEDH, a Subsecretaria de Promoção dos Direitos da Criança e do Adolescente - SPDCA, o Conselho Nacional dos Direitos da Criança e do Adolescente - CONANDA, com o apoio do Fundo das Nações Unidas para a Infância- UNICEF.

${ }^{4}$ O Sistema de Garantia de Direitos tem como objetivo promover a proteção integral à criança e ao/à adolescente. Nele estão contempladas as ações promovidas pelos três poderes (Executivo, legislativo e Judiciário), pelo Poder Público em suas três esferas (União, estados, DF e municípios) e pela sociedade civil.
} 
socioeducativo. A partir dessa Resolução foi instituído o Sistema Nacional de Atendimento Socioeducativo - SINASE, sancionado pela lei 12.594/2012.

Cabe destaque ao fato de que, na Resolução no 119 do CONANDA, dentre suas recomendações ao atendimento socioeducativo, há um conjunto de diretrizes pedagógicas pautadas nos direitos humanos. Nesse sentido, questões de gênero, diversidade cultural, igualdade étnico-racial e orientação sexual devem constar nos fundamentos teórico-metodológicos dos projetos pedagógicos das unidades e/ou programas que executam as MSE.

Entretanto, ainda são poucos os estudos e as pesquisas, sobre as adolescentes que cometem atos infracionais, que possam auxiliar no planejamento e no desenvolvimento dessas intervenções pedagógicas. Nesse sentido, torna-se ímpar investigar quem são e o que pensam, sobre o atendimento socioeducativo, essas adolescentes, tema que será explorado nas próximas subseções.

\section{Quem são as adolescentes que cumprem MSE no Brasil?}

Segundo dados do Levantamento Nacional do Atendimento Socioeducativo ao Adolescente em Conflito $^{5}$ com a Lei, no ano de 2011 havia 89.250 adolescentes em cumprimento de medidas socioeducativas, no Brasil, incluindo-se aí medidas em meio aberto e meio fechado ${ }^{6}$. Esse mesmo levantamento aponta que, entre 2010 e 2011, houve um crescimento de mais de $10 \%$ na aplicação das medidas restritivas e privativas de liberdade - internação estrita, internação provisória e semiliberdade, sendo que o

\footnotetext{
${ }^{5} \mathrm{O}$ referido documento ressalta a necessidade de discussões mais aprofundadas sobre as razões que levaram ao expressivo aumento do número de adolescentes sentenciados à MSE de Internação no Brasil. Nesse sentido, os órgãos de articulação interinstitucional são responsáveis pela proposição de estratégias articuladas de intervenção que visem à reversão desse quadro no Sistema Socioeducativo brasileiro.
}

\footnotetext{
${ }^{6}$ As MSE em Meio Aberto são: Advertência, Obrigação de Reparar o Dano, Prestação de Serviços à Comunidade e Liberdade Assistida (ECA, 2002, p.23). Já as MSE em Meio Fechado são: Inserção em Regime de Semiliberdade e Internação em Estabelecimento Educacional - Internação Estrita (ECA, 2002, p. 23).
} 
Distrito Federal ocupa o segundo lugar entre os estados brasileiros com a maior taxa de adolescentes em privação de liberdade. O referido documento acrescenta, ainda, que dentre os indicadores que podem contribuir para esse aumento, destacam-se: a oferta de vagas de internação em decorrência da construção de novas unidades de atendimento socioeducativo, indícios de uma cultura de institucionalização presente no judiciário, a exposição da população adolescente a territórios que concentram indicadores de violência e também a expansão do crack junto à população adolescente.

No que se refere ao percentual nacional de adolescentes em cumprimento de MSE privativas e restritivas de liberdade, o público feminino representa 5\% do total. Já nas MSE em Meio Aberto, essa proporcionalidade sobe para $12 \%$ do total ${ }^{7}$. No cenário do atendimento socioeducativo no Distrito Federal, o percentual de adolescentes em cumprimento de medidas socioeducativas restritivas de liberdade aproxima-se da média nacional, ou seja, 5\% são do sexo feminino e 95\% são de sexo masculino (Brasil, 2011a, CODEPLAN, 2013).

Em 2013, Camargo, Marinho, Santos, Gutierres \& Galinkin realizaram uma pesquisa sobre as adolescentes atendidas no SSE do Distrito Federal, considerando o período de 2004 a 2011. Após a análise de 404 relatórios elaborados por profissionais do sistema socioeducativo foi possível traçar um perfil dessas adolescentes, que são sintetizados a seguir.

Os dados revelaram que $64,9 \%$ das adolescentes haviam sido apreendidas por tráfico de drogas e/ou pela prática de roubo ou furto. Quanto ao local de residência, apenas 1\% delas residia em Brasília (Plano Piloto - Cruzeiro, Sudoeste/Octogonal, Noroeste e Candangolândia), ao passo que mais de 50\% residiam em quatro Regiões Administrativas do DF: Ceilândia, Planaltina, Samambaia e Recanto das Emas. Quanto à composição familiar, 29,7\% das adolescentes vinham de famílias monoparentais,

${ }^{7} \mathrm{O}$ documento não especifica a porcentagem total de meninas e meninos em cumprimento de MSE em Meio Aberto. Para esse cálculo foram somados o número de adolescentes, por sexo, em cumprimento de MSE de Liberdade Assistida e o número de adolescentes em cumprimento de MSE de Prestação de Serviços à Comunidade. A partir desses dados foi possível chegar ao percentual apresentado. 
sendo que a grande maioria delas residia com a mãe. Já 20,4\% das adolescentes residiam ou em abrigos, ou com amigos e/ou amigas, ou nas ruas ou sozinhas. No que se refere à escolarização, $65,1 \%$ das adolescentes não frequentavam a escola no momento da apreensão, e a maioria ainda cursava o Ensino Fundamental.

Dados mais recentes obtidos junto à Central de Vagas da Subsecretaria do Sistema Socioeducativo - SUBSIS revelam que em setembro de 2014 havia no Distrito Federal 3375 adolescentes (de ambos os sexos) em internação provisória e em efetivo cumprimento de medida socioeducativa. Desse total, eram 11 as adolescentes que estavam em Internação Provisória ${ }^{8}$ e 18, em cumprimento de MSE de Internação Estrita. Das adolescentes sentenciadas à Medida Socioeducativa de Internação Estrita $(n=18)$, sete respondiam por ato infracional análogo ao crime de homicídio, previsto no Art. 121 do Código Penal Brasileiro; duas respondiam por ato infracional análogo ao crime previsto no Art. $157 \S 3^{\circ}$ do referido diploma legal - roubo seguido de morte da vítima; quatro respondiam por ato infracional análogo ao crime de tráfico de drogas, previsto no Art. 33 da Lei 11.343/06 - Lei de Tóxicos e apenas uma respondia pelo ato infracional análogo ao crime de porte ilegal de arma de fogo, previsto no Art. 14 da Lei 10826/03 Lei que dispõe sobre registro, posse e comercialização de arma de fogo.

Tabela 1. Dados estatísticos de adolescentes em cumprimento de MSE de Internação Estrita e tipo de ato infracional cometido.

\begin{tabular}{|c|c|r|}
\hline \multicolumn{3}{|c|}{ ATOS INFRACIONAIS - INTERNAÇÃO ESTRITA } \\
\hline \multirow{2}{*}{ HOMICÍDIO (TENTADO E/OU CONSUMADO) } & HOMENS & 141 \\
\cline { 2 - 3 } & MULHERES & 7 \\
\hline \multirow{2}{*}{ LATROCÍNIO (TENTADO E/OU CONSUMADO) } & HOMENS & 59 \\
\cline { 2 - 3 } & MULHERES & 2 \\
\hline
\end{tabular}

\footnotetext{
${ }^{8}$ A internação provisória não é considerada medida socioeducativa, visto que não depende da sentença judicial, pois o/a adolescente ainda está em processo de investigação quanto à autoria (ou não) de ato infracional.
} 


\begin{tabular}{|c|c|r|}
\hline ROUBO (TENTADO E/OU CONSUMADO) & HOMENS & 279 \\
\cline { 2 - 3 } & MULHERES & 4 \\
\hline \multirow{2}{*}{ TRÁFICO DE DROGAS } & HOMENS & 48 \\
\cline { 2 - 3 } & MULHERES & 4 \\
\hline \multirow{2}{*}{ PORTE DE ARMA DE FOGO } & HOMENS & 35 \\
\cline { 2 - 3 } & MULHERES & 1 \\
\hline \multirow{2}{*}{ RECEPTAÇÃO/FURTO } & HOMENS & 33 \\
\cline { 2 - 3 } & MULHERES & 0 \\
\hline \multirow{2}{*}{ OUTROS } & HOMENS & 37 \\
\cline { 2 - 3 } & MULHERES & 0 \\
\hline
\end{tabular}

Quanto aos dados estatísticos e/ou informações sobre as adolescentes em cumprimento de MSE de Semiliberdade, foi possível o acesso apenas ao quantitativo (n $=106$ ) de adolescentes de ambos os sexos que cumpriam essa MSE. Desses, 11 eram do sexo feminino e 95 do sexo masculino.

Em relação às adolescentes que estavam em cumprimento de MSE em Meio Aberto, no Distrito Federal, a Subsecretaria do Sistema Socioeducativo - SUBSIS nos disponibilizou apenas o número total de adolescentes, atualmente cadastrados $(\mathrm{n}=$ 2387), sem distinção de gênero.

Tabela 2. Dados estatísticos de adolescentes em internação provisória e em cumprimento de MSE no Distrito Federal.

\begin{tabular}{|c|c|c|}
\hline \multicolumn{3}{|c|}{ CÚMERO DE ADOLESCENTES EM INTERNAÇÃO PROVISÓRIA E EM EFETIVO } \\
CUMPIMENTO DE MSE \\
\hline \multirow{2}{*}{ INTERNAÇÃO SANÇÃO } & HOMENS & 12 \\
\hline \multirow{2}{*}{ INTERNAÇÃO PROVISÓRIA } & HOMENS & 209 \\
\cline { 2 - 4 } & MULHERES & 11 \\
\cline { 2 - 3 } & SUBTOTAL & 220 \\
\hline
\end{tabular}




\begin{tabular}{|c|c|c|}
\hline \multirow{2}{*}{$\begin{array}{c}\text { INTERNAÇÃO } \\
\text { (SENTENCIADOS) }\end{array}$} & HOMENS & 632 \\
\cline { 2 - 3 } & MULHERES & 18 \\
\cline { 2 - 3 } & SUBTOTAL & 650 \\
\hline \multirow{2}{*}{ SEMILIBERDADE } & HOMENS & 95 \\
\cline { 2 - 4 } & MULHERES & 11 \\
\cline { 2 - 3 } & SUBTOTAL & 106 \\
\hline \multirow{2}{*}{$\begin{array}{c}\text { LIBERDADE ASSISTIDA E } \\
\text { PRESTAÇÃO DE SERVIÇO À } \\
\text { COMUNIDADE }\end{array}$} & $\begin{array}{c}\text { HOMENS E } \\
\text { MULHERES }\end{array}$ & 2387 \\
\hline \multicolumn{2}{|c}{ TOTAL GERAL } & $\mathbf{3 3 7 5}$ \\
\hline
\end{tabular}

Diante dos dados apresentados, é possível concordar, ainda mais, com Assis \& Constantino (2001), quando afirmam que a situação das adolescentes envolvidas em delitos permanece em desatenção até os dias atuais. Segundo as pesquisadoras, inúmeros fatores têm contribuindo para a invisibilização da infração feminina e a consequente exclusão social das adolescentes autoras de infração. Dentre eles, destacam-se "a sua reduzida incidência - se comparada à masculina, o papel secundário da mulher na sociedade, o preconceito que atribui pouco ou nenhum valor às manifestações de desajuste social da mulher e também a falta de pressão da opinião pública, que não se interessa pelo tema" (p. 20).

O tema do processo histórico e cultural de invisibilização da infração juvenil feminina, especificamente no Distrito Federal, será resgatado na subseção seguinte.

Para isso, discorreremos sobre construção social dos delitos, especificamente aqueles que, aos olhos do poder judiciário, eram rotulados como "delitos tipicamente femininos" (Brito, 2007). Também sobre a naturalização desses delitos que, fundamentados na perspectiva da Criminologia Positivista, se mostrava uma prática comum, entre as décadas de 1960 e 1980, no Distrito Federal. 


\section{A infração juvenil feminina no DF: uma breve contextualização histórica.}

A historiadora Eleonora Zicari Brito (2007) investigou a questão da infração feminina, no DF. Ela pôde observar, a partir da análise de mais de cinco mil processos que tramitaram na Vara da Infância e Juventude de Brasília ${ }^{9}$ (antigo Juizado de Menores) entre as décadas de 1960 e o final dos anos 1990, um estreitamento do olhar da Justiça de menores sobre as práticas delituosas femininas. "Esse olhar diferenciado conferia ao fenômeno do desvio infanto-juvenil um caráter majoritariamente masculino" (Brito, 2007, p. 158, grifo no original). Acrescenta Brito que, durante esse período, o sistema de justiça juvenil colaborou com um "universo representacional" que tendia a reproduzir as representações dominantes, reservando as atuações masculina e feminina aos espaços público e privado, respectivamente.

De acordo com a mesma pesquisadora, os dados do DF evidenciam que, ao longo dessas quatro décadas, a infração feminina apresentou maior índice de processos abertos na rubrica roubos/furtos ${ }^{10}$ de objetos. Esses furtos eram com frequência praticados no ambiente de trabalho por meninas e moças empregadas como domésticas. Entretanto, a pesquisa chama a atenção para o fato de que, no desenrolar dos processos, muitas vezes, descobria-se que a acusação representava uma estratégia para resolver um problema muito comum, principalmente nos anos 1960 e 1970 e persistente com menor ênfase nas outras décadas: livrar-se da responsabilidade sobre meninas que, trazidas do interior para servirem de empregadas domésticas, requeriam mais liberdade, ou mesmo fugiam ao controle. Por meio do processo, podiam transferir para o Estado a tutela daquelas adolescentes que se tornavam um "problema" sob a perspectiva das patroas.

Entretanto, eram comuns pareceres favoráveis às acusadas ou o arquivamento do processo. Isso porque, na maioria das vezes, elas justificavam seus furtos como um mero "ajuste de contas" com seus patrões, uma vez que, com frequência, não recebiam

\footnotetext{
${ }^{9}$ Em 2012 passou a se chamar Vara da Infância e Juventude do Distrito Federal.

${ }^{10}$ A autora esclarece que os processos analisados apresentavam uma especificação imprecisa quanto ao ato praticado. Assim, a equipe de pesquisa optou por incluir as modalidades furto e roubo em uma única categoria.
} 
remuneração financeira regular pelo trabalho doméstico realizado. De toda forma, notase que era dada pouca importância a esses tipos de delitos. Aos olhos da justiça, essas eram "práticas destituídas de legitimidade, ou, ainda, um assunto que não lhe dizia respeito" (Brito, 2007, p.168), que deveria ser tratado, portanto, no âmbito privado.

Nas décadas de 1970 e 1980, outro estilo de roubos/furtos passa a ocorrer com mais frequência entre as adolescentes: $\mathrm{O}$ furto de objetos em lojas de departamento. Muito embora essa prática fugisse ao clássico perfil dos atos praticados por meninas (por serem furtos praticados fora do espaço privado), a justiça os interpretava como "uma desviança feminina socialmente esperada" (Brito, 2007, p.176). Isso porque não se relacionavam à necessidade e se configuravam como furto de objetos relacionados à mera satisfação da vaidade feminina (maquiagens, bijuterias, roupas, etc.) devendo, portanto, ser também "deixada de fora do âmbito do sistema penal formal" (Brito, 2007, p.176).

Entretanto, embora essa prática delituosa não estivesse restrita apenas às adolescentes pobres, apenas essas eram levadas a responder, perante a justiça, por seus atos. Fato que nos leva a outro fenômeno: a criminalização da pobreza. Na perspectiva da Justiça de Menores de Brasília, muitos desses desvios justificavam-se pela pobreza das transgressoras, fomentando o imaginário social que (ainda hoje) associa a pobreza à delinquência. Conforme denunciam os processos analisados, o olhar descriminalizador (tanto da justiça como da sociedade) voltava-se apenas para as adolescentes de classes sociais mais altas. Com um olhar claramente preconceituoso, essa criminalização da adolescente pobre instituía um modelo de transgressão feminina com consequências pautadas, quase que exclusivamente, no poder econômico de suas famílias.

Nessas mesmas décadas, outro tema relevante para a compreensão da infração feminina foram os processos relativos à inadaptação familiar de crianças e adolescentes do sexo feminino, que também passaram a representar números expressivos. Normalmente abertos a partir de denúncias feitas pelos próprios pais e/ou responsáveis, 
frente a atos considerados desrespeitosos à família como desobediências, más-criações, descumprimento de normas familiares etc. Esses casos mostravam que também a “família funcionava como partícipe na construção de certos desvios” (p.184).

Entretanto, a partir da segunda metade da década de 1980, essas denúncias perderam força, desaparecendo por completo no final da década. Esse desaparecimento de processos com essa rubrica é um dado interessante para refletirmos sobre o quanto as crenças e os valores sociais influenciam as decisões judiciais.

Sob essa perspectiva, torna-se ainda mais relevante considerar a importância dos movimentos feministas, os quais tiveram influência direta e indireta nos valores e as práticas sociais que envolvem mulheres de todas as idades. No Brasil, especificamente, foi a partir do ano de 1980 que esses movimentos - após anos de reivindicações conseguiram finalmente contribuir positivamente para algumas transformações e mudanças necessárias na legislação do nosso país, que hoje reconhece a mulher como cidadã, portanto, plena de direitos.

No que se refere aos crimes de maior potencial ofensivo, como homicídio e tentativa de homicídio, estes estavam muitas vezes relacionados à prática da prostituição. Não raramente as acusadas eram inocentadas, dados "os padrões instituídos como desvios próprios ao mundo da prostituição feminina” (p.207). A imagem da "prostituta nata" foi, durante muito tempo, utilizada pelos juristas como justificativa para o arquivamento de inúmeros processos. Buscando fundamentos na criminologia positivista (Baratta, 1999, 2013), eles interpretavam o comportamento "desviante" como um fenômeno eminentemente individual, ou seja, como parte da própria "natureza" do sujeito. Nesse sentido, acreditavam existir uma explicação psicofisiológica para a prostituição. Nesse período, segundo a autora, tornou-se mais expressiva a ocorrência de homicídios femininos. Entretanto, a maior parte desses processos acabou arquivada. 
Percebe-se que era usual a desatenção da Justiça de Menores em relação às meninas que se encontravam em situação de risco, o que incluía aquelas que se prostituíam ou viviam em lares conflituosos, por exemplo. Adotando-se uma perspectiva naturalizante do fenômeno, se "admitia não só a inevitabilidade desses comportamentos 'fora da norma', mas, ainda, a necessidade de se conviver com eles" (Brito, 2007, p. 207).

Ademais, nos casos em que as práticas estavam "em desacordo com o que se poderia considerar 'normal', mesmo entre as mulheres que transgridem, [...] era evidente a falta de preparo das autoridades 'competentes' para lidar com algo que as normas de gênero faziam parecer tão antinatural” (p. 235). Como consequência do despreparo, era comum a Medida de Recambiamento, ou seja, a transferência dessas adolescentes para outras cidades, onde ficariam sob a vigilância de parentes que se dispunham a ajudar.

Após esse breve histórico, podemos perceber que antes da implementação do Estatuto da Criança e do Adolescente ${ }^{11}$, a justiça juvenil era discricionária, sendo que o “comportamento desviante" das jovens era julgado tendo como principais critérios o espírito de cada época, na forma de valores sobre o sexo, a classe socioeconômica, os comportamentos socialmente esperados e, como vimos em alguns casos, a "natureza humana da mulher". Assim, era comum a "construção social do delito" (Brito, 2007, pp. 183-184) que, ao naturalizar comportamentos, definia quais seriam aqueles socialmente aceitos e, portanto, passíveis (ou não) de perdão judicial.

É interessante notar que, ao longo da história, a infração juvenil feminina passou por um forte crivo social. Apoiado na criminologia positivista ${ }^{12}$ e também fundamentado em valores patriarcais, essa peneira social legitimou estereótipos e fomentou preconceitos de gênero, classe social e etnia que, infelizmente, persistem até

\footnotetext{
${ }^{11}$ Imediatamente anterior ao ECA, vigorava o Código de menores de 1927, também conhecido como 'Código de Mello Mattos'. Esse foi o nome dado ao decreto 17. 943-A, de 12-10-1927, em uma homenagem a seu autor, o jurista José Candido de Albuquerque Mello Mattos, $1^{\circ}$ juiz de Menores do Brasil.

${ }^{12}$ Para um aprofundamento teórico sobre Criminologia Positivista, ver: Mendes, 2014; Baratta, 2013.
} 
hoje. Alguns desses preconceitos de gênero podem ser percebidos no sistema socioeducativo do DF, seja pela precariedade de políticas de atendimento às adolescentes que cometem ato infracional, seja por meio da violência institucional que reproduz cotidianamente elementos do patriarcado $^{13}$ e do machismo presentes em nossa sociocultura (Ramos, 2010; Silvério, 2008).

Consequentemente, muitos anos se passaram sem que fosse dada a devida atenção ao fenômeno. As dificuldades pelas quais ainda passa o Sistema Socioeducativo no DF, sobretudo no atendimento às adolescentes em cumprimento de medidas socioeducativas, retratam essa realidade. Na subseção a seguir apresentaremos uma breve contextualização histórica do atendimento socioeducativo às adolescentes no Distrito Federal. Nossa intenção com essa contextualização é situar o leitor frente às transformações (geralmente cercadas de inúmeras dificuldades) pelas quais passou o Sistema Socioeducativo do DF, nas últimas duas décadas. Considerando que a pesquisa foi desenvolvida com adolescentes do sexo feminino que à época cumpriam MSE de Internação ${ }^{14}$, colocaremos o foco sobre essa modalidade de Medida Socioeducativa (MSE).

\section{A MSE de Internação: histórico do atendimento no Distrito Federal.}

Face à escassez de pesquisas na área e à dificuldade em se obter informações sobre o atendimento socioeducativo às adolescentes no Distrito Federal, optamos por iniciar esse percurso histórico a partir da inauguração do Centro de Atendimento Juvenil

\footnotetext{
${ }^{13}$ Para um aprofundamento teórico sobre o Patriarcado (e Patriarcado Contemporâneo), ver: Fávero (2010); Mendes, 2014.

${ }^{14}$ A pesquisa em questão foi realizada em duas unidades de internação, a saber: Unidade de Internação do Recanto das Emas - UNIRE e Unidade de Internação de Santa Maria - UISM. Uma descrição mais detalhada de cada uma delas será apresentada, na forma de crônica, no capítulo de Metodologia.
} 
Especializado - CAJE, posteriormente rebatizado de Unidade de Internação do Plano Piloto (UIPP ${ }^{15}$ ), em 2012, pouco antes de sua desativação.

É interessante ressaltar que, visando cumprir determinações estabelecidas no Estatuto da Criança e do Adolescente - ECA, na Lei do SINASE e na Resolução 119/2006 do CONANDA, sobre o atendimento socioeducativo, desde o ano de 2003 foram inauguradas sete novas Unidades no Distrito Federal. A abertura dessas novas unidades possibilitou que se iniciasse uma reestruturação no atendimento socioeducativo no Distrito Federal, especialmente no que se refere aos parâmetros arquitetônicos das unidades - número de adolescentes por unidade - e aos parâmetros de gestão pedagógica no atendimento - objetivando assegurar o atendimento adequado à garantia dos direitos fundamentais dos/das adolescentes.

Apresentamos, a seguir, algumas informações sobre as unidades de MSE de Internação e de Internação Provisória do DF.

\section{O Centro de Atendimento Juvenil Especializado - CAJE (UIPP).}

O Centro de Atendimento Juvenil Especializado - CAJE foi inaugurado em 1994, com base na Lei 663 de $1994^{16}$, que extinguiu o Centro de Reclusão de Adolescentes - CERE, unidade que até então acautelava adolescentes em cumprimento de internação provisória e de Medida Socioeducativa de Internação. Essa mudança se deu em virtude do processo da implementação do Estatuto da Criança e do Adolescente - ECA. Assim, orientado pelo paradigma da proteção e dos direitos humanos, o atendimento socioeducativo passou por um reordenamento. Entretanto, apesar dos esforços para essa reestruturação, o espaço físico considerado inadequado para o atendimento aos/às adolescentes em cumprimento de MSE de Internação foi um grande

\footnotetext{
${ }^{15}$ A mudança de nome foi parte de uma medida de reestruturação do Sistema Socioeducativo do DF, proposta pela Secretaria da Criança do DF.
}

\footnotetext{
${ }^{16}$ Lei n ${ }^{0}$ 663, de 28 de janeiro de 1994, DODF de 31/01/1994 - Dispõe sobre a criação do Centro de Atendimento Juvenil Especializado na Fundação do Serviço Social do Distrito Federal.
} 
empecilho para a plena reestruturação. O local, construído segundo uma lógica repressiva e punitiva, típica do paradigma menorista, não favorecia a concretização de projetos de intervenção pedagógica. Os principais problemas arquitetônicos identificados foram: quartos pequenos com portas de ferro e trancas, caracterizando verdadeiras celas, espaços físicos insalubres, com pouca ventilação, sem higienização e iluminação adequada e a inexistência de espaços de socialização (refeitórios, quadras de esportes, etc.) entre os adolescentes.

Com a finalidade de tornar esse espaço físico adequado para as novas prerrogativas da execução da MSE de Internação, em 1995 foram construídas novas alas dentro da Unidade. Mas essas adaptações não foram suficientes para adequar o CAJE aos parâmetros do ECA. Assim, pouco a pouco o CAJE foi se transformando numa edificação constituída, basicamente, de puxadinhos. Segundo o Relatório da Comissão Especial do Conselho de Defesa dos Direitos da Pessoa Humana, de 2004, mesmo após inúmeras reformas, a estrutura física da unidade permanecia inteiramente desvinculada dos objetivos propostos pelo Estatuto da Criança e do Adolescente - ECA. A estrutura das edificações, constituída de paredes pré-moldadas de fácil destruição, possibilitava a retirada de vergalhões e espetos de ferro. Os pátios, localizados dentro dos próprios módulos, não dispunham de uma estrutura adequada para a prática de exercícios e/ou para os momentos de interação, visto que o chão era o único local de acomodação durante o banho de sol. O espaço reservado para a escola não tinha salas em número suficiente para atender todos os alunos. Também não havia um refeitório, o que obrigava os/as adolescentes a comerem dentro dos próprios quartos, sentados nas camas ou no chão (Relatório da Comissão Especial do Conselho de Defesa dos Direitos da Pessoa Humana, 2004).

Desse modo, na medida em que novas alas eram construídas, piores eram as condições de acautelamento e mais grave se tornava o quadro de superlotação na Unidade. Com capacidade para receber 165 adolescentes, já chegou a acautelar 
aproximadamente 500 de uma vez. Com isso, os problemas de saúde, como dermatoses e doenças infectocontagiosas tornavam-se cada vez mais frequentes.

É importante chamar atenção para o fato de que quando nos referimos à "superlotação" das unidades de MSE de Internação, o problema não se restringe ao espaço físico, mas refere-se à precarização de todo o atendimento a que tem direito o/a adolescente, o que inclui Saúde, Educação/Escolarização, Esporte, Cultura, Lazer, Profissionalização e atendimento com equipe profissional especializada - Assistente Social, Pedagogo e Psicólogo.

Conforme informações obtidas entre os anos de 2003 e 2014 junto a diversos educadores sociais que atuaram no CAJE (e antes no CERE), ao longo dos mais de 20 anos de funcionamento da unidade muitas foram as tentativas de implementação de um modelo de atendimento orientado por princípios pedagógicos e humanizados. Embora buscando se pautar no paradigma da proteção integral, o Sistema Socioeducativo do DF ainda permanecia referenciado no antigo modelo tutelar, sendo o CAJE, especificamente, palco de reiteradas práticas de violação dos direitos dos/das adolescentes. Dentre as várias dificuldades com as quais se deparavam os educadores sociais (superlotação, escassez de políticas de prevenção à infração, pouco investimento em MSE de Meio Aberto, rápido crescimento da cidade e da violência urbana, entre outras), provavelmente a inadequação do espaço físico, o modelo de atendimento correcional-repressivo e o número insuficiente de profissionais para atender aos/às adolescentes em internação provisória e em cumprimento de MSE de Internação foram as que mais inviabilizaram e comprometeram o processo socioeducativo ao longo dos anos.

O CAJE funcionou, durante todos esses anos, em condições extremamente precárias, insalubres e desumanas (Relatório de Inspeção Nacional às Unidades de Internação de Adolescentes em Conflito com a Lei, OAB e CFP, 2006) ${ }^{17}$. O quadro de

\footnotetext{
${ }^{17}$ Relatório de visitas realizadas simultaneamente em 22 estados brasileiros e no Distrito federal, em 15 de março de 2006.
} 
superlotação foi uma constante. Desse modo, após longos anos de denúncias aos órgãos de defesa da criança e do adolescente, bem como de denúncias de violação dos direitos desses adolescentes por importantes meios de comunicação brasileiros, o Governo do Distrito Federal, em março de 2013, finalmente desativou essa unidade de internação. Com isso, encerrou-se o ciclo de uma instituição que acumulou, ao longo de 38 anos, mais de 30 mortes e incontáveis rebeliões.

\section{O Centro Socioeducativo Amigoniano - CESAMI (UIPSS).}

Até o ano de 2003 o CAJE era a única unidade de internação no Distrito Federal, quando foi então inaugurado o CESAMI (localizado na fazenda da Papuda, em área próxima ao presídio homônimo). Essa unidade foi criada com o objetivo de acautelar adolescentes do sexo masculino durante a internação provisória. Entretanto, sua estrutura arquitetônica segue os mesmos padrões dos presídios, visto que foi construída para receber presos adultos. Com espaço para atender até 120 adolescentes, em pouco tempo se tornou insuficiente para a demanda, e o CAJE passou, novamente, a receber (também) esses adolescentes. Em setembro de 2013 foi inaugurada uma nova ala com capacidade para atender 60 adolescentes. Assim, conforme consta na portaria $\mathrm{n}^{\mathrm{o}} 311$ publicada no DODF de 15 de outubro de 2013, o CESAMI ampliou o número de vagas para 180 adolescentes.

Desde a sua inauguração até o final do ano de 2013 o CESAMI teve a sua gestão compartilhada entre o GDF e a Congregação dos Religiosos Terciários Capuchinhos de Nossa Senhora das Dores - os Amigonianos. Essa parceria tinha como objetivo construir um Projeto Político Pedagógico Institucional pautado em uma proposta interventiva pedagógica - terapêutica orientada pelos princípios amigonianos ${ }^{18}$. Esses princípios preconizavam, sobretudo, um tratamento digno para os jovens acautelados. Após 10 anos de parceria, o GDF assumiu (em janeiro de 2014) integralmente a gestão

\footnotetext{
${ }^{18}$ Relatório Institucional do Projeto Político Pedagógico Institucional do Centro Socioeducativo Amigoniano, disponível em: elkinpaezch.files.wordpress.com
} 
da unidade que, a partir de então, passou a se chamar Unidade de Internação Provisória de São Sebastião - UIPSS.

\section{O Centro de Internação de Adolescentes Granja das Oliveiras - CIAGO (UNIRE).}

Em 2006 foi inaugurado o CIAGO (localizado na Região Administrativa do Recanto das Emas - DF). Com capacidade para atender 144 adolescentes, passou a dividir com o CAJE a execução da MSE de Internação. Assim como o CESAMI, o CIAGO iniciou suas atividades sob a responsabilidade dos amigonianos, permanecendo assim até o ano de 2008.

De 2008 a 2010 a unidade ficou sob a responsabilidade de outra organização não governamental, o IDP - Instituto de Desenvolvimento Profissional. A partir de 2010 (após sucessivos convênios e contratos com entidades não governamentais) o GDF assumiu integralmente sua gestão, e a unidade passou a se chamar UNIRE - Unidade de Internação do Recanto das Emas. Cabe destaque ao fato de que, assim como a UIPSS, a UNIRE também passou por reformas de ampliação do espaço, e atualmente tem $180^{19}$ vagas.

O Centro de Internação de Adolescentes de Planaltina - CIAP (UIP).

Dois anos depois da inauguração do CIAGO, em 2008, foi inaugurado o CIAP (localizado na Região Administrativa de Planaltina-DF), também destinado a receber adolescentes do sexo masculino em cumprimento de MSE de Internação. Com a inauguração dessa Unidade, foram abertas mais 80 vagas para o cumprimento de MSE de Internação no DF.

Diferentemente do CIAGO e do CESAMI, essa unidade vem sendo gerida, desde a sua inauguração, apenas pelo GDF. Atualmente ela recebe o nome de Unidade de Internação de Planaltina - UIP.

\footnotetext{
${ }^{19}$ Foi publicado no DODF de 15 de outubro de 2013 o número de vagas em todas as unidades de MSE do DF.
} 


\section{A Unidade de Internação de Saída Sistemática - UNISS.}

Em janeiro de 2014 foi inaugurada, em área contígua à UNIRE (na R.A. do Recanto das Emas), uma unidade que passaria a atender os adolescentes do sexo masculino que usufruem do benefício de saídas sistemáticas (saídas para passar os finais de semana em família). A UNISS tem atualmente capacidade para receber 80 adolescentes.

\section{A Unidade de Internação de São Sebastião - UISS.}

Em 2014, foi inaugurada a UISS (localizada no Núcleo Rural Aguilhada, na Região Administrativa de São Sebastião - DF). Essa unidade acrescentou mais 90 vagas para o atendimento a adolescentes do sexo masculino em cumprimento de internação provisória e internação estrita.

\section{A Unidade de Internação de Santa Maria - UISM.}

A UISM, também inaugurada em 2014, é a única unidade mista, ou seja, que atende meninos e meninas, no DF. Segundo o DODF de 15 de outubro de 2014, tem capacidade para atender até 90 adolescentes em cumprimento de internação provisória e de MSE de Internação.

Tabela 3. Unidades de Internação Provisória e de MSE de Internação no DF ${ }^{20}$

\begin{tabular}{|l|c|c|c|}
\hline Unidade de Internação & Ano de inauguração & Capacidade & Efetivo atual \\
\hline UIPSS & 2003 & 180 & 220 \\
\hline UNIRE & 2006 & 180 & 222 \\
\hline UIP & 2008 & 80 & 96 \\
\hline UNISS & 2014 & 80 & 58 \\
\hline
\end{tabular}

${ }^{20}$ Ressalta-se que o efetivo (número total de adolescentes) pode variar de um dia para outro. Portanto, esse total corresponde à data de 09 de fevereiro de 2015. 


\begin{tabular}{|l|c|c|c|}
\hline UISS & 2014 & 90 & 180 \\
\hline UISM & 2014 & 90 & 154 \\
\hline Total & - & 700 & 930 \\
\hline
\end{tabular}

É possível notar mudanças e transformações na execução da MSE de Internação e no acautelamento em internação provisória: a descentralização das unidades de internação - o que favorece a participação das famílias dos/das adolescentes no processo socioeducativo; o aprimoramento dos aspectos arquitetônicos dessas unidades; o acautelamento seguindo as determinações do ECA e da Lei do SINASE, entre outras.Todavia, cabe ressaltar, até então essas mudanças voltavam-se unicamente para o atendimento aos adolescentes do sexo masculino.

Na subseção seguinte voltamos o foco para o atendimento socioeducativo às adolescentes, no Distrito Federal.

\section{$O$ atendimento socioeducativo às adolescentes no Distrito Federal: trajetória e transformações.}

As novas unidades de internação inauguradas no DF não continham módulo feminino. Durante muitos anos a UIPP/CAJE, unidade de internação mais antiga do Distrito Federal e a que mais apresentava problemas e dificuldades que inviabilizavam o processo socioeducativo, foi a única a receber adolescentes do sexo feminino.

O Módulo Feminino do CAJE funcionou até meados de 2012. Com capacidade para atender até 12 adolescentes em cumprimento de internação provisória e MSE de Internação, em alguns períodos chegou a abrigar mais de 30. As adolescentes eram acauteladas sem separação por idade, compleição física ou gravidade do ato infracional. Essa característica do atendimento reitera algo comum entre muitas unidades de internação no Brasil: a superlotação e a consequente inadequação dos espaços 
destinados ao atendimento aos/às adolescentes em cumprimento de medidas socioeducativas.

Em agosto de 2012, como parte das medidas de desativação do CAJE/UIPP, as adolescentes foram transferidas para a Unidade de Internação do Recanto das Emas UNIRE (antigo CIAGO). Embora essa unidade apresentasse uma estrutura física mais moderna do que a unidade anterior, o espaço ainda não era suficiente para a (crescente) demanda, visto que o módulo feminino, por exemplo, que tinha capacidade para atender até 20 adolescentes, já chegou a atender 50 (L. Guercio, comunicação pessoal, agosto de 2014).

Desse modo, embora a SECRIA anunciasse, de acordo com matéria publicada no Jornal de Brasília de 24/08/2013, que essa transferência "simbolizava o esforço de se garantir que os princípios do ECA e da Lei do SINASE fossem respeitados", as condições de atendimento revelavam indicadores de que pouca coisa havia mudado. Isso se expressava na superlotação do módulo feminino, e nas consequentes dificuldades, dessa superlotação, no atendimento às adolescentes.

Cabe ressaltar que, embora essa transferência fosse uma medida anunciada como sendo de caráter provisório, já que uma das novas unidades de atendimento anunciadas pelo GDF em 2013 estaria voltada para o atendimento exclusivo do público feminino ${ }^{21}$, as adolescentes lá permaneceram por 21 meses.

Em fevereiro de 2014 o GDF inaugurou a Unidade Feminina de Semiliberdade do Guará, localizada na região administrativa de mesmo nome. Com espaço para receber 20 adolescentes, essa unidade busca atender plenamente à proposta arquitetônica estabelecida na resolução 119/2006 do CONANDA, que determina que as unidades de semiliberdade devem estar localizadas em bairros comunitários e instaladas

\footnotetext{
${ }^{21}$ Essa Unidade Feminina será custeada e gerida por meio de uma parceria entre o GDF e a Secretaria de Direitos Humanos da Presidência da República.
} 
em moradias residenciais. Quanto à rotina das adolescentes acauteladas, durante o dia elas são encaminhadas a escolas localizadas na própria comunidade. Para as atividades de esporte, cultura e lazer, os/as educadores/as buscam parcerias (públicas e/ou privadas) também junto a essa comunidade. Todas as atividades contam com o acompanhamento dos/das educadores/as sociais responsáveis pela execução da medida. Já para as atividades de profissionalização, a unidade ainda está em processo de organização para a inclusão das adolescentes no mercado de trabalho. (B. Nascimento, comunicação pessoal, agosto de 2014).

Todavia, embora essa MSE esteja prevista pelo Estatuto da Criança e do Adolescente desde a sua implementação, até então o Distrito Federal não dispunha de uma instituição com condições específicas e adequadas para atender às adolescentes. Como consequência, muitas acabavam sentenciadas à MSE de Internação apenas porque o estado não dispunha de condições de atendimento em semiliberdade.

Sobre as dificuldades decorrentes da inexistência do atendimento em semiliberdade até a inauguração dessa unidade, Judith, codinome de uma das adolescentes participantes da pesquisa, relata em 23/05/2014:

“O juiz me deu uma semi e me jogou na rua... Que semi foi essa? Eu nunca nem fui. Nem tinha semi pra mulher ainda. Onde eu ia me apresentar? [o juiz] Falou que ia me chamar pra audiência, mas nunca me chamou. Quando chamou, foi pra me mandar pra Internação.”

Atualmente a Unidade de Internação de Santa Maria (UISM) é a única no Distrito Federal a acautelar adolescentes do sexo feminino que estão em cumprimento de internação provisória e de MSE de Internação. Diferentemente das demais unidades pelas quais já passaram as adolescentes que cumprem medida de privação de liberdade no DF, a estrutura dessa unidade permite que as adolescentes sejam acauteladas de acordo com o que determinam o ECA e a Lei do SINASE (R. Ferreira, comunicação pessoal, setembro de 2014). Isso porque, por haver três módulos femininos distintos, é 
possível acomodá-las para o cumprimento da medida "obedecendo rigorosa separação por critérios de idade, compleição física e gravidade da infração" (ECA, 2002, p. 26, art. 123).

O parágrafo único desse mesmo artigo (art. 123) determina que "Durante o período de internação, inclusive provisória, serão obrigatórias atividades pedagógicas". Entretanto, embora fosse possível perceber o esforço das equipes técnicas para que as adolescentes estivessem envolvidas em atividades educativas, à época da pesquisa a unidade ainda estava em fase final de construção. Esse fato dificultava o planejamento da Jornada Pedagógica ${ }^{22}$ e a realização de atividades de profissionalização, esporte, cultura e lazer e fazia com que as adolescentes permanecessem ociosas, ficando grande parte do dia e da noite nos módulos ou nos quartos, conforme alguns relatos colhidos durante a pesquisa, que reproduziremos abaixo:

“A gente passa o tempo todo dentro do quarto. Sem TV, sem caneta, sem lápis, nem folha (Guacira, em 23/05/2014)”.

“A minha rotina é só dormir. Dormir e acordar, dormir e acordar. De vez em nunca aparece uma coisinha aqui, outra ali... (Judith, em 23/05/2014)”.

“Não temos escola há mais de mês, pra falar a verdade... (Naomi, em 23/05/014)”.

As medidas socioeducativas têm como objetivo principal a reinserção social e comunitária do/da adolescente. Para isso devem ser garantidas a sua proteção e o seu bem estar nas unidades de atendimento, bem como a sua participação em atividades educativas: escolarização, profissionalização e atividades culturais e de lazer. Entretanto, nota-se que apesar dos avanços na legislação, o atendimento socioeducativo,

\footnotetext{
${ }^{22}$ A Jornada pedagógica de uma Unidade de Internação pode ser definida como um roteiro, ou seja, como uma programação de todas as atividades a serem desenvolvidas pelos/as adolescentes ao longo de um determinado período (dia, semana ou mês). Cabe ressaltar que, por ser esse um contexto em que as estratégias que visam à segurança (tanto dos adolescentes quanto dos educadores e funcionários que atuam na instituição) devem ser cuidadosamente elaboradas, a estruturação e organização dessa Jornada envolve inúmeros aspectos a serem considerados (R. Ferreira, comunicação pessoal, setembro de 2014).
} 
muitas vezes, representa muito mais uma violação de direitos do que um meio para uma mudança de trajetória de vida (Ramos, 2010; Vieira, 2004; Yokoy de Souza, 2007). É possível notar que ainda persiste um imaginário social que desqualifica a adolescente que comete ato infracional, preconceito esse que se reflete no atendimento e toma corpo dentro das próprias unidades de internação (tema que emergiu nos resultados do presente estudo). Todavia, apesar de muito relevante, a ausência de políticas de atendimento socioeducativo específica para as adolescentes, bem como as desigualdades de gênero que se traduzem em desvantagens para elas, ainda compõem um tema pouco pesquisado no Distrito Federal.

Ao assumirmos a perspectiva de que o sujeito psicológico se constitui na interação com os outros e com o seu contexto físico, simbólico e sociocultural, enfatizamos a sua capacidade de promover transformação. Por ser ativo e não um simples receptáculo é participativo na construção de valores, costumes e modos de pensamento. Nesse sentido, concordamos com Vieira (2004) quando sugere que as instituições de atendimento socioeducativo se constituem num processo dialético, onde os valores e os costumes são construídos, interpretados e desconstruídos historicamente por aqueles que nelas vivem (os/as adolescentes) e trabalham (os/as educadores/as), e que sobre elas produzem significados.

Assim sendo, compreender as narrativas das adolescentes acerca do processo socioeducativo implica compreender, também, o contexto específico em que estão inseridas. Por esse motivo buscamos com essa pesquisa dar voz às adolescentes que se encontram em cumprimento de medida socioeducativa de internação. Por meio de suas narrativas e de interações estabelecidas com o outro procuramos analisar as significações construídas sobre o processo socioeducativo, reconhecendo a sua influência no desenvolvimento da subjetividade dessas adolescentes.

Após a apresentação do referencial teórico utilizado nesse estudo, no capítulo seguinte serão apresentados os objetivos de nossa pesquisa. 


\section{Capítulo III:}

\section{Objetivos}

O presente estudo está ancorado na perspectiva teórico-epistemológica da psicologia sociocultural, ao mesmo tempo em que busca oferecer contribuições para os estudos de gênero e para os estudos sobre socioeducação. Assim sendo, foi norteado pelos seguintes objetivos:

\section{Objetivo Geral:}

Investigar, em contexto de oficina pedagógica, como as adolescentes em cumprimento de medida socioeducativa de internação no Distrito Federal significam o processo socioeducativo.

\section{Objetivos Específicos:}

1. Analisar se e em que condições concretas o processo socioeducativo se converte em contexto mediador de transformação pessoal da adolescente;

2. Compreender como as práticas institucionais cotidianas promovem possibilidades ou criam barreiras para o desenvolvimento subjetivo das adolescentes;

3. Interpretar os processos de significação das adolescentes sobre sua inserção no contexto socioeducativo;

4. Propor uma metodologia construtiva, na forma de oficina pedagógica, que favoreça a reflexão e a discussão de questões relativas ao processo socioeducativo. 


\section{Capítulo IV:}

\section{METODOLOGIA}

\section{Considerações Teórico-Metodológicas}

No cenário contemporâneo das pesquisas em ciências humanas são possíveis novas formas de construção de conhecimento. Diferentemente da perspectiva positivista adotada pelas ciências modernas - em que prevaleciam a neutralidade do pesquisador, o instrumentalismo e o controle -, a epistemologia qualitativa tem seu foco voltado especificamente para os referenciais epistemológicos críticos. Nesse sentido, "A pesquisa qualitativa não se baseia em um conceito teórico e metodológico unificado" (Flick, 2004, p. 22), mas em compreender a produção de conhecimento enquanto um processo complexo, dinâmico, contínuo e não linear, sobretudo quando se trata de processos de desenvolvimento humano (Madureira \& Branco, 2001; Flick, 2004).

Nas palavras de Madureira \& Branco:

Um dos pressupostos centrais que diferenciam o positivismo de uma proposta epistemológica qualitativa diz respeito à compreensão da realidade em sua complexidade e não como algo que possa ser descrito a partir de poucas leis universais (2001, p.66).

Nos métodos qualitativos a comunicação do pesquisador com o campo e com os sujeitos da pesquisa é intrínseca à construção do conhecimento científico. Isso porque, sob essa perspectiva epistemológica, "As subjetividades do pesquisador $e$ daqueles que estão sendo estudados são parte do processo de pesquisa" (Flick, 2004, p. 22, grifo do autor). O conhecimento científico é, portanto, fruto de uma construção compartilhada entre pesquisador/a e sujeitos pesquisados. 
Desse modo, a investigação e a interpretação dos fenômenos que se desenvolvem em uma realidade complexa e na interação entre o sujeito e o seu contexto sócio-histórico-cultural pressupõem uma proposta epistemológica que considere fortemente o papel da cultura no desenvolvimento humano (Madureira \& Branco, 2001). Nesse cenário, a epistemologia qualitativa surge, portanto, como uma demanda por novos paradigmas, visto que permite ao pesquisador investigar o universo dos significados, das crenças e dos valores que se expressam e que são ressignificados em narrativas.

Os pressupostos da epistemologia qualitativa e da perspectiva sociocultural norteiam as reflexões e o planejamento metodológico desta pesquisa. A nossa aposta ético-política para esse estudo visou possibilitar, às adolescentes em contexto de internação, um espaço para a participação e a reflexão sobre as formas de inclusão e exclusão que vivenciam no cotidiano das relações sociais que estabelecem (ou não) na instituição socioeducativa. Nesse sentido, a epistemologia qualitativa possibilitou, a partir da análise das narrativas dessas adolescentes, a investigação dos significados atribuídos à Medida Socioeducativa de Internação.

Com base na metodologia da pesquisa-intervenção, adotamos a Oficina como principal procedimento de construção de informações da pesquisa. Essa metodologia, como abordagem qualitativa, circunscreve um campo que complementa outros modos de investigar consoante a construção sociocultural do que é investigado. Nas palavras de Castro \& Besset (2008):

A pesquisa-intervenção descortina um modo de fazer pesquisa fecundo na sua articulação entre o que se investiga e como se investiga. Em relação ao campo da infância e da juventude, isso quer dizer que a construção de pesquisas 
com crianças e jovens, e não sobre elas, determina de modo irretratável o modo da investigação (p.11, grifo da autora).

A escolha dessa orientação teórico-metodológica pressupõe, portanto, o estabelecimento de uma relação de confiança entre pesquisador/a e sujeitos pesquisados. O conhecimento científico construído ao longo da pesquisa decorre da relação dinâmica entre esses atores. O percurso metodológico é, portanto, uma produção relacionada à construção compartilhada do grupo envolvido na pesquisa. Nesse sentido, Menezes, Arcoverde \& Libardi (2008) acrescentam que "Pesquisador e participantes não são considerados como entidades distintas a priori, mas sim mergulhados num campo de permeabilidade, onde os objetivos da própria investigação são constantemente refeitos e transformados" (p.208).

Sob essa perspectiva teórico-metodológica, o intervir e o pesquisar são parte de um mesmo processo. As reflexões críticas acerca do fenômeno pesquisado sustentam as formas de intervir de modo a contribuir para a transformação social dos grupos com os quais atuamos (Prado, Oliveira \& Oliveira Junior, 2008). Desse modo, podemos afirmar que formular perguntas e convidar à reflexão são, também, formas de intervir (Sato, 2008). Assim, nessa modalidade de construção de conhecimento a ação do/a pesquisador/a está diretamente articulada a um campo de transformações que ele/a almeja alcançar junto aos sujeitos participantes.

Por fim, entendemos que nas instituições privativas de liberdade ainda são incomuns discussões acerca das significações das/dos adolescentes sobre as medidas socioeducativas, o que prejudica a possibilidade de que assumam uma perspectiva reflexiva sobre a MSE e sobre $\mathrm{o} / \mathrm{s}$ atos/s cometidos e o próprio processo de responsabilização (Rebouças, 2015). Para a realização desse estudo foi necessário, 
portanto, desenvolver estratégias de pesquisa que possibilitassem o acesso às adolescentes que se encontravam em um contexto tão diferenciado de outros contextos de desenvolvimento: uma instituição socioeducativa de internação. Isso porque, para compreender as experiências de vida dessas adolescentes, bem como as significações que atribuem à experiência socioeducativa, foi preciso antes de tudo situar o contexto onde essas experiências eram vivenciadas.

Nesse sentido, a Oficina nos pareceu ser o caminho metodológico mais apropriado e oportuno para a criação um espaço de interação e de (re)negociação de sentidos e significados entre as participantes da pesquisa (pesquisadoras e adolescentes).

\section{Método}

A pesquisa-intervenção pode ser compreendida como um método específico de abordar adolescentes para, com eles/as e para eles/as, construir conhecimento (Castro \& Besset, 2008). Nesse sentido, nosso estudo baseia-se desse método para construir, com adolescentes que estão cumprindo medida socioeducativa de internação, significações em torno do processo socioeducativo.

Assim, com o objetivo de criar um espaço voltado para a participação e a reflexão sobre o processo socioeducativo pelo qual passam essas adolescentes, chegamos ao que juntas denominamos de Oficina de Reflexão, proposta que será detalhadamente descrita neste capítulo. 


\section{Procedimentos e Cuidados Éticos.}

O projeto de pesquisa foi submetido à apreciação do Comitê de Ética em Pesquisa do Instituto de Ciências Humanas da Universidade de Brasília. Após a autorização desse Comitê e da apresentação dos objetivos da pesquisa para a Equipe de Direção das duas unidades de internação, foi possível iniciar a intervenção com as adolescentes.

Considerando que a pesquisa seria realizada com adolescentes em cumprimento de Medida Socioeducativa de Internação, e que, portanto, estariam sob a tutela do Estado, foram necessárias autorizações junto à Vara de Execução das Medidas Socioeducativas do DF - VEMSE (apêndice 01) e à Secretaria da Criança do Distrito Federal - SECRIA - secretaria responsável pela execução das medidas socioeducativas no DF (apêndice 02).

Além dessas autorizações, as adolescentes assinaram um Termo de Assentimento (apêndice 03), onde confirmaram que a sua participação na pesquisa aconteceria por livre escolha e sem qualquer influência em sua medida socioeducativa. Antes da assinatura do Termo de Assentimento, a pesquisadora apresentou o projeto às adolescentes, explicitando os objetivos da pesquisa e contextualizando a importância do tema e da participação de cada uma. É interessante ressaltar que os encontros não puderam ser gravados em vídeo, visto que somente a gravação em áudio foi autorizada pela juíza da VEMSE.

A subseção seguinte apresenta o contexto em que se deu esta pesquisa. 


\section{Contexto de Realização da Pesquisa.}

A presente pesquisa se deu no contexto do Sistema Socioeducativo do Distrito Federal. Todavia, em virtude do momento de reorganização e de reformulação do atendimento socioeducativo nas unidades de internação, ocorrido ao longo do ano de 2014, conforme detalhado na subseção: A MSE de Internação: histórico do atendimento no Distrito Federal,o processo de construção dos dados da pesquisa aconteceu em duas unidades de internação distintas: Unidade de Internação do Recanto das Emas - UNIRE e Unidade de Internação de Santa Maria - UISM, respectivamente.

A intervenção ocorreu ao longo de dez encontros, sendo que os quatro primeiros foram realizados em uma unidade de internação localizada na Região Administrativa do Recanto Das Emas, ao longo dos meses de outubro e novembro de 2013. Os demais encontros $(n=6)$ foram realizados em uma unidade de internação localizada na Região Administrativa de Santa Maria, ao longo do mês de maio de 2014.

Cabe destacar o fato de que a transferência do módulo feminino de uma unidade para outra trouxe incertezas quanto à possibilidade de continuação da intervenção. Isto posto, contar com a colaboração da equipe gestora da unidade que passara a acautelar as adolescentes foi fundamental para que o retorno da pesquisadora a campo se concretizasse.

Para facilitar a compreensão desse contexto específico, optamos pelo estilo literário da crônica para ilustrar o cotidiano das duas unidades de internação em que essa pesquisa foi realizada. É interessante ressaltar que nosso objetivo com essas crônicas é compartilhar com o leitor nossas percepções acerca da realidade institucional de cada uma das duas unidades. Sendo assim, na primeira crônica apresentamos o nosso olhar sobre o cotidiano da Unidade de Internação onde foram realizados os quatro 
primeiros encontros da Oficina de Reflexão. Na segunda, apresentamos nossas percepções acerca do cotidiano institucional da Unidade de Internação onde ocorreram os demais encontros $(n=6)$ da Oficina de Reflexão.

\section{Crônica 1 A Unidade de Internação "A"}

Depois de 40 minutos de estrada estacionei o carro, respirei fundo e, com a autorização da juíza da VEMSE em mão, me dirigi ao portão de entrada da instituição que acautelava as adolescentes que estavam em cumprimento de medida socioeducativa de internação no DF. O local, é verdade, já me era familiar, pois desde a sua inauguração, em 2006, até o ano de 2009, eu lecionara na escola que fica lá dentro.

Autorizada a minha entrada, segui pela calçada que me levaria à escola, impressionada (mais uma vez) com a beleza daquele lugar. O gramado, com o campo de futebol ao fundo, estava muito verde, dando a impressão de ser regado com frequência. As casas onde ficam os/as internos/as estavam todas muito bem pintadas - cada uma de uma cor diferente, em tons pastéis de amarelo, rosa, azul e verde - e, ao lado, estava a quadra de esportes que aparentava estar tão nova quanto na inauguração da Unidade. A escola (assim como tudo o que eu havia visto até ali) estava visivelmente em melhores condições do que à época em que eu trabalhara na unidade. Logo na entrada uma parede expunha as produções dos alunos realizadas nas aulas de artes. Ao longo do corredor, as salas de aula, bastante amplas, comportavam cinco fileiras de carteiras estilo universitário, uma mesa e cadeira para o professor e um enorme quadro branco (que nem de longe me lembrava o antigo quadro-negro empoeirado de giz). A biblioteca, muito bem equipada, tinha em torno de quatro ou cinco jogos de mesas com cadeiras e várias estantes de livros que, aparentemente bem organizados, poderiam atender aos 
mais diversos gostos e estilos literários. No final do corredor havia uma sala para os/as professores/as, duas salas utilizadas pela secretaria e pela Direção da escola e uma copa/cozinha equipada com geladeira, filtro, micro-ondas e uma cafeteira elétrica. No centro, uma mesa grande o suficiente para reunir os colegas na hora das refeições. Em frente às salas de aula havia um jardim com flores e pequenos pés de árvores frutíferas que eram parte de um projeto voluntário realizado pelo professor de Biologia. Ao lado desse jardim, uma mesa de pingue-pongue era utilizada pelos alunos durante os intervalos. Esse espaço recebia o nome de Bloco A da Escola.

Um pouco mais à frente, perto dessa mesa de pingue-pongue, ficava uma porta que dava acesso a outro espaço da escola, o Bloco B. Com exceção da biblioteca e das salas da Direção, a distribuição das salas era a mesma do Bloco A. Entretanto, o jardim em nada se parecia com aquele onde era realizado o projeto de Biologia. A grama, misturada ao mato, dava indícios de que há muito não era cortada. Não havia uma mesa de pingue-pongue, as paredes não estavam decoradas com os trabalhos dos alunos e na sala dos professores, apenas uma pequena mesa com poucas cadeiras. Na copa/cozinha, apenas um filtro de água e uma geladeira velha. Impactada pelas diferenças entre esses dois ambientes, perguntei à orientadora que estava me acompanhando se aquele espaço estava em desuso. Ela me respondeu: “Aqui estudam os adolescentes do M6, que é o módulo do seguro, e as adolescentes do módulo feminino.”. Emendei com outra pergunta: “Mas porque as meninas não estudam no Bloco A?". Sua resposta foi: “Porque elas dão muito trabalho, é melhor deixá-las aqui, longe dos meninos.”. Embora não tenha me contentado com a resposta, preferi encerrar o assunto.

Em seguida nos dirigimos à casa rosa, onde ficava o módulo feminino, que era chamado de Módulo 2 (M2). É interessante notar que nessa Unidade as casas/módulos que abrigam os/as adolescentes foram construídas todas seguindo um mesmo padrão: 
um quadrado dividido em quatro partes. Em cada uma dessas partes ficavam os quartos dos/as adolescentes internos/as e um pequeno pátio com bancos e mesas de concreto, um tanque de lavar roupas e uma área descoberta. Pelo meio dessas casas passavam dois corredores largos formando uma cruz. O corredor mais longo atravessava a casa de ponta a ponta, desembocando nas duas portas de acesso. No outro corredor ficavam, em cada uma das pontas, as salas de atendimento às adolescentes e às famílias. E bem no centro dessa cruz havia um espaço de convivência. Para cada um desses módulos havia uma equipe multidisciplinar de atendimento, composta por um/a pedagogo/a, um/a psicólogo/a e um/a assistente social. A segurança e o deslocamento das adolescentes dentro da Unidade eram realizados por equipes compostas por cinco ou seis Atendentes de Reintegração Social - ATRS. Essas equipes atuavam em escalas de plantão, divididas por módulos, e eram responsáveis também por fiscalizar se os/as internos/as estavam respeitando e cumprindo as normas da instituição. O módulo feminino - M2 aparentava ser limpo e bem organizado. As paredes, agora pintadas de rosa, contrastavam com o lilás das mesas e dos bancos. Algumas paredes também eram decoradas com pinturas de flores.

Assim que chegamos ao M2 fomos recebidas por uma Assistente Social (que era também a chefe da equipe desse módulo). Conversamos um pouco para que eu pudesse me apresentar e explicar a pesquisa que pretendia realizar com as adolescentes. Satisfeita com a minha proposta, ela se colocou à disposição para colaborar com o estudo. Enfatizou o quanto achava importante que trabalhos como esses fossem desenvolvidos também com as adolescentes, uma vez que normalmente apenas os adolescentes eram contemplados com atividades como essa. Depois de feitas as devidas apresentações, acertamos que as atividades com as adolescentes seriam iniciadas dali a uma semana. 
Passada aquela semana, voltei à Unidade para meu primeiro encontro com as adolescentes. Ao chegar ao M2 notei que a equipe de ATRS não era a mesma que estivera lá uma semana. Imediatamente me apresentei, explicando os motivos da minha visita. Imaginando que logo eu estaria com as adolescentes, fui surpreendida com uma série de indagações a respeito da atividade que eu realizaria com as adolescentes, como também sobre a autorização para a realização dessas atividades. Depois de mais ou menos uma hora e meia - entre muitas perguntas e uma longa espera - pude finalmente me reunir com as adolescentes.

Para todos os encontros foi necessária a mesma rotina. Eu chegava à Unidade $\mathrm{e}$ me apresentava para a equipe de plantão no módulo feminino. Respondia às mesmas perguntas e aguardava, pacientemente, o momento em que poderia iniciar as atividades com as adolescentes.

Enquanto esperava as adolescentes, eu aproveitava para observar um pouco do cotidiano dessa unidade. Assim, pude perceber indicadores de que aquele era um contexto rico em contradições. Enquanto outras unidades de internação tinham como um dos problemas a falta de espaço, naquela, ele sobrava. Em alguns momentos tive a impressão de que havia, na unidade, mais educadores (entre ATRS, professores e especialistas) do que adolescentes. A quadra de esportes poucas vezes vi sendo utilizada, apenas durante um jogo rápido de basquete ou outro. O refeitório estava em desuso, pois as refeições eram feitas dentro dos quartos. Dentre as oficinas profissionalizantes, apenas duas estavam em funcionamento - a de Panificação e a de Confecção de Bijuterias. Já as de Costura, Serigrafia, Cerâmica e Dança, fosse por falta de recursos materiais e/ou de profissionais - estavam fechadas. E, com tanto espaço verde, não havia nem mesmo uma pequena horta. Tantas possibilidades, mas tão pouco sendo feito... 
Refletindo sobre o que pude observar em relação à dinâmica da instituição, que aparentemente tinha espaço e condições favoráveis para que várias atividades pedagógicas fossem desenvolvidas com os/as adolescentes, tomei a liberdade de finalizar esta crônica parafraseando o cronista João Paulo Cuenca: "Tudo continuava dando um jeito diferente de continuar igual".

\section{Crônica 2- A Unidade de Internação “B”}

Alguns meses depois, quando poucas esperanças nos restavam para a realização de uma nova rodada de atividades com as adolescentes que complementariam a proposta da Oficina de Reflexão, finalmente conseguimos agendar uma visita à Unidade de Internação de Santa Maria - UISM.

Entretanto, para que o leitor possa melhor compreender as tantas e significativas mudanças pelas quais estava passando o SSE à época, e também o porquê da incerteza quanto à realização de outros encontros com as adolescentes, cabe aqui um pequeno relato de nossas impressões sobre o cenário político - especificamente para a Secretaria da Criança do DF - em que se deu a segunda parte da pesquisa. Analiso aquele momento como um período crítico, tenso e delicado. Isso porque em meio à transferência dos/as adolescentes para outras instituições, à redistribuição de cargos de chefia na SUBSIS - Subsecretaria do Sistema Socioeducativo - e à desativação da mais antiga Unidade de Internação do DF (onde estavam lotados, à época, pelo menos 700 profissionais da SECRIA), os servidores deflagraram uma greve que durou mais de 40 dias. Durante essa greve, as duas maiores categorias de funcionários que atuam no SSE do DF, os Atendentes de Reintegração Social - ATRS e os Especialistas, sem conseguir chegar a um acordo quanto às reivindicações trabalhistas, tomaram posições político- 
ideológicas divergentes e acirraram um conflito que há muito estava latente nas relações de trabalho. Assim, as unidades de atendimento socioeducativo passaram a funcionar com um número significativamente reduzido de profissionais.

A UISM - unidade em que seriam realizados os demais encontros da pesquisa havia sido inaugurada há apenas um mês e meio quando reiniciamos a pesquisa, em maio de 2014. Embora ainda estivesse em obras, logo após sua inauguração recebeu as adolescentes que ocupariam o módulo feminino. E, pouco a pouco, outros adolescentes chegavam transferidos de diferentes unidades de internação do DF. Os funcionários que tentavam "organizar a casa" eram aqueles que, ou ocupavam cargos de chefia, ou não tinham aderido à greve, ou que estavam trabalhando em escalas para cumprir o efetivo mínimo exigido por lei durante um movimento de paralisação.

Foi em meio a esse clima de incertezas que eu e minha auxiliar de pesquisa, chegamos à Unidade. Um tanto receosas, estávamos preparadas para uma recepção que, dadas as circunstâncias, poderia ser fria e desinteressada. Entretanto, para a nossa surpresa, fomos muito bem recebidas, e a equipe de direção se mostrou bastante interessada na pesquisa. Feitas as devidas apresentações, um ATRS de plantão nos levou para conhecer toda a Unidade.

Embora não houvesse espaço para gramados e jardins floridos - pois o lote, relativamente pequeno, era tomado por edificações por todos os lados - e fossem muitos os portões que atravessávamos à medida que íamos avançando para dentro da instituição, a "energia" que circulava naquele ambiente transmitia certa tranquilidade. Seguindo o que parecia ser um roteiro, a nossa primeira parada foi na escola. Distribuída em dois prédios, ela ainda estava sendo preparada para receber os/as alunos/as. As salas de aula, pequenas, comportavam poucos/as estudantes. Os 
corredores eram estreitos e dividiam em dois ambientes o espaço destinado a elas. A biblioteca ficava no prédio ao lado. Nela, os livros, a maioria recebidos por meio de doações, ainda estavam sendo catalogados e organizados nas poucas estantes que havia. Era visível que algumas salas ainda estavam em obras, pois havia materiais de construção e entulhos no chão. Descendo um pouco mais, havia um espaço onde ficavam os módulos femininos. Esse espaço era separado do restante da Unidade por um muro alto de concreto. Além dos módulos onde ficavam os dormitórios e pequenas áreas de lazer, havia também um prédio que, segundo a direção da unidade, seria futuramente utilizado para oficinas profissionalizantes exclusivamente femininas. Dividido em três ou quatro salas, esse prédio também não estava concluído. Ao fundo, ficava uma área descoberta, que serviria futuramente como uma quadra de esportes.

Chegando ao Módulo das sentenciadas, o M 7, a equipe de plantão nos recebeu muito bem. Conversamos sobre os objetivos da pesquisa e sobre as atividades (que passamos a chamar de "Oficina de Reflexão") que pretendíamos realizar com as adolescentes. Acertamos alguns detalhes necessários para o início da Oficina, como os dias, os horários e o local em que ela aconteceria. A fim de evitar contratempos relativos ao deslocamento das adolescentes, decidimos de comum acordo que as atividades da Oficina de Reflexão aconteceriam no espaço de convivência do próprio módulo.

Em seguida, algumas ATRS nos levaram para conhecer o restante do módulo, que era dividido em cinco ambientes. O primeiro, logo na entrada, era reservado para as ATRS, de onde elas podiam ver, através de um grande vidro, o que acontecia no módulo, especialmente no espaço de convivência. Nesse espaço de convivência havia três mesas retangulares dispostas em linha reta, com bancos dos dois lados e, um pouco à frente, um tanque para lavar roupas. Tanto as mesas quanto os bancos e o tanque eram 
de concreto, todos fixos no chão. Nas paredes não havia decoração alguma. Atrás dessas mesas, do lado esquerdo, ficavam uma área descoberta e um alojamento com oito quartos dispostos ao longo de um corredor. Cada quarto tinha apenas uma cama, embora acomodassem até três meninas ao mesmo tempo. Em outra ponta, do lado direito do módulo, havia outro alojamento com dois quartos, onde ficavam as adolescentes maiores de idade. Assim como no alojamento das "menores", naquele também faltava espaço suficiente para acomodar as adolescentes (que, ao completarem 18 anos, eram imediatamente transferidas para lá). A ATRS que estava nos acompanhando explicou que essa situação seria temporária, uma vez que outro módulo em fase final de construção, seria destinado às adolescentes maiores de idade.

$\mathrm{Na}$ data combinada, retornamos para o primeiro encontro da Oficina, realizado naquela Unidade. Embora a equipe de ATRS de plantão também dessa vez não estivesse a par da realização das atividades, rapidamente se organizou para que o encontro pudesse acontecer. E assim, sucessivamente, os encontros iam acontecendo.

É interessante ressaltar que embora essa etapa da pesquisa tenha sido realizada em um momento em que as adversidades no SSE estivessem "brotando como água", todos os encontros previstos para a segunda fase da Oficina de Reflexão se desenvolveram em um clima de paz e segurança tanto para as pesquisadoras como para as adolescentes e as equipes de plantão. Essa tranquilidade se refletia, sobretudo, nas atividades que desenvolvíamos e na interação entre nós, as adolescentes e as ATRS. Com isso era possível perceber que uma relação de confiança e respeito aos poucos estava sendo construída.

E agora, parafraseando Machado de Assis, que está entre os meus cronistas, contistas, romancistas e muitos outros 'istas' preferidos: "Há pessoas que choram por 
saber que as rosas têm espinhos. Há outras que sorriem por saber que os espinhos têm rosas".

Nós, certamente, escolhemos sorrir!

Após essa descrição, intencionalmente subjetiva, do contexto em que se realizou nossa pesquisa, o tópico seguinte será destinado à explanação, ao leitor, dos procedimentos de construção das informações da pesquisa, com ênfase na Oficina de Reflexão.

Procedimento de Construção das Informações da Pesquisa.

(a) A Oficina de Reflexão:

A Oficina de Reflexão constituiu o principal instrumento de pesquisa. Para a construção dos dados, no contexto da Oficina, foram utilizados diferentes recursos simbólicos como música, imagens, filmes e textos, sempre visando à reflexão sobre o atendimento e a MSE de Internação, o que será apresentado abaixo.

Todos os encontros da intervenção foram coordenados pela pesquisadora. Nos seis últimos encontros, além da pesquisadora houve a participação de uma estudante de graduação em Psicologia como auxiliar de pesquisa, que ficou encarregada de realizar os registros, monitorando os gravadores e realizando anotações na forma de diários de campo. As gravações em áudio foram depois integralmente transcritas pelas pesquisadoras. 
Tendo em vista o caráter dinâmico e processual da construção das informações da pesquisa, foram elaboradas atividades específicas para serem realizadas em grupo com as adolescentes. Desse modo, os encontros seguintes foram planejados de maneira que: (a) trouxessem informações suficientes para a reflexão e a discussão acerca das significações que compreendem o tema gênero (sexo, sexualidade, gênero, performance de gênero e construção social dos papeis de gênero); (b) favorecessem processos reflexivos sobre o gênero feminino no contexto da MSE de Internação; (c) constituíssem um contexto favorável à elaboração de autoimagens mais positivas pelas adolescentes; (d) permitissem levantar indicadores, a partir da perspectiva da pesquisadora e das adolescentes, de possíveis ações que atendessem às demandas das adolescentes quanto ao atendimento socioeducativo.

\section{(b) Os Cadernos de Reflexão:}

Outra importante fonte de dados consistia na produção de diários - chamados de "Cadernos de Reflexão". Esses cadernos permaneciam com as adolescentes que, conforme desejassem, podiam compartilhá-los com o grupo e/ou com a pesquisadora e a auxiliar de pesquisa. Nele eram registradas narrativas escritas que refletiam, sobretudo, as dificuldades e as dores vividas no cotidiano da instituição.

Um fator que acreditamos ter contribuído para a imersão das adolescentes no tema da pesquisa foi o interesse da professora de Arte - que lecionava na escola da UISM - pela temática de Gênero. Assim, aproveitando que esse seria um dos assuntos abordados ao longo dos encontros da Oficina de Reflexão, ela desenvolveu junto às adolescentes uma atividade denominada "Desconstruindo estereótipos de gênero através de máscaras". Para isso ela utilizou como pano de fundo assuntos relativos a corpo, gênero e sexualidade (apêndice 04). 


\section{Seleção das Participantes.}

As participantes foram selecionadas pela equipe de especialistas do Módulo Feminino, nas duas unidades de internação. A pesquisadora solicitou apenas que não participassem adolescentes que estivessem em internação provisória, visto que a proposta da Oficina era a de investigar os processos de reflexão e de ressignificação acerca da MSE de Internação.

A seguir apresentamos ao leitor duas tabelas. A primeira com informações básicas sobre as adolescentes participantes da Oficina de Reflexão. A segunda informa ao leitor quais adolescentes participaram de cada um dos dez encontros. Para finalizar a seção apresentamos uma breve caracterização de cada uma das participantes:

Tabela 4 - Informações básicas das participantes da Oficina de Reflexão

\begin{tabular}{|c|c|c|c|c|}
\hline $\begin{array}{c}\text { Pseudônimo e } \\
\text { Idade }\end{array}$ & $\begin{array}{l}\text { Tempo de } \\
\text { internação }\end{array}$ & $\begin{array}{c}\text { Cumprimento } \\
\text { Anterior de Medidas } \\
\text { Socioeducativas }\end{array}$ & Filhos/as & $\begin{array}{l}\text { Nível atual de } \\
\text { Escolaridade }\end{array}$ \\
\hline $\begin{array}{c}\text { Guacira - } 18 \\
\text { anos }\end{array}$ & $\begin{array}{c}\text { lano e } 05 \\
\text { meses }\end{array}$ & Não & Não & $\begin{array}{c}3^{\circ} \text { ano do Ensino } \\
\text { Médio }\end{array}$ \\
\hline $\begin{array}{l}\text { Maria da } \\
\text { Penha - } 17 \\
\text { anos }\end{array}$ & $\begin{array}{l}\text { 1ano e } 05 \\
\text { meses }\end{array}$ & Não & Não & $\begin{array}{c}2^{\circ} \text { ano do Ensino } \\
\text { Médio }\end{array}$ \\
\hline $\begin{array}{l}\text { Judith - } 20 \\
\text { anos }\end{array}$ & 11 meses & $\begin{array}{l}\text { Internação Provisória; } \\
\text { Liberdade Assistida; } \\
\text { Semiliberdade }\end{array}$ & Não & $\begin{array}{c}2^{\circ} \text { ano do Ensino } \\
\text { Médio }\end{array}$ \\
\hline $\begin{array}{c}\text { Chiquinha - } 16 \\
\text { anos }\end{array}$ & $\begin{array}{c}1 \text { ano e } 11 \\
\text { meses }\end{array}$ & Não & Não & $\begin{array}{l}7^{\circ} \text { ano do Ensino } \\
\text { Fundamental }\end{array}$ \\
\hline $\begin{array}{l}\text { Naomi - } 18 \\
\text { anos }\end{array}$ & 10 meses & $\begin{array}{l}\text { Internação Provisória; } \\
\text { Liberdade Assistida }\end{array}$ & $\begin{array}{l}1 \text { filha (2 } \\
\text { anos) }\end{array}$ & $\begin{array}{c}9^{\circ} \text { ano do Ensino } \\
\text { Fundamental }\end{array}$ \\
\hline $\begin{array}{l}\text { Sandra - } 15 \\
\text { anos }\end{array}$ & $\begin{array}{l}1 \text { ano e } 05 \\
\text { meses }\end{array}$ & $\begin{array}{l}\text { Internacão Provisória; } \\
\text { Liberdade Assistida }\end{array}$ & Não & $\begin{array}{l}9^{\circ} \text { ano do Ensino } \\
\text { Fundamental }\end{array}$ \\
\hline $\begin{array}{l}\text { Rose Marie - } \\
19 \text { anos }\end{array}$ & $\begin{array}{l}1 \text { ano e } 03 \\
\text { meses }\end{array}$ & Internação Provisória & $\begin{array}{l}1 \text { filho (2 } \\
\text { anos) }\end{array}$ & $\begin{array}{c}9^{\circ} \text { ano do Ensino } \\
\text { Fundamental }\end{array}$ \\
\hline $\begin{array}{l}\text { Maria Lacerda } \\
\quad-16 \text { anos }\end{array}$ & 05 meses & Não & $\begin{array}{l}1 \text { filha (3 } \\
\text { anos) }\end{array}$ & $\begin{array}{l}4^{\circ} \text { ano do Ensino } \\
\text { Fundamental }\end{array}$ \\
\hline $\begin{array}{l}\text { Nísia Floresta } \\
\text { - } 19 \text { anos }\end{array}$ & 11 meses & Não & $\begin{array}{l}1 \text { filho (2 } \\
\text { anos) }\end{array}$ & $\begin{array}{c}9^{\circ} \text { ano do Ensino } \\
\text { Fundamental }\end{array}$ \\
\hline
\end{tabular}




\begin{tabular}{|c|c|c|c|c|}
\hline $\begin{array}{c}\text { Bertha - 16 } \\
\text { anos }\end{array}$ & 06 meses & Não & $\begin{array}{c}\text { Estava } \\
\text { grávida de } \\
\text { sete meses }\end{array}$ & $\begin{array}{c}7^{\circ} \text { ano do Ensino } \\
\text { Fundamental }\end{array}$ \\
\hline $\begin{array}{c}\text { Simone - 17 } \\
\text { anos }\end{array}$ & 06 meses & $\begin{array}{c}\text { Internacão Provisória; } \\
\text { Liberdade Assistida e } \\
\text { Semiliberdade }\end{array}$ & Não & $\begin{array}{c}9^{\circ} \text { ano do Ensino } \\
\text { Fundamental }\end{array}$ \\
\hline
\end{tabular}

Tabela 5 - Participação nos encontros da Oficina de Reflexão

\begin{tabular}{|c|c|c|c|c|c|c|c|c|c|c|}
\hline Nome & $\begin{array}{c}1^{\mathbf{0}} \\
\text { encontro }\end{array}$ & $\begin{array}{c}2^{0} \\
\text { encontro }\end{array}$ & $\begin{array}{c}3^{\circ} \\
\text { encontro }\end{array}$ & $\begin{array}{c}4^{0} \\
\text { encontro }\end{array}$ & $\begin{array}{c}5^{\circ} \\
\text { encontro }\end{array}$ & $\begin{array}{c}6^{0} \\
\text { encontro }\end{array}$ & $\begin{array}{c}7^{0} \\
\text { encontro }\end{array}$ & $\begin{array}{c}8^{\circ} \\
\text { encontro }\end{array}$ & $\begin{array}{c}9^{\circ} \\
\text { encontro }\end{array}$ & $\begin{array}{c}10^{\circ} \\
\text { encontro }\end{array}$ \\
\hline Guacira & $\mathrm{X}$ & $\mathrm{X}$ & $\mathrm{X}$ & $\mathrm{X}$ & $\mathrm{X}$ & $\mathrm{X}$ & $\mathrm{X}$ & $\mathrm{X}$ & $\mathrm{X}$ & $\mathrm{X}$ \\
\hline $\begin{array}{c}\text { Maria } \\
\text { da } \\
\text { Penha }\end{array}$ & X & $X$ & $\mathrm{X}$ & $X$ & $X$ & $\mathrm{X}$ & $\mathrm{X}$ & X & $\mathrm{X}$ & $\mathrm{X}$ \\
\hline Judith & $\mathrm{X}$ & & $\mathrm{X}$ & & $\mathrm{X}$ & $\mathrm{X}$ & $\mathrm{X}$ & $\mathrm{X}$ & $\mathrm{X}$ & $\mathrm{X}$ \\
\hline $\begin{array}{c}\text { Chiquin } \\
\text { ha }\end{array}$ & $\mathrm{X}$ & $\mathrm{X}$ & $\mathrm{X}$ & $\mathrm{X}$ & $\mathrm{X}$ & $\mathrm{X}$ & $\mathrm{X}$ & $\mathrm{X}$ & $\mathrm{X}$ & $\mathrm{X}$ \\
\hline Naomi & $\mathrm{X}$ & $X$ & $\mathrm{X}$ & $X$ & $X$ & $X$ & & $\mathrm{X}$ & X & $X$ \\
\hline Sandra & $\mathrm{X}$ & $\mathrm{X}$ & $\mathrm{X}$ & $\mathrm{X}$ & & & & & & \\
\hline $\begin{array}{l}\text { Rose } \\
\text { Marie }\end{array}$ & $\mathrm{X}$ & $\mathrm{X}$ & & $\mathrm{X}$ & & & & & & \\
\hline $\begin{array}{c}\text { Maria } \\
\text { Lacerda }\end{array}$ & & & & & $X$ & $X$ & $X$ & $\mathrm{X}$ & $\mathrm{X}$ & $\mathrm{X}$ \\
\hline $\begin{array}{c}\text { Nísia } \\
\text { Florest } \\
a\end{array}$ & & & & & $X$ & $\mathrm{X}$ & $\mathrm{X}$ & & & $X$ \\
\hline Bertha & & & & & $X$ & $X$ & X & $\mathrm{X}$ & $\mathrm{X}$ & $\mathrm{X}$ \\
\hline Simone & & & & & $\mathrm{X}$ & $\mathrm{X}$ & $\mathrm{X}$ & $\mathrm{X}$ & $\mathrm{X}$ & $\mathrm{X}$ \\
\hline
\end{tabular}

\section{Caracterização das Participantes.}

Maria Lacerda ${ }^{23}$ tinha 16 anos e estava cumprindo medida socioeducativa pela primeira vez. Dentre as participantes era a que estava sentenciada há menos tempo (cinco meses). Estava no $4^{\circ}$ ano do Ensino Fundamental. Embora tenha participado apenas dos seis últimos encontros da Oficina de Reflexão, teve uma atuação bastante marcante durante as atividades, especialmente após compartilhar sua história de vida

\footnotetext{
${ }^{23} \mathrm{~A}$ escolha dos pseudônimos utilizados para essa pesquisa e deu por meio de uma atividade lúdica desenvolvida com as adolescentes durante o encontro n ${ }^{\circ} 10$ da Oficina de Reflexão. Essa atividade está detalhada na subseção descreve os encontros realizados ao longo da intervenção.
} 
com o grupo. "O pai da minha filha tá com 39 anos. Eu tava com ele desde que eu tinha 11 anos. Eu perdi a minha virgindade com ele, eu tinha 11 (anos). Aí com 12 eu engravidei, e com 13 eu tive ela (filha). Com 14 eu ainda tava com ele, com 15 também. Aí agora eu tenho 16. Ele terminou comigo. Nunca veio me visitar. E também não deixou eu visitar ele quando ele tava preso...” (Encontro $n^{0} 07$ da Oficina de Reflexão, em 19/05/2014).

Simone tinha 17 anos e já estava cumprindo MSE de Internação há seis meses, sendo essa a sua terceira internação. Também já havia cumprido Medida Socioeducativa de Liberdade Assistida. Embora fosse uma das mais caladas, estava sempre atenta às discussões do grupo. Utilizava bastante o Caderno de Reflexão para escrever sobre os seus dias na unidade de internação. "Hoje eu estou aqui, trancafiada, triste e arrependida, tentando encontrar um pouquinho de alegria, mas a solidão me abraça e me maltrata... mas eu sei que a minha liberdade um dia vai chegar..." (Trecho retirado do Caderno de Reflexão, em 2014).

Bertha era, aparentemente, a mais tímida de todas. Estava há seis meses cumprindo sua primeira medida socioeducativa. Cursava o $7^{\circ}$ ano do Ensino Fundamental. Tinha 16 anos e estava grávida de seis meses. "Meu namorado é o pai do meu bebê. Ele foi preso junto comigo. Agora ele tá na UNIRE." (Encontro n 07 da Oficina de Reflexão, em 19/05/2014).

Nísia Floresta tinha 19 anos e estava cumprindo sua primeira medida socioeducativa há onze meses. Esteve presente em apenas quatro encontros da Oficina de Reflexão pois havia sido selecionada, pela equipe técnica do módulo feminino, para trabalhar como auxiliar de escritório no Setor Médico da Unidade. Tinha um filho de dois anos, fruto de uma relação casual. "Eu acho que o pai do meu filho furou a camisinha. Ele queria 
formar uma família, ele gostava de mim e tudo... mas eu não amava ele... eu tava carente porque tinha terminado com o meu namorado..." (Encontro $\mathrm{n}^{\circ} 07$ da Oficina de Reflexão, em 19/05/2014).

Naomi era uma negra de voz grave e marcante. Tinha 18 anos e estava cumprindo MSE de Internação há dez meses, sendo que já havia cumprido outras medidas socioeducativas. Era mãe de uma menina de dois anos. Embora tivesse um companheiro/namorado, relacionava-se com outras meninas dentro da Unidade. Nos primeiros encontros da Oficina ela estava namorando a Chiquinha. Já nos últimos encontros ela namorava outra adolescente com quem dividia o quarto. "Eu ando muito estressada. Se envolver com mulher dá muito mais trabalho do que ficar com homem... eu me sinto sufocada... às vezes eu só quero ter um minuto pra pensar. Às vezes nem eu me entendo, sou cheia de dúvidas, uma pessoa indecisa." (Trecho retirado do Caderno de Reflexão, em 2014).

Chiquinha era, dentre as participantes, a que mais gostava de falar de si. Sempre que surgia uma oportunidade compartilhava suas vivências subjetivas com o grupo: "Sou arrependida por não ter me importado com os sentimentos dos outros. Mas me ensinaram a ser assim, a não pensar em ninguém. E muito menos em mim...”. (Trecho retirado do Caderno de Reflexão, em 2014). Tinha 16 anos e estava cumprindo medida de internação há um ano e onze meses. À época estava cursando o $7^{\circ}$ ano do Ensino Fundamental. Nos primeiros encontros da Oficina de Reflexão ela estava em um relacionamento com a Naomi. Da metade para o final estava namorando a Maria da Penha.

Maria da Penha era uma adolescente que ora utilizava o gênero feminino ora o masculino para falar de si: “Gente! Peraí que o parceiro aqui vai falar!” Tinha 17 anos 
e estava cursando o $2^{\circ}$ ano do Ensino Médio. Das adolescentes que participaram da Oficina de Reflexão, foi uma das mais atuantes. Gostava de ler os textos em voz alta. Expressava-se com facilidade e suas falas normalmente traziam reflexões sobre a Medida Socioeducativa. "Eu tinha vontade de escrever uma carta pro Ministério Público. Uma carta perguntando se eles realmente se importam com os jovens que estão aqui. Aqui não é só criminoso, são jovens que erraram, mas alguns querem mudar. Eles acham que só porque a gente é jovem e a pena é de três anos a gente quer continuar nessa vida?” (Encontro nº 08 da Oficina de Reflexão, em 23/05/2014).

Judith era uma moça de 20 anos. Estava em cumprimento de MSE de Internação há onze meses, sendo que já havia cumprido outras medidas socioeducativas. Cursava o $2^{\circ}$ ano do Ensino Médio. Participava das atividades, mas não gostava de falar de si. No primeiro encontro da Oficina de Reflexão afirmou, com convicção, que era heterossexual: “Eu só namoro homem!” (Encontro nº 03 da Oficina de Reflexão, em 12/11/2013). Da metade para o final da Oficina começou a namorar a Guacira. "Um momento marcante na minha vida foi quando conheci uma pessoa especial. Essa pessoa ficou marcada em mim pelo fato de ser presente, me dar carinho e me fazer feliz." (Trecho retirado de atividade realizada no encontro $\mathrm{n}^{\circ} 01$ da Oficina de Reflexão, em $31 / 10 / 2014)$

Guacira tinha 18 anos e estava cumprindo MSE de Internação há um ano e cinco meses. Essa era a sua primeira medida socioeducativa. Não tinha filhos e cursava o $3^{\circ}$ ano do Ensino Médio. Era delicada e falava pausadamente. Antes de namorar a Judith teve um relacionamento rápido com a Sandra. Participava das atividades sempre contribuindo com reflexões sobre a MSE. "Eu estou triste por ter perdido a minha liberdade, porém, estou vivendo um momento inédito e não premeditado, e isso me faz 
evoluir a cada dia..." (Trecho retirado de atividade realizada no encontro $\mathrm{n}^{\mathrm{o}} 01$ da Oficina de Reflexão, em 31/10/2014).

Sandra tinha 15 anos e estava cumprindo MSE de Internação há um ano e cinco meses. Estava no $9^{\circ}$ ano do Ensino Fundamental. Foi bastante participativa e gostava de compartilhar com o grupo o que escrevia em seu Caderno de Reflexão, sobretudo quando falava de sua paixão pela Guacira: "Você me faz sentir viva. Te amo como nuca achei que pudesse amar alguém." (Encontro $\mathrm{n}^{\mathrm{o}} 03$ da Oficina de Reflexão, em 12/11/2013). Sandra participou apenas dos quatro primeiros encontros da Oficina de reflexão, pois logo em seguida passou a cumprir MSE de Semiliberdade. Frequentemente era lembrada pelas colegas, que se referiam a ela sempre de forma carinhosa.

Rose Marie tinha 19 anos e era mãe de um menino de dois anos. Estava em cumprimento de medida de internação há um ano e três meses, sendo essa a sua primeira medida socioeducativa. Cursava o $9^{\circ}$ ano do Ensino Fundamental. Se dizia heterossexual e, durante a Oficina de Reflexão, revelou não se sentir à vontade quando as outras adolescentes falavam sobre suas relações homoafetivas: "Nem todo mundo gosta de ouvir sobre o namoro de vocês. Eu não gosto... me incomoda... tem que respeitar.” (Encontro n 03 da Oficina de Reflexão, em 12/11/2013).

\section{A Intervenção - Oficina de Reflexão.}

\section{Encontros e atividades.}

\section{Encontro $n^{\circ} 1$}


Local: Pátio de convivência do Módulo Feminino - M2 da Unidade de Internação do Recanto das Emas - UNIRE

Data: $31 / 10 / 2013$

Duração do Encontro: 1 h e 30 minutos

O primeiro encontro contou com a participação de sete adolescentes e da pesquisadora que coordenou as atividades. Com as adolescentes sentadas em círculo, a pesquisadora propôs uma rodada de apresentações. Em seguida a pesquisadora apresentou às participantes os objetivos da pesquisa e os cuidados éticos que estariam presentes ao longo de todo o processo de construção das informações. O registro em áudio, desses encontros, foi consenso entre todas.

Ainda nesse encontro foram brevemente discutidas as categorias sexo, sexualidade e gênero como uma forma de aproximação ao tema de pesquisa. Essa contextualização permitiu à pesquisadora perceber se esse era realmente um tema de interesse para as adolescentes.

Em seguida, a pesquisadora solicitou às adolescentes que realizassem uma atividade de registro escrito de uma vivência subjetiva marcante. Esse registro ajudou a pesquisadora na imersão do exercício da alteridade, cuja importância se refletia na compreensão e no acolhimento da perspectiva das adolescentes. Após a realização da atividade, as adolescentes decidiram, de comum acordo que essas narrativas seriam compartilhadas apenas com a pesquisadora.

Por fim, a pesquisadora sugeriu que as adolescentes realizassem um Diário ao longo dos encontros, enfatizando que este seria compartilhado somente de acordo com o interesse de cada uma delas. 


\section{Encontro $n^{\circ} 2$}

Local: Sala de aula do bloco B da Escola da Unidade de Internação do Recanto das Emas - UNIRE

Data: $06 / 11 / 2013$

\section{Duração do Encontro: 1 h}

O segundo encontro contou com a participação da pesquisadora/coordenadora e de seis meninas. O objetivo da atividade foi compreender a percepção das adolescentes acerca das regras e normas que regulam as condutas e as interações cotidianas do módulo feminino na instituição.

Para isso, a pesquisadora sugeriu que formassem uma roda de prosa. Como ponto de partida, a pesquisadora perguntou às adolescentes como era a rotina delas na Unidade. As adolescentes deram sequência ao diálogo falando sobre a rotina e os horários estabelecidos para as atividades pedagógicas e de lazer que realizavam ao longo da semana. As narrativas instigadas pela atividade e pelas intervenções da pesquisadora promoveram um rico debate sobre o atendimento às adolescentes durante o período de cumprimento da MSE de Internação.

A narrativa das adolescentes sobre o cotidiano dessa Unidade de Internação favoreceu a expressão da perspectiva das adolescentes sobre as diferenças de gênero que permeiam as atividades, os significados e os posicionamentos institucionais. Desse modo, as diferentes significações das adolescentes acerca da MSE de Internação emergiram como demanda principal para a construção compartilhada das atividades que seriam desenvolvidas ao longo dos demais encontros da Oficina de Reflexão. 


\section{Encontro $n^{\circ} 3$}

Local: Pátio de convivência do Módulo Feminino - M2 da Unidade de Internação do Recanto das Emas - UNIRE

Data: $12 / 11 / 2013$

Duração do Encontro: 1 h e 15 minutos

O terceiro encontro contou com a participação da pesquisadora e de seis adolescentes. O tema desse encontro teve como foco as diferentes expressões de afetividade nas relações interpessoais entre as adolescentes. É interessante notar que o assunto emergiu a partir do desejo, de uma das meninas, de compartilhar com o grupo o conteúdo de seu Caderno de Reflexão.

Esse encontro aconteceu no espaço de convivência do Módulo Feminino. Isso porque, embora estivesse previamente combinado que seria realizado em uma das salas de aula da escola, a Gerência de Segurança da Unidade alegou que, naquele dia, não havia ATRS em número suficiente para todos os deslocamentos previstos ${ }^{24}$.

\section{$\underline{\text { Encontro } n^{\circ} 4}$}

Local: Sala de aula do bloco A da escola da Unidade de Internação do Recanto das Emas - UNIRE

Data: $21 / 11 / 2013$

\footnotetext{
${ }^{24}$ Deslocamento é o termo utilizado nas unidades de internação para se referir ao ato de acompanhar os/as internos/as durante o trajeto para os locais em que são realizadas as atividades (ex: dos módulos para a escola; da escola para os módulos, etc.) Via de regra esse deslocamento é feito em fila, com as mãos para trás, a cabeça baixa e com os olhos voltados para o chão.
} 


\section{Duração do Encontro: $1 \mathrm{~h}$}

O quarto encontro da Oficina de Reflexão teve por objetivo suscitar os significados e sentidos do grupo acerca dos conflitos vividos no Módulo Feminino. Participaram a pesquisadora e sete adolescentes.

As reflexões construídas ao longo do encontro possibilitaram às adolescentes a ressignificação de crenças e valores que vinham, há algum tempo, gerando desentendimentos e dificultando a convivência entre elas.

Por fim, a pesquisadora explicou que, por conta do calendário de atividades planejadas para o Módulo Feminino, os demais encontros da Oficina de Reflexão aconteceriam somente após o início do ano letivo seguinte.

\section{$\underline{\text { Encontro } n^{\circ} 5}$}

Local: Pátio Interno do Módulo Feminino da Unidade de Internação de Santa Maria UISM

Data: $12 / 05 / 2014$

\section{Duração do Encontro: 1 h}

O quinto encontro da Oficina de Reflexão aconteceu cinco meses após o último encontro. Nessa data as adolescentes já haviam sido transferidas para uma nova unidade de internação. Participaram desse encontro a pesquisadora (que coordenou as atividades), uma auxiliar de pesquisa e nove adolescentes. Dessas nove meninas, cinco haviam participado dos primeiros quatro encontros. 
Esse encontro teve como objetivo a restituição do vínculo com a pesquisadora, a apresentação da auxiliar de pesquisa e a apresentação das adolescentes.

Inicialmente a pesquisadora apresentou os objetivos da pesquisa, bem como os cuidados éticos necessários para a construção das informações de pesquisa, às adolescentes que estavam participando pela primeira vez.

Em seguida, a pesquisadora e as adolescentes que participaram dos primeiros encontros fizeram uma breve contextualização das atividades desenvolvidas nos encontros anteriores. Após essa contextualização que funcionou como um aquecimento para o reinício dos encontros, foi entregue, para cada uma das meninas, uma pasta de papelão que serviria para a produção de um Portfólio. Esse Portfólio ficaria com as adolescentes. Nele seriam anexados os recursos utilizados ao longo da Oficina, como textos, figuras, letras de música, cartilhas, etc.

Foram também distribuídos novos Cadernos de Reflexão para cada uma das adolescentes. A pesquisadora fez questão de enfatizar que os registros do Caderno de reflexão seriam compartilhados somente se houvesse interesse da autora.

\section{Encontro $n^{\circ} 6$}

Local: Pátio Interno do Módulo Feminino da Unidade de Internação de Santa Maria UISM

Data: $16 / 05 / 2014$

Duração do Encontro: 1 h e 30 minutos 
O sexto encontro teve como objetivo a reflexão e discussão acerca do tema da construção social dos papéis de gênero, e das categorias sexo, sexualidade, gênero e heteronormatividade. A pesquisadora utilizou uma apresentação em Power Point como elemento disparador da discussão. Essa apresentação constava de pequenos textos, figuras e músicas, como também de narrativas biográficas de pessoas transgênero. As intervenções da pesquisadora possibilitaram a emergência de um rico material narrativo acerca das questões que nortearam a atividade.

Em seguida, a pesquisadora apresentou os videoclipes com letras das músicas (apêndice 5) “Tem pouca diferença”, interpretada por Gal Costa e Luiz Gonzaga (1984); “Masculino e Feminino”, interpretada por Pepeu Gomes (1983); “Lavagem Cerebral", interpretada por Gabriel O Pensador (1998). Inicialmente, as músicas foram ouvidas pelo grupo, que as acompanhou com a leitura das letras. Ao final das músicas, as adolescentes foram convidadas a expressar verbalmente o que sentiram e como significaram o conteúdo das músicas.

Por fim, a pesquisadora entregou para cada uma das adolescentes cópias das letras das músicas e de uma das figuras - Biscoito Sexual - utilizadas na apresentação (apêndice 6). Esse material foi anexado ao Portfólio.

Estiveram presentes nove adolescentes, a pesquisadora e uma auxiliar de pesquisa.

\section{Encontro $n^{\circ} 7$}

Local: Pátio Interno do Módulo Feminino da Unidade de Internação de Santa Maria UISM 
Data: $19 / 05 / 2014$

Duração do Encontro: 1 h e 10 minutos

Do sétimo encontro participaram a pesquisadora, uma auxiliar de pesquisa e oito adolescentes. A adolescente que não participou desse encontro estava finalizando a confecção de uma boneca de feltro na Oficina de Artesanato.

O objetivo desse encontro visou suscitar significados e sentidos do grupo acerca das concepções de gênero que perpassam suas interações sociais cotidianas - seja na comunidade, em família, com os amigos e/ou no contexto do atendimento socioeducativo.

Para isso a pesquisadora utilizou, como elemento disparador da discussão, dois curtas-metragens: a animação "Era uma vez outra Maria"; e "Acorda Raimundo, acorda!”. As narrativas suscitadas pela atividade e pelas intervenções da pesquisadora possibilitaram um rico debate sobre as significações das adolescentes acerca das concepções e dos posicionamentos de gênero que se expressam no mesocontexto (institucional) e no macrocontexto social.

\section{Encontro $n^{\circ} 8$}

Local: Pátio Interno do Módulo Feminino da Unidade de Internação de Santa Maria UISM

Data: 23/05/2014

Duração do Encontro: 1 h e 30 minutos 
O objetivo do oitavo encontro foi identificar, por meio das narrativas das adolescentes, os sentidos e significados que elas atribuem à MSE de Internação.

Para isso, a pesquisadora sugeriu que o grupo formasse uma roda de prosa. A partir das intervenções da pesquisadora as adolescentes deram sequência a narrativas acerca do atendimento socioeducativo.

Em seguida a pesquisadora sugeriu ao grupo uma atividade lúdica que consistia na construção de um mural - o qual foi denominado pelas adolescentes de "Mural dos Desejos” (apêndice 7). Para a confecção desse mural a pesquisadora entregou para cada adolescente uma flor recortada em cartolina. Cada flor era composta de cinco pétalas e um miolo. No miolo, cada adolescente escreveu o seu nome, e em cada um das pétalas, ações que, na sua opinião, poderiam contribuir para que o cumprimento da medida de internação fosse menos "penoso", e o atendimento socioeducativo, mais pedagógico. Depois que todas do grupo terminaram a tarefa, foram solicitadas pela pesquisadora a lerem em voz alta o que haviam escrito em suas flores

As ações sugeridas pelas adolescentes visavam, sobretudo, uma maior participação da família na experiência socioeducativa. Atividades pedagógicas e profissionalizantes também foram sugeridas por todas as adolescentes.

Nesse encontro estavam presentes a pesquisadora, uma auxiliar de pesquisa e oito adolescentes.

\section{$\underline{\text { Encontro } n^{\circ} 9}$}

Local: Pátio Interno do Módulo Feminino da Unidade de Internação de Santa Maria UISM 
Data: $26 / 05 / 2014$

Duração do Encontro: 1 h e 30 minutos

O nono encontro teve como objetivo suscitar um debate crítico sobre o tema da violência contra a mulher, com base na Lei 11.340/2006, conhecida como Lei Maria da Penha.

A pesquisadora utilizou dois vídeos como elementos disparadores de reflexão. Foram eles: “A Lei Maria da Penha em Cordel” e "A breve história de Maria da Penha: uma mulher lutadora”. Foram também utilizados textos e reportagens de revistas e jornais sobre o tema. As intervenções da pesquisadora possibilitaram a narrativa de experiências de violência de gênero vividas pelas adolescentes.

A pesquisadora então entregou para cada uma das meninas um rico material sobre o tema da violência de gênero. Esse material, que foi anexado ao Portfólio, consistia em cartilhas adquiridas na Secretaria de Políticas para as Mulheres da Presidência da República (Lei Maria da Penha; dados estatísticos sobre a violência de gênero no Brasil; programas do Governo Federal de combate à violência contra a mulher).

Em seguida a pesquisadora apresentou ao grupo o videoclipe da música "Rosas", de autoria do grupo de RAP feminino Atitude Feminina (apêndice 8). A música foi ouvida pelo grupo, que acompanhou cantando a letra (as adolescentes já conheciam a música e sabiam a letra praticamente de cor). Ao final da música a pesquisadora solicitou às adolescentes que verbalizassem para o grupo o que sentiram, pensaram e lembraram diante do conteúdo da música. 
Esse encontro contou com a participação da pesquisadora, de uma auxiliar de pesquisa e das oito adolescentes que estavam no encontro anterior. Cabe destaque ao fato de que duas adolescentes internas que não haviam participado dos encontros anteriores pediram para acompanhar as atividades da Oficina de Reflexão nesse dia. A pesquisadora, com a anuência da equipe de segurança de plantão e das demais participantes, autorizou a participação dessas duas meninas.

\section{Encontro $n^{\circ} 10$}

Local: Pátio Interno do Módulo Feminino da Unidade de Internação de Santa Maria UISM

Data: $30 / 05 / 2014$

Duração do Encontro: 1 h e 30 minutos

O décimo e último encontro contou com a participação da pesquisadora, de uma auxiliar de pesquisa e de nove adolescentes.

Esse encontro teve como objetivos: (a) a definição de um pseudônimo para cada uma das meninas; (b) a avaliação da Oficina de Reflexão.

Para o primeiro objetivo a pesquisadora sugeriu uma atividade lúdica chamada "Dinâmica dos Balões". Para isso foi entregue, aleatoriamente, um balão vazio para cada uma das meninas. Dentro de cada balão havia o nome de uma personagem dos movimentos feministas, seguido de um breve histórico de sua atuação em prol das mulheres e desses movimentos. As meninas encheram seus balões e, iniciada a música, brincaram de jogar os balões para o alto, de modo que todos se misturassem no ar. 
Quando a música acabou, cada uma deveria ter um balão em mãos. Em seguida, uma de cada vez, estourou o seu balão e leu para o grupo o seu pseudônimo, bem como a pequena biografia que acompanhava esse nome (apêndice 9).

Após essa atividade, a pesquisadora sugeriu um momento para a avaliação da Oficina de Reflexão. Foi dada a oportunidade para que todas as adolescentes falassem abertamente sobre seus sentimentos e impressões acerca dos encontros e das atividades realizadas ao longo da intervenção. As adolescentes falaram, sobretudo, da importância e necessidade de espaços de fala e de construção de conhecimento durante o período de cumprimento da MSE de Internação.

Em seguida a pesquisadora sugeriu que uma das adolescentes lesse em voz alta para o grupo o texto "As mentiras que contam sobre nós”, de Aline Valek (apêndice 10). Esse texto foi sugerido pela pesquisadora.

Por fim, a pesquisadora e a auxiliar de pesquisa ofereceram um lanche de confraternização para o grupo. Nesse momento a equipe de ATRS que estava de plantão no Módulo Feminino se juntou ao grupo para a confraternização.

Na subseção seguinte, apresentaremos ao leitor os procedimentos utilizados para a análise das informações da pesquisa, bem como para a construção dos episódios de análise.

\section{Procedimento de Análise das Informações Construídas nos Encontros das}

\section{Oficinas.}

A pesquisadora iniciou o processo de análise das atividades com a transcrição integral das narrativas orais construídas ao longo dos encontros da Oficina de Reflexão. 
O material resultante dessas transcrições foi lido e relido inúmeras vezes. As gravações dos encontros também foram ouvidas repetidas vezes para uma melhor compreensão dos processos metacomunicativos (entonação de voz, suspiros, risos, pausas, etc). Feito isso, foi possível identificar os principais eixos norteadores da produção de significados e temas recorrentes nas falas das adolescentes.

Em seguida, a pesquisadora realizou a pré-análise das narrativas das adolescentes, especificamente no que se refere às concepções de desenvolvimento humano, adolescência e cultura, à luz da perspectiva psicológica sociocultural. Essa etapa consistiu na identificação de indicadores empíricos a partir da leitura do material transcrito e da leitura dos Cadernos de Reflexão produzidos pelas adolescentes. Tendo em conta que, para a perspectiva cultural semiótica, que norteia o trabalho, os significados são dinâmicos e se definem necessariamente em relação dialógica com outros significados, esses indicadores foram organizados em quatro dimensões de análise, à luz das quais as narrativas das adolescentes foram analisadas. Tais dimensões de análise foram definidas em forma de termos pareados, em perene relação. Elas englobam temas, narrativas e interações vivenciadas pelas adolescentes, com ou sem a participação direta das pesquisadoras, durante as sessões da Oficina de Reflexão. Cada par destaca processos interdependentes ou em oposição, que ocorrem contra o pano de fundo dos sistemas de significados relacionados aos contextos interpessoal, institucional ou social da condição de internação para cumprimento de medida socioeducativa, a saber: 
Tabela 6 - Dimensões de análise

\begin{tabular}{|c|l|}
\hline Dimensão & \multicolumn{1}{|c|}{ Temas } \\
\hline 1 & Promoção de Desenvolvimento $\leftrightarrow$ Privação de Liberdade \\
\hline 2 & $\begin{array}{l}\text { O Olhar das Adolescentes Sobre a Instituição Socioeducativa } \leftrightarrow \text { O Olhar } \\
\text { Institucional Sobre a Infração Juvenil Feminina }\end{array}$ \\
\hline 3 & Interação Social $\leftrightarrow$ Isolamento \\
\hline 4 & Processos Reflexivos $\leftrightarrow$ Reprodução do Discurso Institucional \\
\hline
\end{tabular}

Em relação à dimensão denominada Promoção de Desenvolvimento $\leftrightarrow$ Privação de Liberdade incluem-se as produções de significados que tratam das contradições inerentes à natureza da MSE de internação, que ao privar a liberdade, reduz a autonomia e, com isso, as possibilidades de transformação pessoal da adolescente ao longo do cumprimento de medida, descumprindo a prerrogativa do ECA. Assim, busca-se analisar, nas narrativas de pesquisa, se e em quais situações concretas o processo socioeducativo se converte em contexto mediador de transformação pessoal da adolescente. Para isso considera-se o impacto da privação de liberdade nessa fase da vida, bem como da inserção e da permanência da adolescente nesse contexto diferenciado de normas, valores, linguagens e rotinas institucionais, quando comparado com as formas pregressas e futuras de socialização. Em termos dos processos de desenvolvimento, trata-se da tensão entre confinamento espacial e transformação temporal.

Na dimensão 2, denominada O Olhar das Adolescentes Sobre a Instituição Socioeducativa $\leftrightarrow$ O Olhar Institucional Sobre a Infração Juvenil Feminina, o que 
está em jogo são aqueles significados produzidos sobre a infração juvenil feminina, e em que medida as adolescentes recriam ou reproduzem em suas narrativas as ideologias dominantes no sistema, especificamente aquelas que retratam as desigualdades pautadas em questões de gênero. Em outras palavras, trata-se da percepção da adolescente: (i) quando inserida em um contexto majoritariamente masculino; (ii) em relação ao olhar institucional sobre a adolescente autora de ato infracional. Esta dimensão é a que revela mais fortemente as questões de gênero, trazendo à luz as desigualdades entre adolescentes do sexo feminino e adolescentes do sexo masculino no sistema socioeducativo.

No que tange à Dimensão 3, Interação Social $\leftrightarrow$ Isolamento, o alvo dessa dimensão são as oportunidades de interação entre as adolescentes acauteladas que são preservadas frente ao isolamento que caracteriza a privação de liberdade. Visa-se compreender o modo como as condições concretas de funcionamento institucional permitem e/ou promovem possibilidades (ou criam barreiras) para o desenvolvimento, as quais se manifestam na ressignificação dos valores e das crenças da adolescente sobre o impacto subjetivo do processo socioeducativo. Em termos de desenvolvimento humano, explora-se aqui o papel do outro no desenvolvimento pessoal.

\section{Por fim, a Dimensão 4 Processos Reflexivos $\leftrightarrow$ Reprodução do Discurso}

Institucional considera as falas indicadoras da emergência de perspectivas subjetivas críticas, em oposição à repetição dos próprios posicionamentos anteriores ao cumprimento de medida, assim como dos posicionamentos sociais dominantes. A Oficina de Reflexão, no caso, é tomada como um microcontexto mediador dos processos reflexivos e possibilitador da atividade narrativa criadora, por parte das adolescentes. Compreendemos, portanto, que a narrativa favorece novas tomadas de posição das interlocutoras e indica a construção de novos sentidos e significados. 
Tratando-se de desenvolvimento humano, essa dimensão se refere à possibilidade de as adolescentes alcançarem formas qualitativamente destacadas de consciência, ainda que em condição de desenvolvimento restritiva da criatividade.

\section{Construção dos Episódios de Análise.}

Os episódios de análise são trechos selecionados da Oficina de Reflexão, que representam momentos de interação e produção de narrativas significativas por parte das adolescentes participantes A seleção de episódios levou em conta a necessidade de ilustrar/fundamentar as quatro dimensões de análise acima descritas. Quando oportuno, outros breves trechos dos encontros (que não chegam a constituir episódios) foram inseridos na Análise/Discussão visando trazer mais elementos de sustentação para a argumentação e as interpretações realizadas.

Desse modo, foi possível uma análise qualitativa acerca das construções dialógicas de significados que permearam as interações e as narrativas partilhadas pelas adolescentes e pela pesquisadora, possibilitadas pela experiência da Oficina de Reflexão.

Nesse sentido, para as três primeiras Dimensões de análise foram selecionados trechos de narrativas que bem ilustrassem o tema da discussão. Essas narrativas serão apresentadas ao leitor por meio de epígrafes, que iniciam cada dimensão de análise, e também por meio de outros trechos das narrativas das adolescentes que, por oportunos e esclarecedores das interpretações anunciadas, foram incluídos na análise e discussão dos resultados. 
Para a quarta dimensão de análise foi adotada uma estratégia distinta. No caso, foi selecionado um episódio interativo do processo de construção das informações de pesquisa. Nele identificamos uma rica sequência de interações dialógicas, sendo assim considerado um evento singular relevante, indicador de reflexão e de tomada de consciência pelas adolescentes envolvidas. As sequências interativas foram identificadas por turnos $(\mathrm{T} 1, \mathrm{~T} 2, \mathrm{~T} 3, \ldots, \mathrm{Tx})$, para melhor visualização do caráter dialógico das enunciações.

Dessa forma, a seleção dos trechos e/ou episódio de análise foi baseada no entendimento da pesquisadora de que esses seriam expressivos para indicar processos de reflexão e de ressignificação de si e do contexto institucional. Cabe ressaltar que nossa proposta é de uma análise puramente qualitativa, tal como requer a epistemologia adotada.

Feita a apresentação da fundamentação teórico-metodológica utilizada nesse estudo, no próximo capítulo serão apresentados e discutidos os resultados da pesquisa. 


\section{Capítulo V:}

\section{Resultados e Discussão}

Conforme descrito no capítulo de Metodologia, o processo de abordagem das informações construídas nos encontros da Oficina de Reflexão foi norteado por quatro dimensões de análise. Os trechos analisados foram retirados de narrativas que ocorreram ao longo de toda a intervenção. Assim, ao final de cada trecho analisado aparecem o nome da adolescente e o tempo de internação, sendo que esse tempo varia em função do momento em que foram construídas as informações. As narrativas das adolescentes foram transcritas de maneira que a representação escrita se desse do modo mais próximo de seu proferimento original, respeitando-se o estilo e os demais aspectos pragmáticos da comunicação oral.

\section{Dimensão 1 - Promoção de Desenvolvimento $\leftrightarrow$ Privação de Liberdade.}

“Eu acho que a medida surte efeito nos três primeiros meses, que a gente começa a sentir saudade, começa a pensar coisas que realmente têm valor, mas depois... ninguém pensa em mais nada..." (Guacira, 18 anos, 1 ano e 05 meses de internação, em 23/05/2014).

"Eu acho, primeiramente, que a gente nem devia ficar preso... eu acho que a gente... a pessoa ficar presa um ano, dois ano, dez, 20 ano, não vai mudar nada... você acha que uma pessoa vai ficar 20 ano 'vegetando'? Vai pensar o que da vida dela? Vai mudar? Não, não vai mudar nada. Eu, só de falar, já fico indignada...” (Naomi, 18 anos, 10 meses de internação, em 23/05/2014).

As epígrafes selecionadas ilustram algumas das reflexões das adolescentes sobre a privação de liberdade. De acordo com elas, a MSE de internação ao invés de suscitar 
processos reflexivos e de ressignificação acerca do ato infracional cometido, funciona como uma mera punição do/a adolescente, frente às escolhas "erradas" que condicionaram a infração. Consoante a Resolução 119/2006 do CONANDA, a medida socioeducativa de internação não pode privar o/a adolescente de nenhum outro direito além da sua liberdade. Desse modo, ao longo do cumprimento da medida, devem ser asseguradas a realização de atividades de profissionalização, escolarização, esporte, cultura e lazer, como também o acesso à informação e à saúde. Ademais, dentre as Diretrizes Pedagógicas que devem fundamentar e orientar o atendimento socioeducativo ao/à adolescente em cumprimento de MSE, estão: (a) a prevalência da ação socioeducativa sobre os aspectos meramente sancionatórios e (b) a organização espacial e funcional das unidades de atendimento, de forma a garantir possibilidades de desenvolvimento pessoal e social para o/a adolescente.

Na primeira epígrafe, Guacira fala sobre os três primeiros meses de internação. Para ela, é nesse primeiro momento que a saudade (de casa, dos amigos e da liberdade) parece suscitar alguma reflexão sobre o ato infracional e suas consequências. Entretanto, essa fala é indicadora de que, embora exista um processo reflexivo sobre a medida socioeducativa, esta ainda é significada como uma estratégia de punição: a medida surte efeito porque desperta saudade. Mas, na medida em que ela se habitua àdor da saudade, passa a não pensar em mais nada, ou seja, o "efeito" (punitivo) da medida desaparece, dando lugar à ociosidade, ao "pensar em nada": “[...] mas depois... ninguém pensa em mais nada...”. Convergente com a perspectiva de Guacira, a narrativa de Naomi, na segunda epígrafe, aprofunda ainda mais a reflexão sobre as medidas de privação de liberdade. Ela utiliza, no início de sua fala, a primeira pessoa do singular (eu acho) indicando claramente a intenção de expressar a sua opinião acerca 
das medidas/penas ${ }^{25}$ privativas de liberdade. Ela dá sequência à sua narrativa revelando um jogo de posicionamentos em que ora ela é parte do grupo representado em sua fala (a gente), ora ela se refere a um "outro indeterminado" (a pessoa), que compartilha da mesma situação de exclusão social, de privação de liberdade e de dificuldades concretas de desenvolvimento: a pessoa ficar presa um ano, dois ano, dez, 20 ano, não vai mudar nada... você acha que uma pessoa vai ficar 20 ano 'vegetando'? Vai pensar o que da vida dela?". Assim como Guacira, para quem depois de três meses em cumprimento de medida de internação "ninguém pensa em mais nada", Naomi compara as medidas privativas de liberdade a um estado vegetativo, ou seja, uma condição de morte em vida, em que, se não ocorrem sequer sensações, percepções e sentimentos, o que se dirá de processos reflexivos!

A fala de Naomi é metaforicamente rica, especialmente quando se refere à medida/pena de privação de liberdade como um "estado vegetativo". Entretanto, ela traz à tona questões extremamente relevantes no que se refere aos processos de desenvolvimento humano em contexto de isolamento social e/ou privação de liberdade.

De acordo com a perspectiva sociocultural de desenvolvimento humano, não há como conceber desenvolvimento que não por meio das interações sociais (Madureira \& Branco, 2001, 2012, 2014; Vigotski, 2000, 2010, 2011; Valsiner, 1994, 2012). Isso porque, sob essa ótica, o sujeito se constitui subjetivamente por meio de sua relação bidirecional com o contexto no qual se desenvolve (Valsiner, 2012). Nesse sentido, considerando o papel do contexto sócio-histórico-cultural nos processos de desenvolvimento e de mudanças subjetivas, os/ as adolescentes que passam pela experiência da privação de liberdade apresentam uma configuração semiótica particular,

\footnotetext{
${ }^{25}$ Utilizamos os termos medidas e penas por entender que a narrativa de Naomi faz referência tanto às medidas socioeducativas como às penas privativas de liberdade, uma vez que ela fala em 2, 10 ou 20 anos.
} 
diferenciando-se daqueles/as que não compartilham a mesma experiência ao longo da sua trajetória de vida (Vieira \& Lopes de Oliveira, 2013; Yokoy de Souza, 2007). Nessa configuração - não menos complexa, mas diferente da dos que se desenvolvem em liberdade - o preconceito, a discriminação e a exclusão social fazem parte do cotidiano das adolescentes que cometem atos infracionais. A narrativa de Maria da Penha exemplifica bem essa situação:

"Você acha que só porque a gente é jovem e a pena é de três anos a gente quer continuar nessa vida? Lógico que não! Tem gente aqui que realmente quer uma vida diferente, mas não tem oportunidade... não há outra saída, a não ser isso aqui. Aqueles caras que ficam xingando a gente na TV, é porque não conhecem a nossa realidade.” (Maria da Penha, 17 anos, 1 ano e 5 meses de internação).

Maria da Penha inicia a sua fala questionando a crença disseminada pelo senso comum de que os/as adolescentes cometem atos infracionais motivados/as pela convicção de que "a pena é de três anos", portanto, branda, se comparada às penas aplicadas aos/às infratores/as maiores de idade. Ela direciona a sua pergunta à pesquisadora (você) que, nesse momento, representa o "outro" em relação às adolescentes infratoras: "Você acha que [...]”. Na sequência narrativa é possível perceber um jogo de posições, em que ora ela se refere de forma generalizada às adolescentes $($ a gente $=$ nós), ora restringe a representatividade de sua fala a um grupo (indeterminado) de adolescentes que desejam romper com a trajetória infracional: " $\underline{\mathrm{Tem}}$ gente aqui que realmente quer uma vida diferente, [...].”. A resposta de Maria da Penha à própria pergunta: "Lógico que não!" é um indicador de seu posicionamento de pertencimento ao grupo das adolescentes que anseiam por novas trajetórias de vida. A adolescente conclui sua fala trazendo à tona outra questão que parece ser igualmente incômoda para ela: o preconceito e a discriminação disseminados pelos meios de comunicação. 
De acordo com Madureira \& Branco (2012), existem, nos diversos contextos socioculturais, fronteiras simbólicas que delimitam de forma semipermeável as diferenças entre os sujeitos e os contextos sociais. Todavia, quando essas fronteiras se tornam rígidas, caracterizando alguns grupos a partir da desqualificação em relação a outros, é possível perceber o preconceito em ação, ou seja, a discriminação. Nesse sentido, o preconceito é um fenômeno social e psicológico que está relacionado à afetividade, enquanto a discriminação e/ou as práticas discriminatórias refletem o preconceito posto em prática. Desse modo, “[...] os preconceitos constituem-se historicamente em fronteiras simbólicas rígidas, com profundas raízes afetivas, funcionando como barreiras culturais entre pessoas e grupos sociais" (Madureira \& Branco, 2012, p. 131).

Sob essa perspectiva, podemos afirmar que a narrativa de Maria da Penha é rica em marcadores semióticos que revelam o seu incômodo diante da livre disseminação do preconceito em relação à infração juvenil. Entretanto, é na última frase do trecho citado que ela explicitamente mostra o seu descontentamento diante dessa generalização: "Aqueles caras que ficam xingando a gente na TV, é porque não conhecem a nossa realidade.” Ao se referir “àqueles caras”, Maria da Penha insere em sua argumentação uma alteridade importante para a conformação das concepções sociais sobre adolescência e violência. Isso porque ela tece uma crítica clara aos programas de jornalismo popular que, disseminando discursos conservadores sobre o adolescente e a maioridade penal, contribuem para a construção de uma visão estereotipada, generalizada e preconceituosa do/da adolescente que comete ato infracional. Assim, ela conclui a sua fala com uma afirmação que suscita novas perspectivas reflexivas: "é porque não conhecem a nossa realidade.". Nesse sentido, a narrativa de Maria da Penha traz à tona outra questão que, embora não seja o nosso foco principal de 
discussão nesse estudo, é igualmente relevante e atual: a criminalização da adolescência. No imaginário social parece haver uma constante associação entre o/a adolescente (especialmente o/a adolescente pobre) e o crescimento da violência, visto que a mídia, com sua redundância cotidiana, fomenta a imagem do/da adolescente que comete ato infracional como criminoso/a extremamente perigoso/a e desumano/a.

De acordo com Yokoy de Souza (2012), o estereótipo antissocial sobre os/as adolescentes que cometem atos infracionais tem sido legitimado pelo senso comum, pela mídia, pelos/as próprios/as adolescentes e pelas instituições sociais. A construção cultural de concepções homogeneizadoras (que tendem a ignorar as tensões sociais e as condições socioculturais concretas de desenvolvimento do sujeito) influencia fortemente as práticas sociais cotidianas das unidades e/ou programas de atendimento socioeducativo. "Essas macronarrativas normativas sobre quem é o adolescente são internalizadas pelos educadores sociais, de modo a construir socialmente o Outroadolescente como perigoso e digno de disciplinarização" (p. 73). Lopes de Oliveira \& Vieira (2006) complementam a ideia sugerindo que as instituições privativas de liberdade são conduzidas por dois sistemas semióticos: os formais, que constituem as regras e as normas de funcionamento, bem como as hierarquias e os dispositivos de avaliação técnica utilizados; e os não formais, que embora tão presentes quanto os formais, revelam crenças e valores (normalmente influenciados pela mídia e pelo senso comum) sobre a infração juvenil, sendo que esses se revelam por meio dos mecanismos sutis de disciplinarização e da organização institucional. Nesse sentido, ainda de acordo com as autoras, é legítimo supor que o desenvolvimento subjetivo das adolescentes que passam pelo processo de institucionalização ocorre, também, por meio das relações produzidas na interface entre esses dois sistemas. 
Ao longo da Oficina de Reflexão, foram várias as elaborações das adolescentes sobre as práticas institucionais, especificamente, sobre aquelas que deveriam favorecer os processos de desenvolvimento e de mudança de trajetórias de vida:

"Eles falam que isso aqui vai mudar a gente, que a gente vai ficar três anos trancada aqui e que vai mudar. A gente vai sair daqui, e a gente vai chegar lá e não vai ter... não vai ter nada pra... não vai ter um serviço, a gente não vai ter uma faculdade... não vai ter isso, não vai ter aquilo... não vai ter oportunidade de conseguir progredir, e a gente vai voltar a fazer tudo o que a gente fazia antes” (Maria da Penha, 17 anos, 1ano e 5 meses de internação).

Esse trecho apresenta diversos elementos relevantes no que se refere ao processo narrativo de significação da Medida Socioeducativa de Internação.

Já no início de sua narrativa, Maria da Penha utiliza a terceira pessoa do plural (eles) para se referir a um "outro indeterminado" a quem se atribui o "poder" de "mudar" as adolescentes. O emprego do sujeito indeterminado também revela indicadores de um distanciamento entre a instituição (que deveria ser acolhedora e emancipadora) e as adolescentes (protagonistas dos processos de desenvolvimento). A adolescente dá sequência à sua narrativa colocando em xeque a privação de liberdade como contexto promotor de desenvolvimento: "Eles falam que [...] a gente vai ficar três anos trancada aqui e que vai mudar. [...] A gente vai sair daqui, e a gente vai chegar lá e não vai ter... não vai ter isso, não vai ter aquilo... [...] e a gente vai voltar a fazer tudo o que a gente fazia antes.”. As pausas sugerem que ela vai, aos poucos, tomando consciência de que o processo socioeducativo não tem, concretamente, possibilitado novos caminhos. Embora use a primeira pessoa do plural (a gente = nós) para se referir às adolescentes que passam pelo processo socioeducativo, é possível perceber que ela se coloca, simultaneamente, como autora e protagonista de suas reflexões. É interessante notar que ela se refere claramente ao contexto institucional 
como um espaço de efetiva clausura e de ostracismo social: "[...] a gente vai ficar três anos trancada aqui $[\ldots]$ ”.

A preocupação de Maria da Penha com o futuro após o cumprimento da MSE assinala um posicionamento autorreflexivo diante da vida infracional. Os significados que ela atribui à capacitação profisssional (serviço) e à escolarização (faculdade) como possibilidades de mudança de trajetória de vida sugerem um processo de reorganização e de ressignificação dos valores que norteiam as suas escolhas. Entretanto, ela se refere a essa nova trajetória como sendo um caminho desconhecido, longo e indeterminado ( $a$ gente vai chegar lá) que tende a levar a um futuro repleto de interdições e limites (não vai ter isso, não vai ter aquilo...). Esses indicadores evidenciam uma vez mais o distanciamento ainda existente entre os objetivos da ação socioeducativa e a realidade institucional.

Quanto ao processo socioeducativo, é possível perceber que este é significado como um momento de privação total “[...] a gente vai ficar três anos trancada aqui [...]". A ausência de oportunidades de profissionalização configura um impedimento para o desenvolvimento da autonomia e da condição emancipatória, “A gente [...] não vai ter oportunidade de conseguir progredir [...]”. Consequentemente inviabilizando e/ou dificultando a ruptura de uma trajetória de infrações “[...] a gente vai voltar a fazer tudo o que a gente fazia antes." Por fim, suscitando uma imagem que remete a um ciclo de repetição em vez de criação, uma prospecção negativa de futuridade.

Em um contexto especificamente situado como o de uma unidade de Internação, a adolescente privada de liberdade tem restringida a sua convivência com a família e com as pessoas mais próximas. Sendo assim, os diferentes atores sociais com quem interage assumem um importante papel no seu desenvolvimento subjetivo e nos processos de 
significação das experiências cotidianas. Desse modo, as interações que estabelecem no contexto institucional constituem importantes fontes de suporte afetivo. De acordo com Valsiner (2012), “Todas as construções episódicas envolvem sentimento e uma possível reflexão sobre o sentir, mediante o uso de signos" (p. 250). Assim, os significados emergem a partir das experiências pelas quais o sujeito passa como participante ativo em um contexto específico. É possível afirmar que crenças, valores e significados possuem uma base fundamentalmente afetiva. E os significados co-construídos ao longo dos processos de desenvolvimento emergem das interpretações que, criadas de forma dialógica, são negociadas e renegociadas entre os sujeitos em interação (Branco \& Madureira, 2014; Madureira \& Branco, 2012; Valsiner, 2012). Sob essa perspectiva, portanto, as relações de respeito e cooperação, assim como as relações marcadas por conflitos e violência são construídas pelos próprios sujeitos inseridos em contextos situados (Silva \& Maciel, 2014).

A fala de Naomi sobre as diferentes relações com os/as educadores/as sociais ilustra a influência da afetividade nos processos de desenvolvimento subjetivo das adolescentes acauteladas:

"Tem umas pessoas aqui que quer o nosso bem. Eu percebo no modo deles tratar a gente, conversar. Ajuda nós a segurar a onda, a evitar coisa pior. Conversa com nós quando a gente precisa. Aí nós fica de boa, tira a medida sem confusão. Mas em compensação tem umas que instiga a gente pra gente ficar indignada e fazer alguma coisa ruim. Tem umas que gosta de instigar... a gente acorda tranquila, de boa. Aí sabe quando aquela pessoa já chega e te provoca? Aí é treta. Atrasa a nossa medida, a nossa vida... atrasa tudo.”(Naomi, 18 anos, 10 meses de internação).

É interessante notar que Naomi inicia a sua fala procurando não generalizar as mediações realizadas pelos/as educadores/as sociais. Para isso ela faz uma distinção clara entre aqueles/as que incentivam as adolescentes para atitudes positivas (seja conversando ou ajudando a "segurar a onda"), e os/as que contribuem para a emergência 
de comportamentos que as prejudiquem: “[...] tem umas que instiga a gente [...] a fazer alguma coisa ruim.”. Ao empregar um pronome pessoal e um pronome possessivo na primeira pessoa do plural (nós/a gente e nosso/a), ela fala também de suas próprias experiências ao longo do processo socioeducativo: “Aí nós fica de boa [...]” ou "Atrasa a nossa medida [...]". Assim, ela revela indicadores de valores que permeiam as relações sociais no contexto institucional, e que influenciam fortemente no seu desenvolvimento subjetivo. Essa influência é enfatizada quando ela estabelece uma relação entre a medida socioeducativa e sua vida ( medida + vida $=$ tudo $)$.

Consoante Valsiner, Branco \& Dantas (1997) e Branco \& Madureira (2014), os valores, que são especialmente importantes e centrais para o sujeito, são altamente impregnados de afeto e emoção. Nesse sentido, a co-construção de um vínculo afetivo positivo entre adolescentes e educadores/as abre caminho para um contexto favorável aos processos de desenvolvimento. Consequentemente, promover determinados tipos de comportamento em detrimentos de outros pode favorecer (ou inibir) o desenvolvimento saudável dos sujeitos em interação (Branco \& Madureira, 2014).

De acordo com Yokoy de Souza (2007) e Vieira \& Lopes de Oliveira (2013), as unidades de internação muitas vezes deixam de atender propósitos educacionais e seguem a lógica das cadeias, lembrando constantemente a todos que estes não são contextos apropriados para relações próximas de amizade e confiança, mas sim para a dúvida, o receio e a precaução. Compreender o contexto socioeducativo a partir dessa perspectiva nos permite pensar de forma dialética a tensão entre opostos identificada na fala de Naomi. Isso porque, de um lado, estão os/as educadores/as sociais empenhados/as na reinserção social do/a adolescente. De outro, aqueles/as que, muitas vezes motivados por preconceitos e/ou pautados na concepção de uma justiça retributiva (Baratta, 2013), colaboram para a reafirmação de diferentes formas de discriminação e 
de exclusão social. Nesse sentido, é interessante ressaltar que as funções de aconselhamento e estabelecimento de regras e limites (funções normalmente atribuídas aos pais e/ou responsáveis legais) são, nesse contexto específico, desempenhadas principalmente pelos/as educadores/as sociais. Esses/as, por sua vez, como exemplificado na fala de Naomi, podem tanto contribuir para o desenvolvimento de trajetórias de vida divorciadas da prática infracional, como instigar o/a adolescente a atitudes ainda mais agressivas, como é possível perceber também nas falas de Maria da Penha e de Maria Lacerda, respectivamente:

"É disso que a gente precisa, de interesse... alguns têm interesse mesmo de ver a gente lá no alto." (Maria da Penha, 17 anos, 1 ano e 5 meses de internação)

"Eu penso que uma hora eu vou 'matá' uma dessas agentes aí ó. Essas agente (ATRS) deixa eu surtada [expressando bastante raiva em sua voz]. Se uma hora eu passar por essas agentes aí na rua ó... 'véi'... não fala não, mas eu tenho coragem...” (Maria Lacerda, 16 anos, 5 meses de internação).

Os enunciados acima são reveladores da importância da dimensão afetiva nas construções de posicionamentos reflexivos. De um lado, os afetos positivos (interesse), destacados por Maria da Penha; de outro, os negativos (raiva, descontrole, agressividade e violência), que podem contribuir para canalizar posicionamentos e trajetórias. A fala de Maria Lacerda revela um posicionamento subjetivo diante do descontentamento com o tratamento que recebe das ATRS. A narrativa em primeira pessoa do singular ( $\underline{e u}$ penso, $\underline{e u}$ vou, $\underline{e u}$ tenho) indica que ela toma posição sobre fatos que expressam sua dupla condição de sujeito ativo (eu vou) e de produto dos circunscritores culturais que caracterizam o contexto de violência e de marginalização do universo da infração juvenil (eu tenho coragem). Ainda diante dessas duas afirmações, seria possível sugerir que Maria Lacerda reflete sobre a possibilidade de uma reação violenta para expressar a sua insatisfação, chegando a uma conclusão: “[...] 'véi'... não fala não, mas eu tenho coragem...”. 
De acordo com a Resolução 119/2006 - CONANDA, para a qualificação do atendimento socioeducativo são imprescindíveis os alinhamentos conceitual, estratégico e operacional/metodológico da equipe. Para tal, faz-se necessária uma atuação consciente dos/as educadores/as sociais em prol de uma política de atendimento que exija uma postura intransigente no que se refere ao enfrentamento das violações dos direitos dos/as adolescentes acautelados/as. Nesse sentido, cabe essencialmente aos/às educadores/as orientar os/as adolescentes na construção de um projeto de vida mediante o fornecimento de subsídios que os/as elevem à condição emancipatória de cidadãos/ãs.

Assim, é possível traçar um paralelo entre as informações construídas nessa dimensão de análise da pesquisa e o estudo de Silva \& Maciel (2014) sobre a adoção de medidas coercitivas de controle e punição nas escolas, visto que tanto a escola como a instituição socioeducativa são contextos educacionais. Os autores citados argumentam que quando educadores/as e alunos/as não se envolvem na construção coletiva de relações recíprocas de respeito, cooperação e solidariedade, ocorre um clima de mútua ameaça que, normalmente, dá origem a uma série de medidas autoritárias adotadas pela instituição.

A narrativa de Naomi traz aspectos relevantes no que se refere às situações em que medidas disciplinares são indistintamente adotadas pela instituição:

“Eu não posso dar a minha palavra pelas outras, e também não posso ser responsabilizada pelas 'treta ${ }^{, 26}$ das outra. Cada pessoa é cada pessoa, entendeu? Eu sou responsável pelas minha treta, mas aí todo mudo paga por todo mundo. Eu posso tá de boa, com o meu relatório tranquilo, mas se outra pessoa faz alguma coisa, eu rodo também, todo mundo paga. E eu acho isso um lixo... Só de falar eu fico indignada.” (Naomi, 18 anos, 10 meses de internação).

\footnotetext{
${ }^{26}$ Segundo o dicionário informal online, Treta é uma gíria utilizada para se referir a brigas e desentendimentos.
} 
Naomi revela em sua fala como se sente diante das situações em que é responsabilizada pelos erros ("as treta") das colegas. Assim, ela fala de suas experiências de forma fortemente mediada por sentimentos de raiva e revolta. Essa indignação revela, ainda, a tensão presente no relacionamento entre adolescentes e educadores/as sociais, especialmente nos momentos em que a subjetividade do/a adolescente não é considerada (“Cada pessoa é cada pessoa, entendeu?”). Embora ela tenha construído a sua fala utilizando predominantemente a primeira pessoa do singular (eu), em alguns momentos ela deixa evidente que essa é uma realidade compartilhada também pelas demais adolescentes acauteladas: “todo mudo paga por todo mundo.”.

A preocupação dos/as adolescentes com o relatório avaliativo é outra questão muito presente no cotidiano das instituições de internação. Isso porque é com base nesse documento que o/a juiz/a avalia as possibilidades de progressão de medida socioeducativa. Assim, quando Naomi argumenta que mesmo estando com o relatório "tranquilo" (o que em outras palavras quer dizer que ela tem correspondido às expectativas - da sociedade e da própria instituição - de desenvolvimento durante o processo socioeducativo), ela se indigna diante das contradições institucionais, visto que o desenvolvimento do/a adolescente não pode ser pautado em avaliações abstratas. Isso porque, de acordo com a Resolução 119/2006 - CONANDA, para guiar essa avaliação existe o Plano Individual de Atendimento (PIA), documento que "constitui-se numa importante ferramenta no acompanhamento da evolução pessoal e social do adolescente e na conquista de metas e compromissos pactuados com esse adolescente e sua família durante o cumprimento da mediada socioeducativa" (p. 52). Nesse sentido, a sua narrativa retrata a revolta e a impotência dos/as adolescentes diante de como são percebidos o poder e o controle institucional, uma vez que o caráter formativo da 
medida socioeducativa é constantemente atravessado por avaliações abstratas, além de punições e do uso exacerbado da autoridade (Vieira, 2004).

Dessa feita, concordamos com Yokoy de Souza (2007) quando sinaliza algumas características que permeiam a cultura institucional das unidades de medida socioeducativa: pouco reconhecimento das qualidades subjetivas dos/as adolescentes acautelados/as, relações onde prevalece o autoritarismo institucional, e a manutenção da ordem pelo assujeitamento do indivíduo.

Assim, em suma, a análise dos dados relacionados a essa dimensão permitiram compreender que o vínculo afetivo estabelecido entre educadores/as sociais e adolescentes acautelados/as pode influenciar fortemente no desenvolvimento subjetivo e na (co)construção de novas trajetórias de vida para esses/as adolescentes. Ademais, essas narrativas nos sensibilizam para as dificuldades por que passam os/as adolescentes em cumprimento de medida socioeducativa de internação quando têm de lidar com os preconceitos e as discriminações que tomam corpo dentro das próprias instituições socioeducativas.

A infração juvenil, portanto, não deve ser compreendida como um fenômeno isolado ou como resultado de uma deliberação individual, mas como efeito de diversas e inúmeras circunstâncias em que o próprio sujeito, a família, a sociedade e o Estado têm sua parcela de responsabilidade. 


\section{Dimensão 2 - O Olhar das Adolescentes sobre a Instituição Socioeducativa $\leftrightarrow$ O Olhar Institucional sobre a Infração Juvenil Feminina}

“Nós temos os mesmos direitos que os meninos, mas só no papel. Ninguém faz nada pela gente porque eles não querem a gente aqui. E pronto, acabou a história. Nós têm que ficar calada e pronto. Nós é 'esparro'.’(Maria da Penha, 17 anos, 11 meses de internação, em 06/11/2013).

“As pessoas trata nós com indiferença aqui dentro. $E$ isso é de ficar revoltado, por que... não quer dizer que nós estamos presas que a gente vai ser tratado... mal. Que diferença tem de nós pros meninos? Só porque nós somos menores infratoras, mulheres?”(Naomi, 18 anos, 10 meses de internação, em 23/05/2014).

A percepção de que o contexto socioeducativo reproduz as assimetrias de gênero presentes em nossa sociocultura perpassou grande parte dos processos reflexivos ao longo dos encontros da Oficina de Reflexão. A compreensão de que, assim como no contexto social, também no contexto institucional das medidas socioeducativas as adolescentes são alvo de preconceito e discriminação de gênero sustentou inúmeras discussões, especialmente no que se refere à ausência de políticas públicas específicas para o atendimento às adolescentes.

Para essa dimensão de análise, portanto, foram selecionados trechos de narrativas das adolescentes que melhor exemplifiquem a insatisfação delas em relação às crenças, aos valores e às práticas institucionais cotidianas que enfatizam a centralidade do poder masculino no contexto socioeducativo. Todavia, falar sobre essas desigualdades no referido contexto implica trazer à luz concepções e posicionamentos de gênero presentes no macrocontexto social e que penetram o mesocontexto das instituições socioeducativas. 
De acordo com Baratta (1999) ${ }^{27}$, até meados do século XX a infração feminina esteve concatenada aos papéis sociais impostos às mulheres, e os "delitos tipicamente femininos" encontravam acolhimento diferenciado na justiça criminal. Entretanto, com a mudança no perfil desses delitos, especialmente a partir da década de 1970, as punições se asseveraram, uma vez que as “infratoras passaram não apenas a infringir regras penais, mas, sobretudo, a ofender a construção dos papéis de gênero" (p.51). Nesse sentido, com base em uma concepção fortemente marcada por significados assentados em uma visão dicotômica e naturalista da masculinidade e da feminilidade, a justiça criminal - e, por conseguinte, a justiça juvenil - ainda hoje revela traços de uma intervenção pautada em práticas discriminatórias, especialmente no que diz respeito às questões de gênero.

A fala de Maria da Penha, na epígrafe que inicia essa dimensão de análise, pode ser utilizada como referência para ilustrar a percepção que as adolescentes têm de si, especialmente quando inseridas em um contexto fortemente marcado por uma cultura que valoriza o masculino em detrimento do feminino. Cabe ressaltar que, assim como em outras falas suas, ela utiliza a primeira pessoa do plural (nós) para se referir a ela e às adolescentes que estão acauteladas no módulo feminino, assumindo, mais uma vez, o papel de porta voz de si e das demais adolescentes.

Desse modo, ao se referir à (des)igualdade de direitos: "Nós temos os mesmos direitos que os meninos, mas só no papel.”, ela traz à tona a principal reivindicação social e política que permeou os diversos movimentos feministas, iniciados ainda no

\footnotetext{
${ }^{27}$ É importante esclarecer que o autor, em toda a sua obra, tece uma crítica ao modelo de pensamento essencialista em que a compreensão dos significados culturais está estreitamente associada a uma concepção dicotômica - masculino e feminino em oposição - e naturalista sobre os gêneros.
} 
século XIX com manifestações voltadas para estender o direito do voto às mulheres (Louro, 2010). E, ao falar sobre as práticas discriminatórias dessa unidade de internação, chama a atenção para o fato de que, mesmo após décadas de "luta" pela igualdade de direitos entre homens e mulheres, ainda são necessárias transformações culturais e sociais que sejam capazes de sustentar uma real modificação das estruturas hierárquicas de gênero presentes em nossa sociocultura (Louro, 2010; Madureira \& Branco, 2014).

Em seguida, Maria da Penha direciona a sua crítica para o sistema socioeducativo, enfatizando a discriminação e o descaso que vivenciam as adolescentes nesse contexto: “Ninguém faz nada pela gente porque eles não querem a gente aqui.”. Assim, ao justificar o desinteresse institucional pelo público feminino, ela revela as posições latentes entre a igualdade formal defendida pelo sistema de justiça juvenil e a desigualdade substancial a que são submetidas essas adolescentes. O que significa dizer, em outras palavras, que embora o Estado tenha formalizado o seu sistema de justiça juvenil fundamentado na promoção e proteção dos direitos humanos (incluem-se aí a promoção da igualdade e o combate à discriminação, ao preconceito e à desigualdade de gênero), na prática, isso nem sempre se comprova.

Todavia, é interessante notar que, embora ela reproduza em sua fala o que parece ser uma regra implícita da instituição de não se questionar algumas práticas cotidianas: “Nós têm que ficar calada e pronto." , a adolescente utiliza o espaço da Oficina de Reflexão para não "se calar" diante dessas desigualdades, revelando fortes indicadores de rejeição à qualquer sistema de valores institucionais que sustentem formas de discriminação contra as adolescentes. Assim, ela instiga todas as participantes dessa interação dialógica (pesquisadoras e adolescentes) a reflexões ainda mais profundas sobre as desigualdades de gênero que permeiam o processo socioeducativo. Ela finaliza 
a sua fala com o que parece ser mais uma denúncia da discriminação vivenciada pelas adolescentes: "Nós é esparro.". Isso porque, de acordo com o dicionário informal online $^{28}$, esparro é uma gíria utilizada para se referir a alguma situação comprometedora, ou a alguém cuja imagem pessoal compromete a imagem de outro alguém.

Assim como Maria da Penha, Naomi também traz em sua fala denúncias contra uma ideologia institucional que prioriza a atenção aos adolescentes em detrimento da atenção às adolescentes. Ao se referir ao modo (in)diferente como são tratadas as adolescentes, ela expressa claramente o seu descontentamento em relação às desigualdades de gênero no atendimento: “E isso é de ficar revoltado, [...]”. A adolescente dá continuidade à sua reflexão procurando explicar os motivos pelos quais não concorda com tal (in)diferença. As pausas em sua fala sugerem que ela, aos poucos, toma consciência de que as adolescentes não apenas são tratadas de maneira indiferente dentro da instituição socioeducativa, mas que essa (in)diferença pode significar, também, que são mal tratadas. É interessante notar que Naomi, a princípio, atribui essa (in)diferença no tratamento dispensado às adolescentes ao fato de estarem presas: “[...] quer dizer que nós estamos presas que a gente vai ser tratado...”. Entretanto, ela em seguida emenda com um questionamento que revela, novamente, uma discriminação de gênero: “Que diferença tem de nós para os meninos?” Assim, finaliza a sua reflexão: “Só porque nós somos menores infratoras, mulheres?" trazendo à tona questões que são centrais para esse estudo: a discriminação da adolescente que comete ato infracional e a consequente invisibilização da infração juvenil feminina.

A reprodução de políticas de discriminação de gênero dentro da instituição socioeducativa, ao diferenciar hierarquicamente as adolescentes dos adolescentes, 
reafirma os papéis de gênero socialmente construídos (Ramos, 2010). Nesse sentido, o papel social secundário, imposto e vivenciado pelas mulheres em nossa sociedade, ainda nos dias atuais, atinge também o sistema de justiça juvenil, institucionalizando as desigualdades e a consequente opressão de gênero. Desse modo, é possível sugerir que a invisibilização da infração juvenil feminina advém muito mais do sexismo (relações assimétricas de gênero) presente em nossa sociocultura, do que da menor quantidade de delitos cometidos por adolescentes do sexo feminino (Faccio \& Camacho, 1995).

A fala de Maria da Penha exemplifica a invisibilização institucional e social que vivenciam as adolescentes que cometem atos infracionais:

“Nós somos esquecidas pelo sistema, pela justiça... ninguém olha pra nós. Nós só fica aqui presa. Isso é uma forma de isolar a gente.” (Maria da Penha, 17 anos, 11 meses de internação).

Assim, esse trecho de sua narrativa revela indicadores de que as adolescentes acauteladas sofrem diferentes formas de discriminação e de exclusão social (esquecidas pelo sistema, pela justiça, por todos). Nesse sentido, o isolamento a que se refere Maria da Penha reflete não somente o preconceito social e a discriminação de gênero, mas também "[...] uma rede de significação coletiva e dos sistemas semióticos não formais que podem contribuir para manter o sujeito numa trajetória desenvolvimental carregada de preconceitos e de concepções tão arraigadas sobre a autoria de infração que sustentam a ideia de que uma vez infrator, sempre infrator" (Vieira \& Lopes de Oliveira, 2013, p. 175). Desse modo, a internação funciona, portanto, como dispositivo de exclusão que distancia as adolescentes dos olhos da sociedade.

Todavia, conforme mencionamos no início da seção, Baratta (1999) chama a atenção para outro fenômeno fortemente presente quando se trata da infração feminina, qual seja a maior severidade com que são tratadas as mulheres no sistema penal e as 
adolescentes no sistema de justiça juvenil. Nesse sentido, no que se refere à discriminação de gênero, é possível sugerir que a infração juvenil feminina apresenta duas faces de uma mesma moeda. Por um lado as adolescentes lidam com a indiferença da instituição socioeducativa, especialmente em relação às possibilidades concretas de desenvolvimento e de mudança de trajetórias de vida e, por outro, têm de lidar, muitas vezes, com medidas (disciplinares, de segurança, etc.) mais rigorosas do que os adolescentes. Consoante Baratta (1999), Espinoza (2002) e Ramos (2010), no que tange às mulheres, o sistema de justiça criminal (e, por conseguinte, o sistema de justiça juvenil) é ainda mais rígido, visto que reproduz a discriminação de gênero ainda presente em nossa sociocultura. Assim, pune duplamente a mulher e/ou a adolescente que comete delitos, seja por meio do controle formal do poder judiciário, seja por meio do controle informal da sociedade.

As falas de Maria da Penha e Rose Marie, a seguir, exemplificam a lógica repressora utilizada no sistema socioeducativo. Em outras palavras, isso significa dizer que o sistema socioeducativo, embora em sua composição legal e constitucional não tenha um caráter punitivo, mas sim educativo, na prática ainda se mostra como um sistema de punição retributiva. Isso porque permanece seguindo a mesma lógica de segurança, tratamento arbitrário e violação de direitos dos sistemas prisionais (Ramos, 2013). Nesse sentido, tornam-se legítimas as comparações entre o sistema de justiça juvenil e o sistema de justiça criminal.

"Eles quer tratar nós que nem se nós tivesse no sistema prisional. A gente tem que andar de mão pra trás e cabeça baixa. Olhando pro chão. Não pode nem conversar com eles (ATRS). As pessoas fala que aqui é o socioeducativo, mas as pessoas não são educadas com a gente.” (Maria da Penha, 17 anos, 11 meses de internação). 
“Eles acha que aqui é a COLMEIA ${ }^{29}$." (Rose Marie, 19 anos, 1 ano e 3 meses de internação).

É interessante notar como as narrativas de Maria da Penha e Rose Marie ilustram alguns dos mecanismos de controle institucional utilizados com os/as adolescentes: mão pra trás e cabeça baixa, olhando para o chão. No caso, ela demonstra reconhecer a dimensão punitiva que incide sobre o corpo, que se busca disciplinar e, desse modo, controlar as ações, as interações e a comunicação.

Outra questão igualmente relevante que aparece na fala de Maria da Penha se refere às possibilidades concretas e à qualidade das interações ao longo do processo socioeducativo: “[...]as pessoas não são educadas com a gente.”. Quando ela diz: "Não pode nem conversar com eles (ATRS).”, indica que as normas institucionais são muitas vezes pautadas em práticas que não valorizam - e até mesmo desencorajam - as interações entre educadores/as e adolescentes. Nesse sentido, o sistema socioeducativo acaba por punir as adolescentes, seja por meio da crescente repressão institucional ou das barreiras sociais (preconceito e discriminação) que dificultam o desenvolvimento de trajetórias de vida divorciadas das práticas infracionais.

Todavia, de acordo com a Resolução 119/2006 do CONANDA, a Medida Socioeducativa deve contribuir para o desenvolvimento pleno da/do adolescente, "propiciando o acesso a direitos e às oportunidades de superação de sua situação de exclusão, de ressignificação de valores, bem como o acesso à formação de valores para a participação na vida social [...]” (p. 46, grifo nosso). A Declaração Universal dos Direitos Humanos, por sua vez, legitimou valores que foram adotados por inúmeros diplomas, sistemas e ordenamentos jurídicos. Liberdade, solidariedade, justiça social, responsabilidade e respeito à diversidade são alguns dos valores norteadores de uma

\footnotetext{
${ }^{29}$ Colmeia é o nome popular que se dá à Penitenciária Feminina do Distrito Federal - PFDF
} 
prática que garante a todos o direito de pessoa humana. Desta feita, a atendimento socioeducativo tem o dever de garantir ao/à adolescente o seu reconhecimento “[...] como sujeito pertencente a uma coletividade que também deve compartilhar esses valores” (Resolução 119/2006 do CONANDA, p. 23).

Outro aspecto muito presente nas reflexões das adolescentes durante os encontros da Oficina de Reflexão se refere ao estereótipo da mulher encrenqueira, emotiva e barulhenta que tem sido legitimado na cultura brasileira e reproduzido no contexto socioeducativo. Essa legitimação se revela por meio de diferentes dispositivos culturais, seja pelo senso comum, pelos meios de comunicação, ou pela manutenção de ideologias patriarcais hierárquicas e sexistas (Fávero, 2010; Mendes, 2014). De acordo com Fávero (2010) “[...] podemos dizer que, seja por meio da mídia ou na escola, ou nas nossas relações interpessoais, estabelece-se um paradoxo exemplar: não se faz referência ao patriarcado ${ }^{30}$ nem às suas premissas, mas seus significados são mediados e por isso mesmo ele é mantido" (p.74).

As Ciências Humanas têm sido palco de diversos estudos sobre os significados culturais associados às masculinidades e às feminilidades. Nesse sentido, tem sido grande o esforço para a explicação do caráter multifacetado da sexualidade, onde se encontram vinculados os valores, as crenças, as relações de poder e as práticas sociais e institucionais que permeiam os diferentes contextos sócio-histórico-culturais nos quais os sujeitos se desenvolvem (Louro, 1997, 2010; Madureira, 2007; Madureira \& Branco, 2012, 2014).

Não obstante o essencialismo biológico presente no modelo biomédico, o conceito de gênero apresenta um grande avanço nos estudos interdisciplinares sobre as

\footnotetext{
${ }^{30}$ Podemos dizer, em poucas palavras e de maneira bastante resumida, que o Patriarcado se refere à hierarquia entre homens e mulheres, entretanto, com primazia masculina. Para um aprofundamento do conceito, consultar: Fávero, 2010; Mendes, 2014.
} 
masculinidades e as feminilidades. Isso porque enfatiza a dimensão cultural presente no processo contínuo de tornar-se homem ou mulher (Madureira \& Branco, 2014), funcionando, portanto, como uma ferramenta ao mesmo tempo analítica e política (Louro, 2010, Scott, 1995). Ademais, os estudos de gênero orientados pela perspectiva da psicologia sociocultural enfatizam a necessidade de uma visão crítica em relação às matrizes universalizantes e descontextualizadas sobre os fenômenos sociais e psicológicos. Conferindo, portanto, centralidade à cultura nos processos de desenvolvimento subjetivo dos sujeitos (Madureira \& Branco, 2014; Valsiner, 2012).

Entretanto, cabe a reflexão de que a mudança de posição das mulheres em termos sociais e econômicos - decorrente dos estudos e dos movimentos feministas que têm como objetivo comum o fim da opressão feminina - ainda não se configurou como suficientemente forte para o efetivo rompimento com as ideologias que reservam às mulheres posições sociais inferiores e, não raro, de subordinação em relação aos homens.

Desse modo, as relações de gênero que refletem as formas de ordenação de direitos em contextos situados encontram nas instituições socioeducativas condições propícias para a manutenção das desigualdades de gênero sustentadas em relações desiguais de poder. Os trechos a seguir, extraídos de narrativas das adolescentes participantes dessa pesquisa, exemplificam situações em que é possível perceber indicadores de assimetrias de gênero no cotidiano das unidades de internação:

“Os meninos podem ficar tudo junto no banho de sol, e nós não.” (Maria da Penha, 17 anos, 11 meses de internação).

"Eles dizem que mulher briga demais. Mas é que todo mundo aqui considera o módulo feminino o pior módulo. Que a gente... sei lá, moço... as pessoas têm muito preconceito com a gente porque a gente é mulher, entendeu... aqui, a gente, mulheres, não tem direito de nada...” (Naomi, 18 anos, 5 meses de internação). 
Os dois trechos selecionados exemplificam situações concretas, vivenciadas pelas adolescentes no contexto institucional, de reprodução de concepções negativas e estereotipadas sobre as adolescentes que cometem atos infracionais. No primeiro deles, Maria da Penha inicia a sua fala exemplificando uma situação em que ela percebeu que as normas institucionais são diferentes para os módulos masculinos e o módulo feminino, sendo que essas normas se mostram desvantajosas apenas para as adolescentes. Relevante se faz notar que, ao se referir ao conjunto de adolescentes acautelados na instituição, ela incorre na reprodução do pensamento dicotômico que coloca em lados opostos o masculino (os meninos) e o feminino (nós). Naomi complementa a fala de Maria da Penha trazendo elementos distintos de análise que nos permitem enxergar a reprodução de alguns estereótipos de gênero que permeiam as relações e as normas institucionais. Esses rótulos, entretanto, referem-se não somente às mulheres de um modo geral: “Eles dizem que mulher briga demais.”, mas também às adolescentes que cumprem medidas socioeducativas: “Mas é que todo mundo aqui considera o módulo feminino o pior módulo.”. É interessante chamar a atenção para o fato de que quando Naomi faz referência ao preconceito em relação ao módulo feminino dentro da unidade, ela deixa pistas para que se compreenda que a sua percepção é a de que essa é uma opinião compartilhada por todos/as na instituição: “[...] todo mundo aqui [...].”. Assim, na medida em que desenvolve a sua reflexão, ela deixa de reproduzir o que parece ser o olhar institucional sobre as adolescentes, para assumir um posicionamento diante de tais atitudes discriminatórias: “[...] as pessoas têm muito preconceito com a gente porque a gente é mulher [...]”. Em seguida, reafirma a sua percepção acerca do tratamento desigual entre adolescentes do sexo masculino e adolescentes do sexo feminino na instituição: “aqui, a gente, mulheres, não tem direito de nada...”. 
Face ao exposto, é possível perceber indicadores de que a instituição socioeducativa, em algumas situações, não só legitima a reprodução de estereótipos de gênero, como também contribui para a manutenção de ideologias sexistas. Todavia, cabe ressaltar, as assimetrias de gênero identificadas no atendimento socioeducativo refletem a condição de discriminação e opressão, das mulheres, existentes em nossa sociocultura. Imperativo se faz, portanto, que cultivemos uma atitude crítica em relação aos significados culturais que permeiam as práticas cotidianas, em especial aquelas que se referem ao processo de inclusão/exclusão que essas adolescentes vivenciam no cotidiano das relações sociais e das normas institucionais estabelecidas no contexto do atendimento socioeducativo.

\section{Dimensão 3 - Interação $\leftrightarrow$ Social Isolamento}

“Mas velho, eu não entendo pra quê isolar a gente... a gente não tá aqui pra se ressocializar? Pra voltar a conviver com a sociedade? Então a gente tem que começar com quem tá aqui dentro, não sozinha... inclusive com os meninos. Eles acham que a gente vai sair daqui e vai se isolar no mundo? (Maria da Penha, 17 anos, 1 ano e 05 meses de internação, em 23/05/2014)

“Eles quer ressocializar nós trancada, igual bicho? Só cria mais ódio em nós, o dia todo trancada ali. Isso aqui não ressocializa ninguém não, moço [expressando raiva em sua voz]. Só alimenta o ódio, a raiva...” (Judith, 20 anos, 11 meses de internação, em 23/05/2014)

As significações sobre os contextos de interação entre as/os adolescentes acautelados em instituições privativas de liberdade estiveram presentes em grande parte das interações comunicativas que aconteceram ao longo da Oficina de Reflexão. As narrativas das adolescentes revelaram indicadores de que existe um processo reflexivo 
em curso acerca das práticas institucionais e, nessa dimensão de análise especificamente, sobre aquelas que deveriam favorecer os processos de desenvolvimento das/dos adolescentes por meio das interações interpessoais.

A fala de Maria da Penha (na epígrafe que inicia a seção) ilustra a importância e o significado atribuídos à convivência em grupo e às interações no que se refere aos processos de desenvolvimento e de reinserção social da adolescente que cumpre MSE de Internação: “[...] eu não entendo pra quê isolar a gente... a gente não tá aqui pra se ressocializar? Pra voltar a conviver com a sociedade?”. Sua narrativa também expressa o reconhecimento da função pedagógica da medida socioeducativa, ao mesmo tempo em que revela a tensão existente entre o que está previsto no Sistema de Garantia de Direitos e aquilo que é de fato posto em prática nas instituições de medida socioeducativa. Quando diz "Então a gente tem que começar com quem tá aqui dentro, não sozinha...” Maria da Penha marca uma tomada de posição ao compartilhar com os educadores sociais a responsabilidade sobre o seu processo socioeducativo, enfatizando a qualidade de sujeito reflexivo e ativo no seu próprio desenvolvimento.

O isolamento e o pouco convívio social, por sua vez, podem suscitar sentimentos ruins e significações negativas em relação à medida socioeducativa, como é possível perceber na narrativa de Judith, na segunda epígrafe que inicia esta seção: “[...] Só cria mais ódio em nós, o dia todo trancada ali. Isso aqui não ressocializa ninguém não, moço. Só alimenta o ódio, a raiva...”. Judith utiliza expressões (ódio, raiva) que revelam nitidamente sua insatisfação e incredulidade em relação à medida socioeducativa “Isso aqui não ressocializa ninguém não [...].” Assim como Maria da Penha, Judith enfatiza que o isolamento não pode ser caracterizado como educativo e/ou pedagógico. Ao comparar a situação de isolamento social da adolescente em cumprimento de medida de internação à condição de um animal que vive "trancado", 
ela reafirma a sua compreensão de que a "ressocialização" pressupõe interação social e trocas intersubjetivas: “Eles quer ressocializar nós trancada, igual bicho?”.

De acordo com o artigo 121 do ECA, a MSE de Internação constitui medida privativa de liberdade, sujeita aos princípios de brevidade, excepcionalidade e respeito à condição peculiar de pessoa em desenvolvimento. Esses princípios são complementares e estão fundamentados na premissa de que o cumprimento da medida não pode ocorrer em situação de isolamento e de privação social do/da adolescente. Nesse sentido, a garantia da prevalência do aspecto pedagógico da MSE, sobre o repressivo, pressupõe algumas condições imprescindíveis de respeito ao/à adolescente acautelado/a. Sendo assim, durante o período de internação devem ser assegurados, portanto, o direito à convivência familiar e comunitária e às atividades pedagógicas, como escolarização, profissionalização e atividades culturais, esportivas e de lazer. Isso posto, não há como conceber o processo socioeducativo divorciado de práticas que impliquem interação interpessoal.

Sob a perspectiva sociocultural do desenvolvimento, a adolescência é uma fase em que as trocas intersubjetivas passam a exercer significativa influência no desenvolvimento subjetivo (Castro \& Besset, 2008; Lopes de Oliveira, 2006; Lopes de Oliveira \& Vieira, 2006). Com o grupo de amigos/as o/a adolescente fortalece suas relações extrafamiliares, e a partir, também, dessas interações ele/a amplia e diversifica a sua rede de relações sociais e de significações. De acordo com Braconnier \& Marcelli (1998), essa interação responde à necessidade do/a adolescente de sentir-se integrado ao seu contexto social, e à possibilidade de ressignificação de crenças, valores e normas culturais. 
Divergindo dessa perspectiva, os dados revelaram indicadores de que as duas instituições em que ocorreram os encontros da Oficina de Reflexão têm como norma a concessão de espaço restrito para as interações interpessoais tanto na Unidade (como um todo), como dentro do módulo feminino: “A gente não se encontra no módulo, só se encontra na escola e na Oficina... e mesmo assim nem são todas. Depende de quem é da sala." (Rose Marie, 19 anos, 1 ano e 3 meses de internação). Nesse sentido, as adolescentes manifestaram insatisfação com as regras institucionais que limitam a interação não somente entre elas, mas também delas e os demais adolescentes que estão na instituição:

"Ia ter mais novidade se a gente convivesse com pessoas de outros módulos. Os meninos convivem com meninos de outros módulos. Mas a gente... nada...” (Naomi, 18 anos, 1 anos e 05 meses de internação).

A narrativa supracitada é um bom exemplo para ilustrar como normalmente se dão as condições concretas de interação na unidade de internação. Aos meninos é dada a oportunidade de interação entre os adolescentes de diferentes módulos, seja na escola, nas oficinas profissionalizantes ou durante as atividades de lazer. Já as adolescentes, de acordo com suas falas, não usufruem desse mesmo "privilégio".

Outro aspecto igualmente revelador que emergiu em várias narrativas se refere às raras oportunidades de negociação das diferenças entre as adolescentes, visto que, segundo elas, a medida adotada pela instituição é a de isolá-las ao primeiro sinal de briga e/ou desentendimento:

“A gente já 'tirou’ o banho de sol juntas. Só separava as maiores das menores. Mas aí as menina brigaram, puxaram cabelo... aí cortaram. Agora é que nem na outra unidade, só por quarto e fim de papo.” (Chiquinha, 16 anos, 1 ano e 11 meses de internação). 
Cabe ressaltar que, no contexto específico de privação de liberdade, os momentos de interação entre as adolescentes, embora ainda muito restritos, representam importantes espaços para a negociação das normas e dos valores institucionais. De acordo com a perspectiva dialógica, os processos de significação e de ressignificação acontecem a partir da interação entre o sujeito e o contexto no qual se desenvolve. Situações concretas de interações interpessoais constituem, portanto, um cenário para a (re)negociação dos significados e dos valores sociais (Yokoy de Souza, 2012).

Por fim, há de se considerar que os conflitos e os desentendimentos podem suscitar rupturas que propiciem reflexões e escolhas de novas trajetórias de vida. Nesse sentido, os processos reflexivos e de ressignificação podem funcionar como promotores de desenvolvimento na medida em que permitem aos sujeitos atribuir novos sentidos às suas ações.

A Oficina de Reflexão foi apontada pelas próprias adolescentes como um importante (e raro) momento para a renegociação das diferenças. Isso porque criou um espaço de fala (aparentemente inexistente nesse contexto) que possibilitou a interação entre elas e a discussão acerca das normas e dos valores que orientam as práticas institucionais cotidianas. Em outras palavras, o processo dialógico e a atividade narrativa suscitaram processos reflexivos que resultaram na resolução de alguns conflitos.

Os dados dessa dimensão de análise sugerem que as instituições e/ou programas de execução de MSE considerem a importância das interações interpessoais no desenvolvimento subjetivo das adolescentes acauteladas. Isso porque a interação e as trocas subjetivas são intrínsecas ao desenvolvimento do sujeito, visto que os processos 
reflexivos e de ressignificação de concepções e de valores emergem nos contextos de interação.

\section{Dimensão 4 - Processos Reflexivos $\leftrightarrow$ Reprodução do Discurso Institucional.}

Episódio: "A maioria aqui se gosta, mas direto rola 'guerra ${ }^{31,} . "$

Data: $26 / 11 / 2013$

Local: Sala de aula do bloco A da Escola da UNIRE

Participaram do encontroa pesquisadora e as adolescentes Sandra, Guacira, Maria da Penha, Judith, Chiquinha, Rose Marie e Naomi.

Participaram da sequência, aqui apresentada em forma de episódio, a pesquisadora e as adolescentes Naomi, Chiquinha e Rose Marie.

Contextualização do episódio:

O episódio a seguir foi extraído do encontro $n^{\circ} 04$ da Oficina de Reflexão, que teve como objetivo a reflexão e a discussão sobre as relações entre as adolescentes no contexto dessa Unidade de Internação, visto que no segundo encontro as adolescentes já haviam falado sobre as poucas oportunidades de interação entre elas. A pesquisadora e as adolescentes se acomodaram em carteiras universitárias. Seguindo uma dinâmica de "roda de prosa", as adolescentes começaram a falar a partir da pergunta disparadora: "Meninas, vocês poderiam falar um pouco sobre a relação de vocês, umas com as outras, aqui dentro da Unidade?”.

\footnotetext{
${ }^{31}$ Brigas, intrigas e desentendimentos.
} 
$\mathrm{Na}$ apresentação abaixo, as sequências de enunciados das participantes são intercaladas com comentários, interpretações e análises da pesquisadora.

A sequência aconteceu entre três meninas, sendo duas maiores (Naomi e Rose Marie) e uma menor (Chiquinha) de idade.

(T 01) Pesquisadora: Meninas, vocês poderiam falar um pouco sobre a relação de vocês, umas com as outras, aqui dentro da Unidade?

(T 02) Naomi: A maioria aqui se gosta, mas direto rola "guerra".

(T 03) Pesquisadora: E quais são os motivos das "guerras"?

(T 04) Chiquinha: É muita mulher junta, aí rola "guerra".

(T 05) Rose Marie: Não acho que é isso não. Acho que é porque não tem respeito entre todas.

(T 06) Naomi: Eu também acho, principalmente entre as menores.

A pergunta da pesquisadora em T03 propicia uma tomada de perspectiva das duas adolescentes maiores de idade, ao problematizar o fato de que o desrespeito entre as adolescentes do módulo feminino é uma prática comum para as adolescentes menores de idade. A sequência do diálogo cria condições para a assunção de perspectivas mais reflexivas:

(T 07) Rose Marie: Posso até dar um exemplo: quando vocês menores briga, vocês faz o maior escarcéu. Não quer saber se tem alguém dormindo, passando mal, ou o que for. Sem contar quando vocês começa a bater na lata ${ }^{32}$.

(T 08) Naomi: "Aí é treta pra todo mundo. Ou vocês acha que as agente tá preocupada com quem não tá aprontando?"

(T 09) Rose Marie: "Aí roda tudo junto, vai tudo pro castigo."

\footnotetext{
${ }^{32}$ Nesse contexto, bater na lata significa batucar nas portas de ferro que fecham os quartos, com a intenção de fazer barulho.
} 
A narrativa de Naomi em T08 traz à luz algumas especificidades do atendimento socioeducativo, especialmente no que se refere às normas disciplinares dentro do módulo feminino. As adolescentes continuam o diálogo:

(T 10) Chiquinha: "É, mas na hora da raiva ninguém pensa".

(T 11) Rose Marie: "Mas tem que pensar. Você não pode colocar os outro nas suas treta. Você tem que ser mulher e assumir as suas treta sozinha".

Nota-se que a partir da fala de Rose Marie em T11, a discussão deixa de ser uma troca de acusações e passa a assumir contornos de uma renegociação acerca das normas de convivência dentro do módulo feminino. A sequência narrativa revela indicadores de que a Oficina de Reflexão possibilitou essa renegociação:

(T 12) Chiquinha: "Mas vocês nunca tinha falado isso pra mim, não assim desse jeito".

(T 13) Naomi: "Nós tamo falando agora."

(T 14) Rose Marie: "Nós não tinha a oportunidade de conversar entre nós e de resolver as treta, assim como tamo conversando agora. É uma oportunidade que nós tá tendo de se acertar."

(T 15) Naomi: "E na hora da raiva, ninguém dá conselho, é só sangue no olho".

(T 16) Chiquinha: "Mas vocês mal fala comigo...".

(T 17) Rose Marie: "Mas tamo falando agora. É uma oportunidade que nós tá dando pra você".

(T 18) Chiquinha: "Eu nunca tinha pensado nisso, que vocês não falava comigo por causa disso. Eu achei que vocês simplesmente não gostava de mim e pronto. Agora que eu sei, eu vou pensar antes de meter os outro nas minha treta, mesmo".

Esse episódio tem distintos elementos significativos no que se refere ao processo de ressignificação das relações interpessoais no contexto do módulo feminino. Isso 
porque a proposta de diálogo tal como sugerida pela pesquisadora em T1: "Meninas, vocês poderiam falar um pouco sobre a relação de vocês, umas com as outras, aqui dentro da Unidade?”, junto com a própria dinâmica da atividade propiciam uma transição de significados que se desenvolve ao longo da interação.

O episódio inicia-se com Naomi argumentando, em T2, que embora as adolescentes gostem umas das outras, os desentendimentos entre elas são frequentes. Chiquinha dá continuidade ao diálogo justificando as diferenças e as brigas como consequências de um comportamento "natural" do sexo feminino: "É muita mulher junta, aí rola guerra.”. Essa assunção de Chiquinha, em T4, representa claramente algumas das generalizações preconceituosas e estereotipadas, sobre o gênero feminino, presentes nas macronarrativas sociais e reproduzidas no contexto institucional. De acordo com as perspectivas que tendem à naturalização dos papéis de gênero, a expressão emocional é uma característica predominantemente feminina. Instintiva e incontrolável, na mulher, a exacerbação dos sentimentos se tornaria um empecilho ao pensamento racional. Desse modo, a reprodução dessa perspectiva no contexto institucional, além de dificultar os processos reflexivos, reserva às adolescentes uma posição de menor valor social, visto que, de acordo com Fávero (2010), a nossa cultura ocidental valoriza a razão em detrimento da emoção.

Dando sequência ao diálogo, Rose Marie, em T5: "Não acho que é isso não. Acho que é porque não tem um respeito entre todas.”, e Naomi, em T6: “Eu também acho, principalmente entre as menores.”, assumem uma posição discursiva convergente e complementar, que se repete em algumas sequências ao longo da interação. Todavia, embora essa posição incorra em uma desconstrução dos estereótipos de gênero, ela revela - assim como a narrativa de Chiquinha em T4 - indicadores de uma reprodução da cultura institucional que, nesse caso, fomenta a hierarquização das diferenças entre 
os grupos de adolescentes maiores e menores de idade. Nesse sentido, é possível sugerir que o desenvolvimento subjetivo das adolescentes que cumprem medida socioeducativa de internação é permeado por mediações sócio-histórico-culturais e institucionais que são normalmente perpassadas por concepções deterministas e generalizantes que tendem a naturalizar comportamentos.

Note-se que, até então, as falas das três adolescentes são indicadoras de dois posicionamentos discursivos em oposição. Rose Marie e Naomi, de um lado, representam o grupo das adolescentes maiores de idade, enquanto Chiquinha, sozinha, aparece como uma representante do grupo das adolescentes menores de idade. Inicialmente, os significados trazidos à tona por Rose Marie e Naomi em T5 e T6, referem-se ao "outro indeterminado", na forma da $3^{\text {a }}$ pessoa do plural - elas, as meninas menores de idade. Em T7, Rose Marie, direcionando a fala para Chiquinha, passa a incluí-la no grupo das menores: "Quando vocês menores briga, vocês faz o maior escarcéu. [...] Sem contar quando vocês começa a bater na lata.”. Nesse momento, Rose Marie e Naomi assumem uma posição de "outro" em relação a Chiquinha, reproduzindo fortemente o discurso institucional de que o módulo feminino é dividido em dois grupos distintos e rivais. Todavia, em T8, Naomi traz à tona a questão de que, embora exista essa divisão, quando se tratam de castigos e punições, essa divisão desaparece, dando lugar a outro nível de hierarquia, que se expressa na relação entre as ATRS e as adolescentes: T8 - "Aí é treta pra todo mundo. Ou vocês acha que as agente tá preocupada com quem não tá aprontando?”. Desse modo, é possível falar, novamente, nos dispositivos semióticos formais e não formais presentes nas práticas cotidianas das instituições de privação de liberdade (Lopes de Oliveira \& Vieira, 2006).

Ao longo da interação dialógica é possível perceber que a intencionalidade das falas de Rose Marie e Naomi se transforma. Ora referem-se à Chiquinha como 
representante do grupo das adolescentes menores de idade (vocês, em T7 e T8), ora a ela na sua subjetividade (você, em T11 e T17). Desse modo, podemos perceber que os significados lançados por Rose Marie e Naomi vão aos poucos impactando subjetivamente Chiquinha, resultando quer em rejeição do posicionamento de Rose Marie e Naomi como interlocutoras: T 12 - "Mas vocês nunca tinha falado isso pra mim, não assim desse jeito”, quer na rejeição da afirmação de que somente as adolescentes menores de idade são irreflexivas: T 10 - “É, mas na hora da raiva ninguém pensa”. Ainda em T10, quando diz: ninguém pensa, é possível perceber indicadores de que Chiquinha insiste na concepção generalizante de que nos momentos de animosidade todas as adolescentes são igualmente dominadas por emoções que as impossibilitam de tomar decisões racionais. De acordo com Lopes de Oliveira (2006), toda enunciação produz efeitos não só em quem fala e quem escuta, mas também no contexto em que a interação ocorre. Nesse sentido, traduz "[...] simultaneamente quem fala e aquilo sobre o que fala, por meio de dispositivos discursivos e metacomunicativos específicos” (Lopes de Oliveira \& Vieira, 2006, p. 75).

É interessante notar que em T14, a narrativa de Rose Marie assume uma perspectiva que segue no caminho contrário ao que vinha sendo visto até então. Isso porque Rose Marie emprega a primeira pessoa do plural (nós) para se referir às adolescentes do módulo feminino como pertencentes a um só grupo. A divisão entre dois grupos distintos cede lugar a um único grupo, que partilha das mesmas dificuldades de condições concretas de interação e de renegociação das regras de convivência dentro do módulo: T 14 - “Nós não tinha a oportunidade de conversar entre nós e de resolver as treta, assim como tamo conversando agora. É uma oportunidade que nós tá tendo de se acertar." 
A partir de T16 é possível perceber que Chiquinha passa a falar de si: "Mas vocês mal fala comigo...”, revelando indicadores de um posicionamento subjetivo, por meio do qual é possível assumir um lugar inferior em relação às outras adolescentes do "grupo das menores". Nesse sentido, suas falas (em T16 e T18) são indicadoras de um reposicionamento subjetivo, onde significados são negociados, resultando em um processo de tomada de consciência por Chiquinha: T18 - "Eu nunca tinha pensado nisso, que vocês não falava comigo por causa disso. Eu achei que vocês simplesmente não gostava de mim e pronto. Agora que eu sei, eu vou pensar antes de meter os outro nas minha treta, mesmo.”. Assim, interpelada pelos significados trazidos à tona pela interação narrativa, Chiquinha tem a possibilidade de construir novos sentidos sobre si e também sobre as outras adolescentes, visto que é por meio das trocas entre os sujeitos que compartilham uma realidade social, que conhecimento e subjetividade se produzem (Lopes de Oliveira, 2003). A conscientização do erro e a promessa de pensar nas demais colegas revelam haver uma ressignificação de Chiquinha sobre as relações interpessoais no módulo feminino. Consoante Vieira \& Lopes de Oliveira (2013) é possível supor que uma experiência seja promotora de desenvolvimento quando por meio dela o sujeito consegue reinserir em suas autorrepresentações um sentido de temporalidade e processo, e regular os processos de ressignificação de modo a contemplar a futuridade, orientando-se para diferentes possibilidades e novas trajetórias de desenvolvimento.

O episódio analisado ilustra o processo de negociação pactuado entre as adolescentes. Os confrontos estabelecidos ao longo das negociações revelam-se como parte do processo de construção subjetiva na relação do sujeito com a alteridade e com o contexto no qual se desenvolve. Um jogo de posicionamentos é revelado ao longo da dinâmica interativa, visto que as adolescentes negociam o seu pertencimento (ou não) a um determinado grupo, bem como as diversidades aí implicadas. Assim, nesse 
movimento de continuidade e descontinuidade de posicionamentos, as adolescentes atribuem sentidos e significados ao contexto em que estão inseridas e às suas próprias ações, num processo de ressignificação de si e desse contexto. Nesse sentido, as contradições que emergem dessa interação refletem os movimentos intersubjetivos de permanência e mudança, característicos dos processos de desenvolvimento humano (Vieira \& Lopes de Oliveira, 2013).

Os circunscritores culturais presentes no contexto socioeducativo são percebidos nas falas das adolescentes quando reproduzem os discursos institucionais - seja em relação às questões de gênero ou à divisão das adolescentes em grupos hierarquicamente diferentes. Nesse sentido, há de se considerar que as narrativas produzidas e desenvolvidas nesse espaço são perpassadas pelas características (normas e valores) desse contexto específico. Todavia, as tensões e ambiguidades presentes nas narrativas das adolescentes indicam haver uma reação à normatização institucional, e essa reação, por sua vez, revela a existência dos processos reflexivos, que são característicos do sujeito dialógico e relacional.

De acordo com a perspectiva sociocultural, os processos de desenvolvimento humano implicam uma complexidade de elementos que interagem e influenciam no desenvolvimento subjetivo (Valsiner, 2012). Entretanto, torna-se imperativo conhecer o contexto em que se desenvolve o sujeito para que possamos compreender suas ações, seus posicionamentos e a maneira pela qual estabelecem relações com os seus pares (Vieira \& Lopes de Oliveira, 2013). Nesse sentido, os processos reflexivos das adolescentes, nesse contexto específico de interação, foram interpretados considerandose a sua articulação com as relações interpessoais desenvolvidas e com os circunscritores culturais presentes no contexto de uma unidade de internação. 
Ademais, a Oficina de Reflexão, como contexto mediador, favoreceu a interação entre as adolescentes e possibilitou a emergência de processos reflexivos que culminaram na ressignificação de algumas relações interpessoais no módulo feminino. De acordo com Zittoun (2009), os processos reflexivos facilitam a reorganização subjetiva, visto que colaboram para o desenvolvimento das percepções tanto de si como do contexto no qual o sujeito está inserido. Consoante Yokoy de Souza (2012), os processos reflexivos constituem uma característica da espécie humana que permite o planejamento e a transformação do futuro e de si. Assim, a nossa sugestão, após a análise dessa dimensão, é que sejam repensadas estratégias semióticas que impliquem espaços de comunicação e interação concretas no cotidiano das instituições privativas de liberdade. 


\title{
Capítulo VI:
}

\section{Considerações Finais}

\author{
"Quando é coisa boa, a gente não pode aparecer, mas quando é \\ coisa ruim, eles logo mostram a gente na TV. Vai entender esse \\ sistema..." (Maria da Penha, 17 anos). \\ "O que mais me incomoda na cultura machista é a forma como o \\ homem se acha superior à mulher." (Guacira,18 anos).
}

A construção de uma pesquisa de Mestrado não é um processo simples. Ao longo do caminho é necessário que sejam tomadas decisões nem sempre fáceis. Em um universo de possibilidades, escolhas precisam ser feitas e ideias precisam ser amadurecidas para que se faça jus à relevância do trabalho que se pretende desenvolver.

E assim, motivadas pelo interesse em investigar e compreender as interações cotidianas em uma unidade de Medida Socioeducativa de Internação - especificamente aquelas que refletem as desigualdades de gênero - demos vida a esse projeto. Entretanto, a proposta de um aprofundamento no conhecimento do atendimento socioeducativo, sob a perspectiva das adolescentes, não foi um tema de pesquisa inicialmente bem recebido por todos os/as educadores/as sociais. Isso foi percebido nas diversas dificuldades com as quais nos deparamos para a realização das atividades com as adolescentes, especialmente na unidade onde foram realizados os quatro primeiros encontros da Oficina de Reflexão. Nesse sentido, a continuidade da intervenção foi um dos maiores desafios enfrentados ao longo da pesquisa. Não saberíamos dizer, portanto, quem que foi responsável pela nossa permanência em campo. Mais justo seria atribuir o êxito do estudo a uma rede de colaboradores.

A possibilidade de um olhar retrospectivo sobre processo de composição da pesquisa nos permite (re)avaliar e (re)significar os diversos momentos de construção de 
conhecimento. As dificuldades pelas quais passamos para que pudéssemos concretizar os 10 encontros da Oficina de Reflexão não estão apenas relacionadas à discriminação que vivenciam as adolescentes que cometem atos infracionais, como imaginávamos no início da pesquisa. Mas, também, a fatores políticos, sócio-histórico-culturais e institucionais que permeiam o Sistema Socioeducativo do DF, e que influenciam fortemente as trajetórias de mudança das adolescentes durante a internação e o processo de reinserção social.

Portanto, adotar como perspectiva teórica apenas os estudos feministas não nos trouxe subsídios suficientes para analisar e interpretar as narrativas das adolescentes sobre o processo socioeducativo, visto que este é atravessado por distintas formas de poder. Desse modo, propusemos uma articulação entre os estudos de gênero e a Psicologia Sociocultural. Todavia, cabe ressaltar, o diálogo entre essas duas perspectivas não está consolidado, e a presente pesquisa pretende contribuir para tal.

Ademais, a filiação teórico-epistemológica assumida neste estudo, que reconhece a complexidade de fatores subjetivos e dialógicos que interagem na promoção de processos de desenvolvimento, nos mostrou que conhecer um pouco mais o contexto em que estavam inseridas as adolescentes participantes da pesquisa seria primordial para a análise e interpretação das formas de desenvolvimento engendradas naquele espaço. A construção de uma relação recíproca de respeito, carinho e confiança entre as pesquisadoras e as adolescentes também se mostrou fundamental para o êxito da intervenção. E a certeza de que suas concepções e posicionamentos, evidenciados na Oficina de Reflexão, não teriam influência na progressão das respectivas medidas socioeducativas contribuiu para que as adolescentes se sentissem ainda mais à vontade para expressar suas opiniões sobre aspectos da medida socioeducativa e do atendimento nas unidades de internação. Entretanto, é interessante ressaltar que em um contexto 
onde há privação da liberdade, o isolamento e as regras de convivência muitas vezes interferem na qualidade da interação entre os pares. Nesse sentido, foi preciso que, como pesquisadoras, estivéssemos constantemente atentas aos sinais não verbais partilhados nas interações ao longo dos encontros, a fim de evitar situações como a disputa da atenção das pesquisadoras pelas adolescentes e/ou de desentendimentos entre as próprias adolescentes.

Falar sobre a rotina das adolescentes na unidade de internação, ainda nos primeiros encontros, favoreceu a expressão das desigualdades de gênero que permeiam as normas, os significados e os posicionamentos institucionais. Consequentemente, o tema do (não) lugar institucional que ocupam as adolescentes em cumprimento de medida socioeducativa de internação, bem como as desigualdades de gênero que permeiam o cotidiano das relações sociais e das normas institucionais estabelecidas no contexto socioeducativo foi, aos poucos, marcando presença nas reflexões e discussões que realizamos nos encontros. Logo, tomar como ponto de partida as desigualdades de gênero presentes nas interações sociais cotidianas (na comunidade, em família, com os amigos, na instituição, etc.) para evocar narrativas e reflexões sobre o processo socioeducativo foi uma decisão compartilhada entre as pesquisadoras e as adolescentes participantes da pesquisa.

Cabe destaque ao fato de que, inicialmente, a pesquisa seria desenvolvida em dois momentos distintos, a saber: (1) a realização de um estudo-piloto, visando uma aproximação ao campo e às adolescentes que participariam da pesquisa; (2) o desenvolvimento de uma oficina pedagógica que teria como foco a discussão e a reflexão de questões relativas ao processo socioeducativo. Entretanto, ao analisarmos o trabalho desenvolvido ao longo de toda a intervenção - que inicialmente chamávamos de estudo piloto e estudo principal - percebemos haver um fio condutor que nos levou a 
compreender o processo como um todo. Nesse sentido, optamos por analisar esses dois momentos da Oficina de Reflexão como partes integrantes de um único processo.

Ao longo desse estudo procuramos contribuir com reflexões acerca do preconceito e da discriminação contra as adolescentes que cometem atos infracionais, sejam esses expressos no macrocontexto social ou no mesocontexto institucional. Dos encontros e das atividades desenvolvidas na Oficina de Reflexão emergiram várias informações relevantes para a compreensão dos processos de desenvolvimento subjetivo das adolescentes em contexto de privação de liberdade, e que necessitam ser consideradas nas políticas e programas que visem qualificar o atendimento socioeducativo. Convergindo com a perspectiva psicológica sociocultural que procura enfatizar o papel ativo do sujeito em seu desenvolvimento, as narrativas das adolescentes assinalaram que, ao contrário da mera reprodução de um discurso institucional, elas produzem novos significados a partir das (poucas) possibilidades concretas de interação e de trocas intersubjetivas. Isso porque, de acordo com a nossa compreensão, as adolescentes, mesmo diante de uma forte pressão social e institucional, procuram resistir aos mecanismos institucionais normatizadores, especialmente no que se refere à naturalização dos papéis de gênero e à estigmatização do/da adolescente que comete ato infracional.

A interpretação de suas narrativas apontou, sobretudo, a necessidade de mais oportunidades de interação das adolescentes com os diferentes atores sociais (educadores/as e colegas). Entretanto, não se trata apenas de mais interação, pois igualmente relevante se mostrou a qualidade dessas interações, visto que esses mesmos atores assumem importantes papéis no processo de ressignificação e de construção de novas trajetórias de vida, como exemplificado nas falas de Naomi e Maria da Penha, 
especialmente nas análises das dimensões Privação de Liberdade $\leftrightarrow$ Promoção de Desenvolvimento e Interação Social $\leftrightarrow$ Isolamento.

Todavia, é interessante chamar a atenção para o fato de que não são frequentes, para as adolescentes, oportunidades para a criação de um espaço de fala onde possam livremente expor suas dificuldades e suas vivências dentro do SSE. Nesse sentido, reproduzir situações que favorecem o isolamento no contexto institucional parece ser uma estratégia de regulação e controle da subjetividade, adotada de diferentes modos. Assim, a integração entre a Oficina de Reflexão e as atividades desenvolvidas nas aulas de artes possibilitou, ainda mais, a emergência de processos reflexivos e transformadores para as adolescentes. Ademais, a carência de momentos de interação entre elas, muitas vezes influenciou a qualidade das interrelações dentro do módulo feminino, resultando em desavenças que poderiam ser resolvidas a partir do diálogo e da (re)negociação de algumas normas de convivência, como foi possível perceber na análise do episódio “A maioria aqui se gosta, mas direto rola 'guerra'.”.

As informações da pesquisa permitiram, a partir da voz das adolescentes, identificar a existência de visões institucionais estereotipadas. Signos como a naturalização dos papéis de gênero e a desvalorização do feminino, sob essa perspectiva, além de contribuir para a manutenção das diferenças de poder entre homens e mulheres, as desqualificam como sujeitos, criando barreiras ainda mais severas para o seu desenvolvimento subjetivo. Isso nos leva a compreender que, muitas vezes, essas concepções são mais determinantes das atuações do sistema socioeducativo do que a própria conduta das adolescentes. Tudo isso aponta para a necessidade de se contribuir para a desconstrução da visão estereotipada sobre as adolescentes que cometem atos infracionais. 
Consoante a Resolução 119/2006 - CONANDA, a ação socioeducativa se dá mediante parâmetros que são subdivididos em eixos temáticos, dentre os quais um se refere à diversidade étnico-racial, de gênero e orientação sexual. Nesse sentido, devem constar do projeto político-pedagógico de todas as entidades e/ou programas que executam as medidas socioeducativas, ou se encarregam da internação provisória, propostas de execução de ações de promoção da igualdade e de combate à discriminação, ao preconceito e à desigualdade de gênero e racial, visando erradicar as injustiças e a exclusão social. Imperativo se faz, portanto, um olhar mais atento relação às desigualdades e ao preconceito no contexto socioeducativo.

Tomando essas informações como base, concluímos que a instituição socioeducativa infelizmente ainda tem se caracterizado como um contexto disciplinador e normatizador das subjetividades. Os valores e as normas institucionais profundamente arraigados - ainda são pautados em uma moral conservadora e ultrapassada, muitas vezes fundamentada na reprodução de valores sexistas que contribuem para a submissão da mulher nos diferentes contextos sociais.

Estudos adicionais mais aprofundados, sobre sistemas de crenças e valores sociais que contribuem para sustentar posicionamentos discriminatórios e de preconceito presentes nas instituições educacionais, de assistência e de cuidado, se mostram muito necessários. Da mesma forma, é importante o incremento de pesquisas de corte etnográfico que levem o pesquisador ao interior das instituições de internação e, desse modo, lhe permita um contato mais íntimo com o cotidiano das relações humanas nesse contexto. Por outro lado, reconhecemos como um elemento limitador desse estudo, as dificuldades encontradas para se apontar indicadores de desenvolvimento humano como efeito da mediação da MSE. Assim, ao lado de aspectos institucionais, esse resultado indica a necessidade de estudos futuros com 
desenhos metodológicos que possibilitem abordagens microanalíticas, mais propensas a captar a microgênese dos processos de desenvolvimento humano que ocorrem em um contexto tão peculiar quanto o que foi aqui investigado.

Face ao exposto, essa pesquisa apontou a necessidade de outras investigações que possam contribuir, também, para a construção de novas práticas pedagógicas no cotidiano das instituições socioeducativas. Tais práticas devem colaborar para a concretização de experiências que favoreçam os processos de reflexão e de ressignificação de crenças e valores, visando à construção de novos posicionamentos comprometidos com o respeito às diversidades. Como colocam Madureira \& Branco (2012), o preconceito e a discriminação não são objeto de estudo apenas da Psicologia, mas encontram-se na interface entre diversas áreas das ciências humanas. Sendo assim, diálogos interdisciplinares podem possibilitar uma compreensão mais ampla e efetiva do fenômeno. Nesse sentido, sugerimos que reflexões como as que trouxemos nesse estudo (bem como demais estudos sobre o processo socioeducativo) não fiquem restritos ao campo acadêmico, mas que possam tomar corpo junto às diversas instituições e/ou programas que participam da execução das medidas socioeducativas e da internação provisória. 


\section{Referências Bibliográficas}

Abramovay \& cols. (2010). Gangues, Gênero e Juventude: Donas de Rocha e Sujeitos Cabulosos. Brasília-DF: SDH/PR

Assis, S. G. \& Constantino, P. (2001). Filhas do mundo: infração juvenil feminina no Rio de Janeiro. Rio de Janeiro: Fundação Oswaldo Cruz.

Baratta, A. (1999). Paradigma do Gênero: da questão criminal à questão humana. In: Campo, Carmen (org.). Criminologia e Feminismo. Porto Alegre: Sulina.

Baratta, A. (2013). Criminologia crítica e crítica do Direito penal: introdução à sociologia do direito penal. Rio de Janeiro: Revan.

Barcinski, M. (2012). Mulheres no tráfico de drogas: a criminalidade como estratégia de saída da invisibilidade social feminina. Contextos Clínicos, 5(1). pp. 52-61. JanJun/2012.

Bastos, A. C.; Uriko, K, \& Valsiner, J. (orgs.) (2012). Cultural dynamics of women's lives.USA: IAP.

Bauer, W. M. \& Gaskell, G. (2002). Pesquisa qualitativa com texto, imagem e som: um manual prático. Petrópolis: Vozes.

Benjamin, Walter. (1994). O Narrador: considerações sobre a obra de Nikolai Leskov. In: Magia e técnica, arte e política: ensaios sobre a literatura e história da cultura (pp. 197221). São Paulo: Brasiliense.

Bisinoto, C. (Org.). (2014). Docência na socioeducação. Brasília: Universidade de Brasília, Campus Planaltina.

Branco, A. U. (2006). Crenças e práticas culturais: co-construção e ontogênese de valores sociais. Pro-posições, v.17. n. 2 (50) - maio/agosto.

Braconnier, A. \& Marcelli, D. (1998). As mil faces da adolescência. Lisboa: Climepsi.

BRASIL. (2011a). Atendimento socioeducativo ao adolescente em conflito com a lei. Brasília, DF.

BRASIL. (2011b). Mulheres Presas - Dados Gerais. Projeto Mulheres, Departamento Penitenciário Nacional.

BRASIL, Sistema Nacional de Atendimento Socioeducativo, Lei 12594, Institui o Sistema Nacional de Atendimento Socioeducativo (SINASE), regulamenta a execução das medidas socioeducativas destinadas a adolescente que pratique ato infracional. 
BRASIL, Sistema Nacional de Atendimento Socioeducativo. (2006). Resolução ${ }^{\circ} 119$, do Conselho Nacional dos Direitos da Criança e do Adolescente, 11 de dezembro de 2006. Dispõe sobre o Sistema Nacional de Atendimento Socioeducativo e dá outras providências.

Brito, E. Z. C. de (2007). Justiça e Gênero: uma história da justiça de menores em Brasília (1960 - 1990). Brasília: UnB.

Bruner, J. (1991). The narrative construction of reality. Critical Inquiry, vol 18, n. 1, pp. 121. Chicago: The University of Chicago Press.

Camargo, C. K., Marinho, F. C., Santos, S. L., Gutierres, S. M. \& Galinkin, A. L. (2013). $\mathrm{O}$ perfil da adolescente em conflito com a lei no Distrito Federal à luz das perspectivas teóricas tradicionais e feministas. Anais do Congresso Interamericano de Psicologia, 34, 364.

Castro, L. R. de \& Besset; V. L. (Orgs.). (2008). Pesquisa-intervenção na infância e juventude. Rio de Janeiro: NAU.

Carvalho, I. C. M. (2003). Biografia, identidade e narrativa: elementos para uma análise hermenêutica. Horizontes Antropológicos, Porto Alegre, ano 9, n. 19, p.283-302, julho de 2003.

CONSELHO FEDERAL DE PSICOLOGIA - CFP. (2006 b). Direitos Humanos: um retrato das unidades de internação de adolescentes em conflito com a lei. Brasília: Conselho Federal de Psicologia.

CONSELHO NACIONAL DE DEFESA DOS DIREITOS DA CRIANÇA E DO ADOLESCENTE - CONANDA. Resolução 119/2006. Sistema Nacional de Atendimento Socioeducativo - SINASE. Brasília: CONANDA.

Costa, A. C. G. da (2001). Aventura pedagógica. Belo Horizonte: Modus Faciendi.

Costa, A. C. G. da (2001). Educação e Vida. Belo Horizonte: Modus Faciendi.

Correia, M. F. B. (2003). A constituição social da mente: (re) descobrindo Jerome Bruner e construção de significados. Estudos de Psicologia, 8(3), pp. 505-513.

Del Priore, M. (org.). (2012). História das mulheres no Brasil. São Paulo: Contexto

Estatuto da Criança e do Adolescente. Lei $\mathrm{n}^{\mathrm{o}}$ 8.069/1990. Publicada no DOU de 16.07.90, seção1. 2002. Ministério da Justiça.

Espinoza, O. (2002). A Prisão Feminina desde um Olhar da Criminologia Feminista. Revista Transdisciplinar de Ciências Penitenciárias. Vol. 1, n. 1. Jan - Dez/2002. pp. 35-39.

Fávero, M. H. (2010). Psicologia do Gênero. Psicobiografia, Sociocultura e Transformações. Curitiba: Editora da Universidade Federal do Paraná. 
Faccio, A. \& Camacho, R. (1995). Em busca das mulheres perdidas - ou uma aproximação - crítica à criminologia. In: Mulheres: vigiadas e castigadas (pp. 26-64). São Paulo: CLADEM Brasil.

Flick, U. (2004). Uma introdução à pesquisa qualitativa. Porto Alegre: Bookman.

Leite, V. (2013). Sexualidade adolescente como direito? A visão de formuladores de políticas públicas.Rio de Janeiro: EdUERJ

Lightfoot, C. (1997).The culture of adolescente risk-taking. New York: The Gilford Press.

Lopes de Oliveira, M. C. S. (2003). Do sujeito da representação ao sujeito dialógico. Revista do departamento de psicologia da UFF, 15(1), pp. 32-52.

Lopes de Oliveira, M. C. S. (2006). Identidade, Narrativa e Desenvolvimento na Adolescência: Uma Revisão Crítica.Psicologia em Estudo, Maringá, v. 11, n. 2, pp. 427-436.

Lopes de Oliveira, M. C. S. (2014). Desenvolvimento do self e processos de hiperindividualização: interrogações à psicologia dialógica. Manuscrito em elaboração.

Lopes de Oliveira, M. C. S. \& Madureira, A. F. do A. (2014) Gênero e psicologia do desenvolvimento: quando a ciência é utilizada como força normatizadora das identidades de gênero. Estudos Feministas - julho/dezembro de 2014.

Lopes de Oliveira, M. C. S. \& Vieira, A. O. M. (2006). Narrativas sobre a privação de liberdade e o desenvolvimento do self adolescente.Educação e Pesquisa, v. 32, n.1, pp. 67-83.

Louro, G. L. (1997). Gênero, sexualidade e educação. Petrópolis, RJ: Vozes.

Louro, G. L. (org). (2010). O corpo educado: pedagogias da sexualidade. Belo Horizonte: Autêntica Editora.

Louro, G. L.; Felipe, J. \& Goellner, S. (orgs). (2013). Corpo, gênero e sexualidade; um debate contemporâneo na educação. Petrópolis, RJ: Vozes.

Madeira, F. R. (org.). (1997). Quem mandou nascer mulher? Estudos sobre crianças e adolescentes pobres no Brasil.Rio de Janeiro: Rosa dos Tempos.

Madureira, A. F. do Amaral (2007a). Gênero, sexualidade e diversidade na escola: a construção de uma cultura democrática. Tese de Doutorado; Universidade de Brasília, Brasília, DF.

Madureira, A. F. A. \& Branco, A. U. (2001). A pesquisa qualitativa em psicologia do desenvolvimento: questões epistemológicas e implicações metodológicas. Temas em Psicologia, 9 (1), pp. 63-75. 
Madureira, A. F. A. \& Branco, A. U. (2005). Construindo com o outro: uma perspectiva sociocultural construtivista do desenvolvimento humano. In: Dessen \& Costa Junior (orgs.). A ciência do desenvolvimento humano: tendências atuais e perspectivas futuras (pp. 90-109). Porto alegre: Artes Médicas.

Madureira, A. F. A \& Branco, A. U. (2012). As raízes histórico-culturais e afetivas do preconceito e a construção de uma cultura democrática na escola. In: Branco \& Lopes de Oliveira (orgs.). Diversidade e cultura da paz na escola: contribuições da perspectiva sociocultural (pp. 125-155). Porto alegre: Mediação.

Madureira, A. F. A \& Branco, A. U. (2014). Gênero, sexualidade e desenvolvimento humano: construindo uma cultura democrática na escola. In: Dessen e Maciel. (orgs.) A ciência do desenvolvimento humano (pp. 145-171). Curitiba: Juruá.

McAdamas, D. (2001). The psychology of life stories. Review of General Psichology, vol. 5 , n.2, pp. 100-122.

Mendes, S. R. (2014). Criminologia Feminista: novos paradigmas. Saraiva: São Paulo.

Menezes, J. A., Arcoverde, L. R. \& Libardi, S. S. (2008). A pesquisa-intervenção com adolescentes: oficina como contexto narrativo sobre igualdade e diferença. In: Castro \& Besset (orgs.). Pesquisa-intervenção na infância e juventude (pp. 225-223). Rio de Janeiro: NAU.

Minayo, M. C. de S. (org.) (2009). Pesquisa Social: Teoria, método e criatividade. Petrópolis, RJ: Vozes.

Paiva, I. L. de, Souza, C. \& Rodrigues, D. B. (orgs.). (2014). Justiça juvenil: teoria e prática no sistema socioeducativo. Natal: EDUFRN.

Pinsky, C. B. \& Pedro, J. M. (orgs.). (2013). Nova história das mulheres no Brasil. São Paulo: Contexto.

Prado, M. A. M., Oliveira, M. M. de \& Oliveira Jr, O. (2008). A pesquisa-intervenção e a emergência dos atores sociais: considerações a partir da experiência de jovens rurais. In: Castro \& Besset (orgs.). Pesquisa-intervenção na infância e juventude (pp. 179-204) Rio de Janeiro: NAU.

Ramos, L. S.(2010). Como as meninas são (não) vistas pelo sistema de medidas socioeducativas do Distrito Federal. In Brasil. Situação dos Adolescentes privados de Liberdade. Centro de Defesa da criança e do Adolescente. Brasília, DF.

Rebouças, F. P. (2015). O Processo de Responsabilização Socioeducativa: Da Medida à Responsabilidade. Dissertação de Mestrado ainda não publicada. Universidade de Brasília, Brasília - DF.

Rego, T. C. R. (2000). A origem da singularidade humana na visão dos educadores. In Cadernos CEDES, n. 35. Implicações pedagógicas do modelo histórico cultural. Campinas: CEDES. 
Santos, J. L. dos. (2006). O que é Cultura. Coleção Primeiros Passos, n. 110. São Paulo: Brasiliense.

Santos, J. F. dos (org.). (2007). As cem melhores crônicas brasileiras. Rio de Janeiro: Objetiva.

Sarbin, T. R. (1986). Narrative psychology: the storied nature of human conduct. New York: Praeger.

Sato, L. (2008). Pesquisar e intervir: encontrando o caminho do meio. In: Castro \& Besset (orgs.). Pesquisa-intervenção na infância e juventude (pp. 171-178) Rio de Janeiro: NAU.

SECTRETARIA DE DIREITOS HUMANOS DA PRESIDÊNCIA DA REPÚBLICA e AGÊNCIA DE NOTÍCIAS DOS DIREITOS DA INFÂNCIA - DEDH e ANDI. (2012). Adolescentes em conflito com a lei: Guia de referência para a cobertura jornalística. Brasília: SEDH e ANDI.

SECRETARIA DE ESTADO DA MULHER/DF (2013). RECOMENDAÇÃO No 2/2013-CEDF.

Senna Pires, S. F. \& Branco, A. U. (2008). Cultura, Self e Autonomia: Bases para o protagonismo infantil. Psicologia: Teoria e Pesquisa. Out - Dez/2008, Vol. 24 n. 4. pp. 415-421.

Silva, I. R. \& Maciel, D. A. (2014). A escola como contexto de desenvolvimento: contribuições da psicologia escolar educacional. In: Dessen \& Maciel. (orgs.) A ciência do desenvolvimento humano (pp. 267-298). Curitiba: Juruá.

Scott, J. W. (1995). Gênero: uma categoria útil de análise histórica. Educação \& Realidade. Porto Alegre, vol.20, n², julho/dezembro de 1995, pp. 71-99.

Silvério, A. C. da S. (2008). As adolescentes em cumprimento de medida socioeducativa no DF: onde fica o gênero. Monografia de conclusão de curso. SER- IH. Brasília: UnB.

Toledo, D. C. (2014) Performance de gênero não normativa na adolescência: contribuições da teoria do self dialógico. Dissertação de Mestrado; Universidade de Brasília, Brasília, DF.

Tomio, N. A. O. \& Facci, M. G. D. (2009). Adolescência: uma análise a partir da Psicologia Sócio-Histórica. Revista Teoria e Prática da Educação, v.12, n.1, pp. 89-99.

Valsiner, J. (1994). Bidirectional cultural transmission and constructive sociogenesis. In: Graaf \& Maier (orgs.), Sociogenesis reexamined (pp. 47-70). New York: Springer.

Valsiner, J. (2012). Fundamentos de uma psicologia cultural: mundos da mente, mundos da vida. Porto Alegre: Artmed. 
Valsiner, J., Branco, A. U. \& Dantas, C. (1997). Co-construction of human development. In: Shantz \& Hartup (orgs.). Conflict in child and adolescente development (pp. 15-35). Cambridge, MA: Cambridge University Press.

Vieira, A. O. M. (2004). Adolescentes em privação de liberdade: diálogos e narrativas dos sujeitos em situação de construção de texto. Dissertação de Mestrado; Universidade de Brasília, Brasília, DF.

Vieira, A. M. \& Lopes de Oliveira, M. C. (2013). Promoção do desenvolvimento subjetivo do adolescente por meio de intervenção psicopedagógica no contexto socioeducativo. In: Lago, Mozzer \& Santibanez. Adolescência: temores e saberes de uma sociedade em conflito (pp. 161-191). Goiânia: Cânone Editorial

Vigotski, L.S. (2000). O manuscrito de 1929. Educação \& Sociedade, 71, pp. 21-44.

Vigotski, L.S. (2011). A formação social da mente. São Paulo: Martins Fontes.

Vigotski, L.S. (2010). Psicologia Pedagógica. São Paulo: Martins Fontes

Vigotski, L.S. (2013). Pensamento e Linguagem. São Paulo: Martins Fontes.

Weeks, J. (2010). O corpo e a sexualidade. In: Louro (org). O corpo educado: pedagogias da sexualidade (pp. 36-82). Belo Horizonte: Autêntica Editora.

Yokoy de Souza, T. (2007). Um estudo dialógico sobre institucionalização e subjetivação de adolescentes em uma casa de semiliberdade. Dissertação de Mestrado; Universidade de Brasília, Brasília, DF.

Yokoy de Souza, T. (2012). Processos de desenvolvimento de educadores sociais do sistema de medidas socioeducativas: indicadores de formação. Tese de Doutorado; Universidade de Brasília, Brasília, DF.

Yokoy de Souza, T., Branco, A. U. \& Lopes de Oliveira, M. C. S. (2008). Pesquisa Qualitativa e Desenvolvimento Humano: Aspectos Históricos e Tendências Atuais. Fractal: Revista de Psicologia, 20 (2), pp. 357-376.

Yokoy de Souza, T. \& Lopes de Oliveira, M. C. S. (2008). Trajetórias de Desenvolvimento e Contextos de Subjetivação e Institucionalização de Adolescentes em Cumprimento de medidas Socioeducativas. Pesquisas e Práticas Psicossociais 3 (1), São João Del-Rei.

Yokoy de Souza, T. \& Lopes de Oliveira, M. C. S. (2012). O contexto das medidas socioeducativas: promoção da paz ou valores da cadeia? In: Branco \& Lopes de Oliveira (orgs.). Diversidade e cultura da paz na escola: contribuições da perspectiva sociocultural (pp. 291-309). Porto alegre: Mediação.

Zanella, A. V. (2004). Atividade, significação e constituição do sujeito: considerações à luz da Psicologia histórico-cultural. Psicologia em Estudo, Maringá, v. 9, n. 1, pp. 127-135. 
Zittoun, T. (2009). Dynamic Process Methodology in the Social and developmental Sciences, chapter 18, pp. 405-429.

Zittoun, T. (2012). On the Emergence of the Subject. Integr Psych Behav. 46, pp. 259273.

Zittoun, T. (2005). Processes of Inferiority. In: Simão \& Valsiner (orgs.). Otherness in question: labyrints of the self. Greenwich, CT: Information Age. 
Apêndice 1- Autorização judicial para a realização da pesquisa com adolescentes em cumprimento de MSE de Internação no DF

\section{TJDFT Poder Judiciário da Uniăo}

TRIBUNAL DE JUSTIÇA DO DISTRITO FEDERAL E DOS TERRITÓRIOS

Vara de Execução de Medidas Socioeducativas do Distrito Federal

SGAN 909, Módulos D/E | CEP 70790-090-Brasilia-DF

(61) 31033365 | 31030307 | vemse@tjdft.jus.br

\section{AUTORIZAÇÃO}

Autorizo DANIELA LEMOS PANTOJA COELHO DE OLIVEIRA COSTA, aluna do Mestrado do Programa de Pós-Graduação em Processo de Desenvolvimento Humano e Saúde do Instituto de Psicologia da UnB, a realizar, na Unidade de Internação do Recanto das Emas (UNIRE) ou na Unidade de Santa Maria (UISM), a pesquisa Oficinas de gênero: uma metodologia para a reflexão sobre o feminino no contexto do atendimento socioeducativo.

A pesquisa envolve a realização de oficinas pedagógicas que têm como objetivo discutir e aprofundar temas relativos à constituição de gênero feminino no contexto do cumprimento da medida socioeducativa de internação, bem como propor uma metodologia que favoreça a discussão de questões relativas à subjetividade e identidade de gênero em escolas do sistema socioeducativo. Para a pesquisa, pretende-se trabalhar com 8 (oito) adolescentes do sexo feminino, durante 10 (dez) semanas, com previsão de início em abril e término em julho de 2014. Os dias e horários das visitas deverão ser acordados previamente com a Direção da Unidade.

Ressalvo, no entanto, que não está permitido o registro de imagens ou vídeos das adolescentes, estando autorizado o registro em áudio, se necessário. Ainda, deve-se respeitar sempre a voluntariedade das socioeducandas em participar das pesquisas, bem como o disposto no art. 17 do Estatuto da Criança e do Adolescente, que dispõe sobre a preservação da imagem, da identidade, da autonomia, dos valores, ideias e crenças, dos espaços e objetos pessoais de crianças e adolescentes, e no art. 143 do referido diploma legal, que dispõe sobre o sigilo na divulgação de atos judiciais, policiais e administrativos que digam respeito a crianças e adolescentes a que se atribua a autoria de ato infracional,

Durante as atividades, a pesquisadora será auxiliada por Fernanda Pinheiro Rebouças, Raissa Costa Faria de Farias Seabra e Carolina Knihs de Camargo.

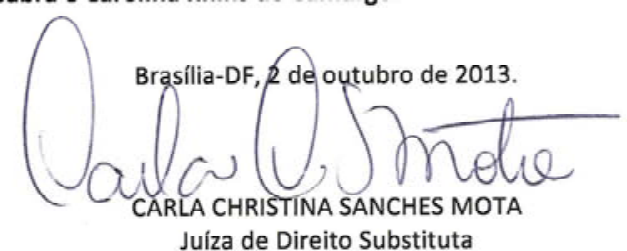

Juíza de Direito Substituta 
O/A Sr./Sra.

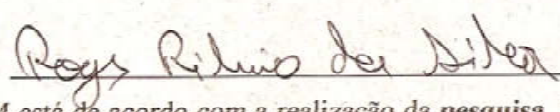
da SECRIA-DF/UISM está de acordo com a realização da pesquisa "OFICINAS DE GÊNERO: UMA METODOLOGIA PARA A REFLEXÃO SOBRE O FEMININO NO CONTEXTO DO ATENDIMENTO SOCIOEDUCATIVO", de responsabilidade da pesquisadora DANIELA LEMOS PANTOJA COELHO DE OLIVEIRA COSTA, RG 1404775 - SSP-DF, matrícula/UnB 13/0003857, aluna de MESTRADO no Instituto de Psicologia da Universidade de Brasilia, realizado sob orientação da Prof ${ }^{1}$ Dra Maria Cláudia Santos Lopes de Oliveira, após revisão e aprovação pelo Comitê de Ética em Pesquisa do Instituto de Ciências Humanas da Universidade de Brasília - CEP/IH.

O estudo envolve a realização de Oficinas Pedagógicas - que abordarão o tema Gênero, com 8 (oito) adolescentes do sexo feminino, na UISM - Unidade de Internação de Santa Maria. A pesquisa tem previsão de início no primeiro semestre de 2014, podendo ser estendida até o final do mesmo ano, caso necessário.

$$
\text { Eu, Rays Rilui do Dilled. }
$$

do/a SECRIA-DF/UISM declaro conhecer e cumprir as Resoluções Éticas Brasileiras, em especial a Resolução CNS 196/96. Esta instituição está ciente de suas coresponsabilidades como instituição co-participante do presente projeto de pesquisa, e de seu compromisso no resguardo da segurança e bem-estar dos sujeitos de pesquisa nela recrutados, dispondo de infra-estrutura necessária para a garantia de tal segurança e bem-estar.

Brasilia, 19 de Maio de 2014

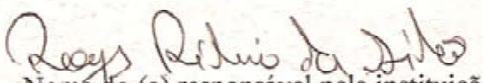

Nomedo (a) responsável pela instituição

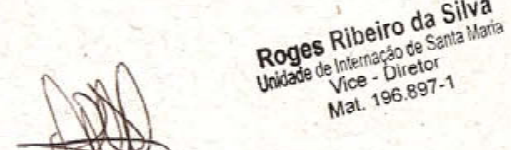

Assinfatura e carimbo do (a) responsável pela instituição 


\section{Apêndice 3 - Termo de Assentimento}

\section{Termo de Assentimento}

Você está sendo convidada a participar da pesquisa "OFICINAS DE GÊNERO: UMA METODOLOGIA PARA A REFLEXÃO SOBRE O FEMININO NO CONTEXTO DO ATENDIMENTO SOCIOEDUCATIVO", de responsabilidade de Daniela Lemos Pantoja Coelho de Oliveira Costa, mestranda do Programa de Pós-graduação em Processos de Desenvolvimento Humano e Saúde, do Instituto de Psicologia da Universidade de Brasília. O objetivo desta pesquisa é investigar e compreender questões relativas ao tema de gênero que se expressam na infração feminina e no atendimento socioeducativo às adolescentes autoras de ato infracional.

Ao assinar este Termo de Assentimento, você manifesta seu interesse voluntário, ou seja, por livre escolha, e disponibilidade de cooperar com a pesquisa, sabendo que não receberá qualquer remuneração para isso. Antes disso, é importante que você saiba que tem o direito de receber todos os esclarecimentos necessários à compreensão da pesquisa, antes, durante e após sua finalização. Assegurolhe que o seu nome não será divulgado em qualquer contexto. Será mantido o mais rigoroso sigilo mediante a omissão total de informações que permitam identificá-la. Os dados provenientes de sua participação na pesquisa, tais como questionários, entrevistas e fitas de gravação, ficarão sob a guarda da pesquisadora responsável pela pesquisa.

A coleta de dados será realizada por meio de sessões de discussão acerca dos temas que norteiam a pesquisa e de gravações de áudio. É para estes procedimentos que você está sendo convidado a participar. Sua participação na pesquisa não implica em nenhum risco.

Espera-se que os resultados desta pesquisa possam colaborar para a compreensão das adolescentes no contexto da prática infracional; para melhorar o atendimento às necessidades das adolescentes que cumprem medidas socioeducativas; para um maior comprometimento da escola, em geral, e das que funcionam dentro das unidades de internação, bem como para favorecer auto-imagens mais positivas das adolescentes autoras de ato infracional, que possam contribuir para outras trajetórias de desenvolvimento descomprometidas com a infração.

Ainda que assine este Termo de Assentimento, você é livre para, a qualquer momento, recusar-se a participar, retirar seu consentimento ou interromper sua participação, o que não acarretará qualquer penalidade ou perda de benefícios relacionados à medida socioeducativa.

Se você tiver qualquer dúvida em relação à pesquisa, pode me contatar através dos e-mails: danim23@uol.com.br, daniela.danim23@gmail.com, ou do telefone (61) 3107-6923.

A equipe de pesquisa garante que os resultados do estudo serão devolvidos aos participantes por meio de encontros na instituição,podendo ser publicados posteriormente na comunidade científica. 
Este projeto foi revisado e aprovado pelo Comitê de Ética em Pesquisa do Instituto de Ciências Humanas da Universidade de Brasília - CEP/IH. As informações com relação à assinatura do Termo de Assentimento ou os direitos do sujeito da pesquisa podem ser obtidos através do e-mail do CEP/IH cep_ih@unb.br.

Este documento foi elaborado em duas vias, uma ficará com a pesquisadora responsável pela pesquisa e a outra com a Gerência Socioeducativa desta Unidade de Internação.

Assinatura da participante:

Assinatura da pesquisadora:

Brasília, de de 2014 
Apêndice 4 - Atividades desenvolvidas pelas adolescentes nas aulas de Arte

"Desconstruindo estereótipos de gênero através de máscaras"

Autoria: Judith

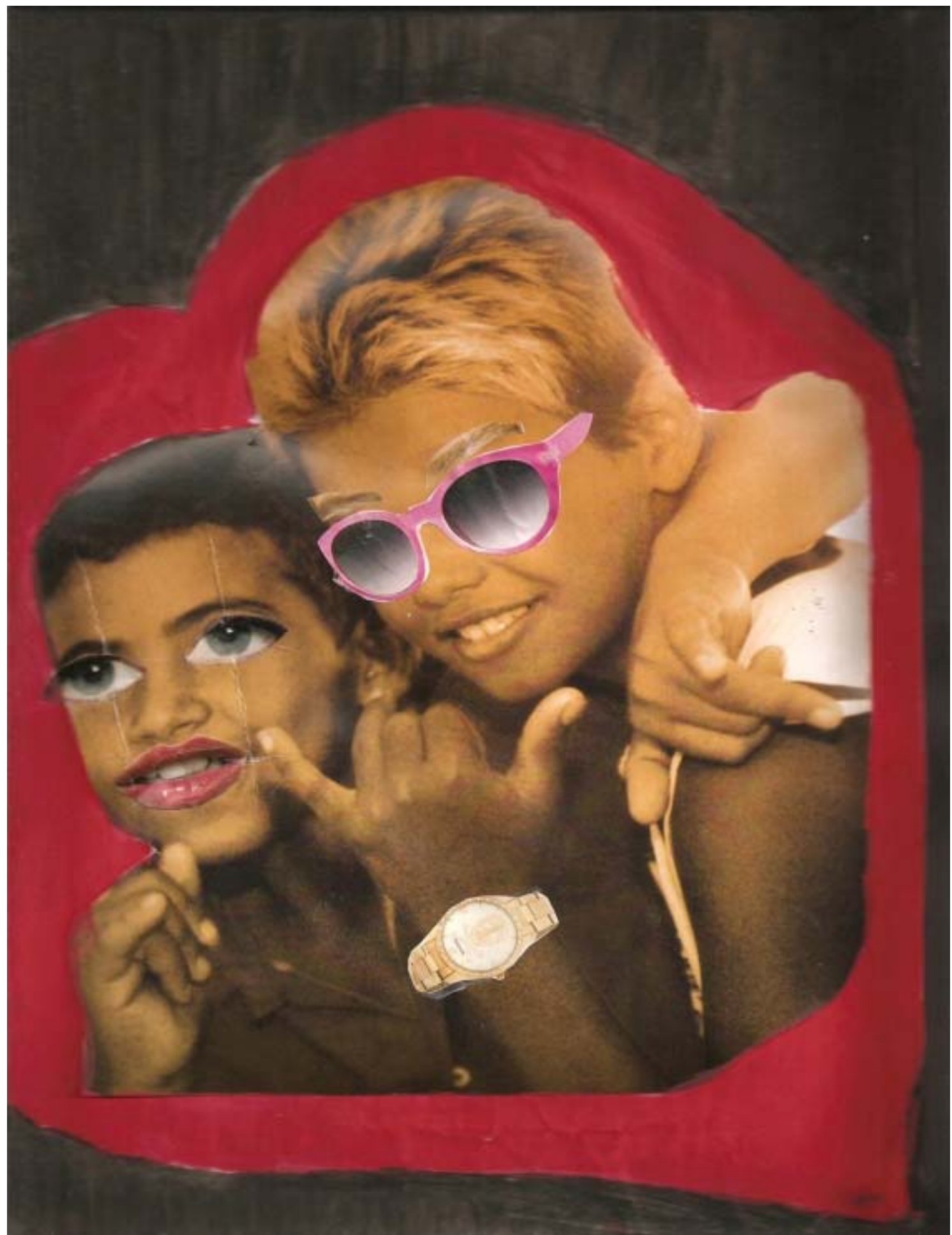


Autoria: Maria da Penha

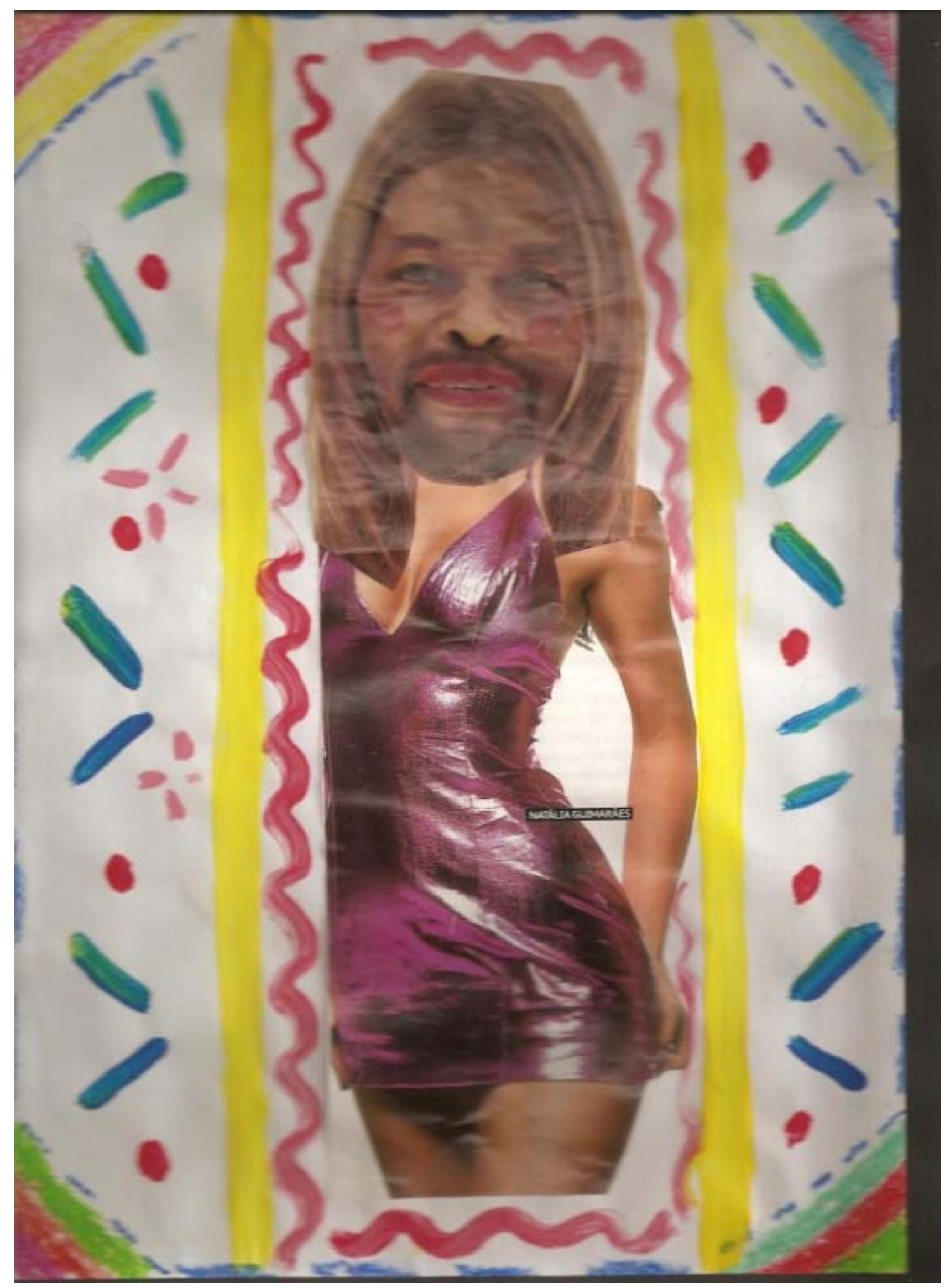


Autoria: Guacira

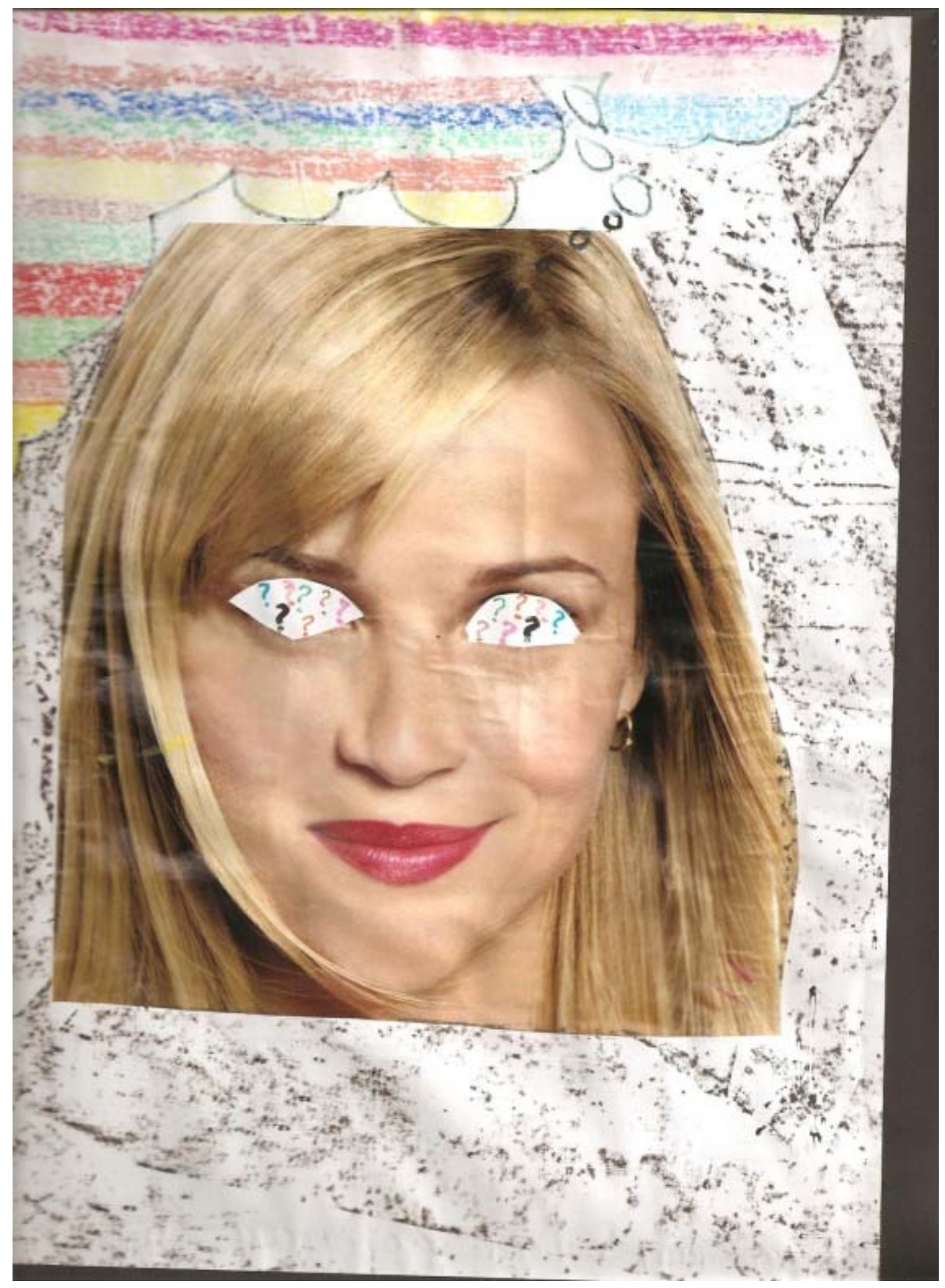


Autoria: Guacira

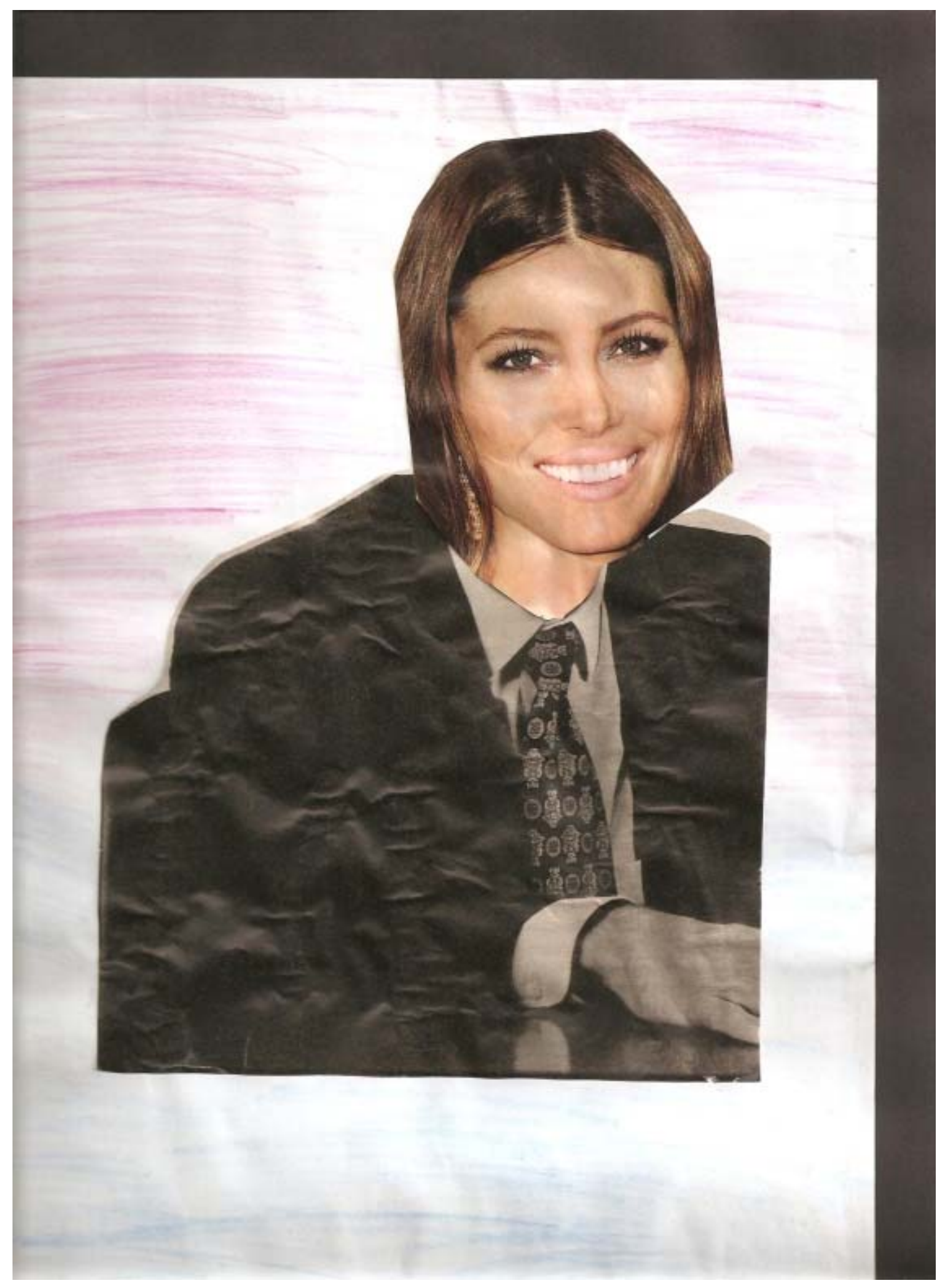


Autoria: Maria da Penha

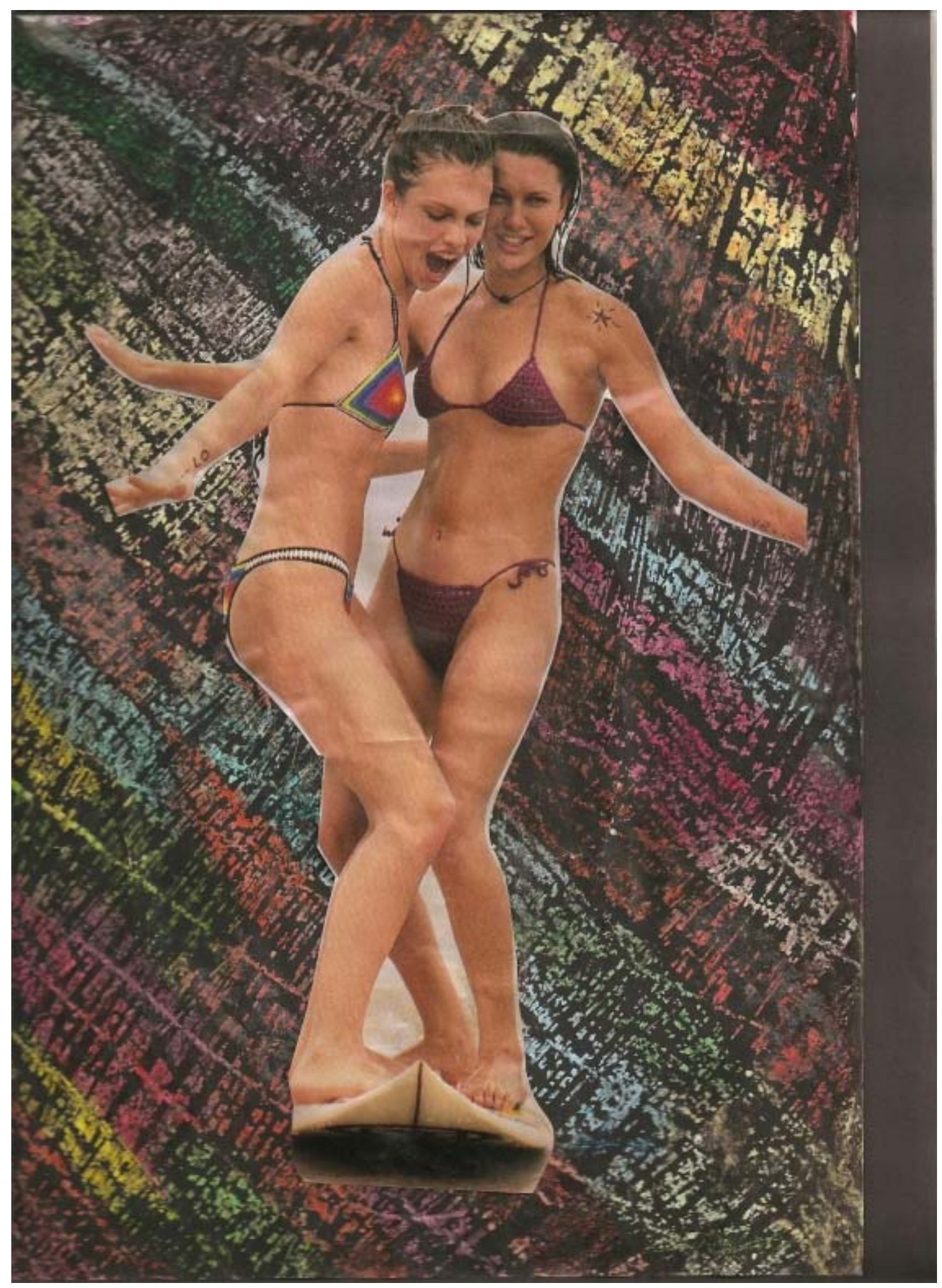


Autoria: Simone

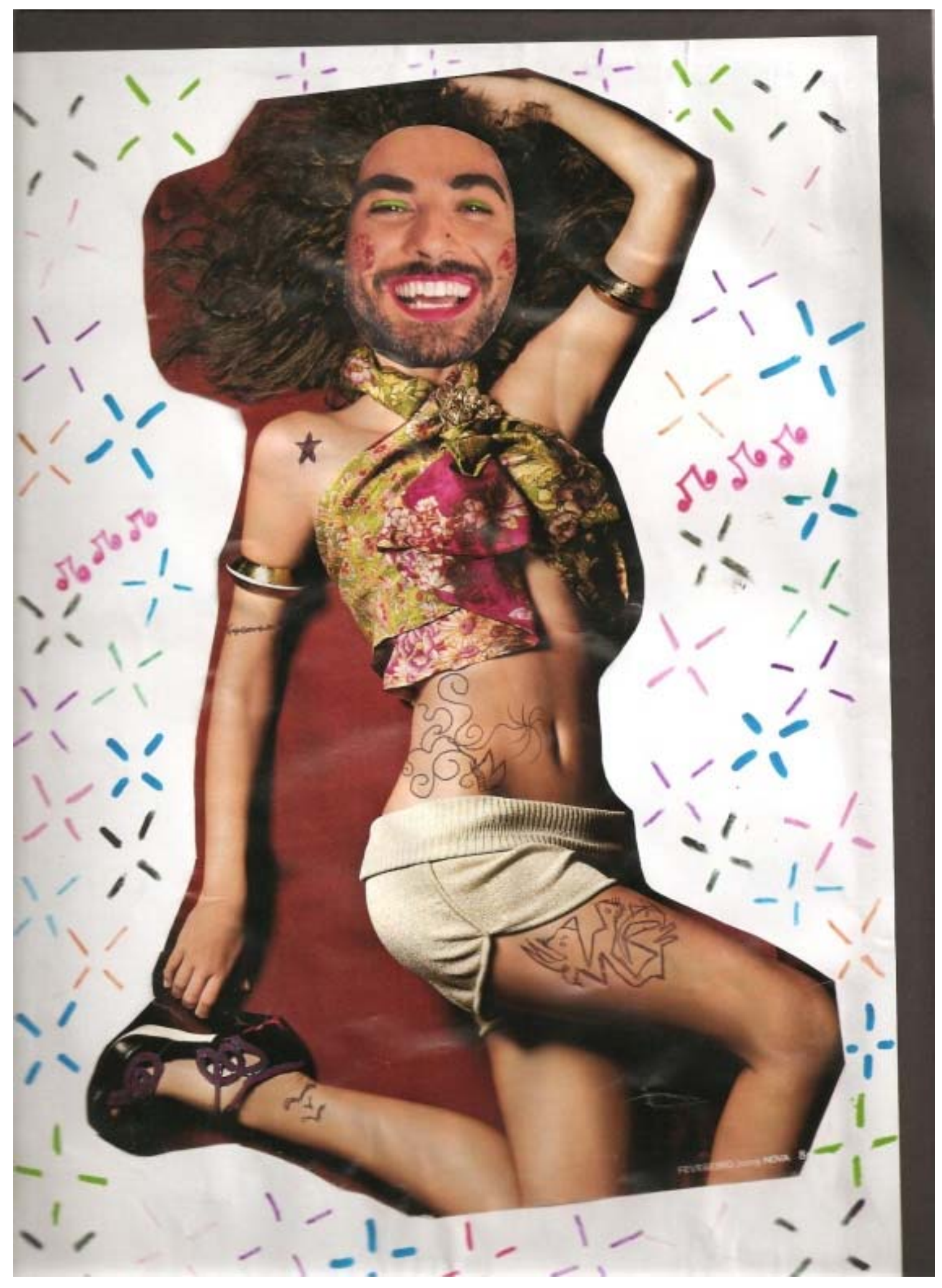


Apêndice 5 - Músicas utilizadas em atividades do encontro $n^{\circ} 6$

\section{Tem Pouca Diferenca}

\section{Gal Costa}

Que diferença da mulher o homem tem?

Espera aí que eu vou dizer, meu bem

É que o homem tem cabelo no peito

Tem o queixo cabeludo

E a mulher não tem

No paraíso um dia de manhã

Adão comeu maçã, Eva também comeu

Então ficou Adão sem nada, Eva sem nada

Se Adão deu mancada, Eva também deu

Mulher tem duas pernas, tem dois braços, duas coxas

Um nariz e uma boca e tem muita inteligência

O bicho homem também tem do mesmo jeito

Se for reparar direito tem pouquinha diferença.

\section{Masculino e Feminino}

\section{Pepeu Gomes}

Ôu! Ôu!

Ser um homem feminino

Não fere o meu lado masculino

Se Deus é menina e menino

Sou Masculino e Feminino...

Olhei tudo que aprendi

E um belo dia eu vi...

Que ser um homem feminino

Não fere o meu lado masculino

Se Deus é menina e menino

Sou Masculino e Feminino...

Olhei tudo que aprendi

E um belo dia eu vi

Uh! Uh! Uh! Uh...

E vem de lá!

O meu sentimento de ser 
E vem de lá!

O meu sentimento de ser

Meu coração!

Mensageiro vem me dizer

Meu coração!

Mensageiro vem me dizer...

Salve, salve a alegria

A pureza e a fantasia

Salve, salve a alegria

A pureza e a fantasia..

Olhei tudo que aprendi

E um belo dia eu vi

Uh! Uh! Uh! Uh...

Que ser um homem feminino

Não fere o meu lado masculino

Se Deus é menina e menino

Sou Masculino e Feminino...

Vou assim todo o tempo

Vivendo e aprendendo

Ôu!...

E vem de lá!

O meu sentimento de ser

E vem de lá!

o meu sentimento de ser

Meu coração!

Mensageiro vem me dizer

Meu coração!

Mensageiro vem me dizer

Ôu! Ôu! Uh!...

\section{$\underline{\text { Lavagem Cerebral }}$}

\section{Gabriel O Pensador}

Racismo preconceito e discriminação em geral

É uma burrice coletiva sem explicação

Afinal que justificativa você me dá para um povo que precisa de união

Mas demonstra claramente

Infelizmente

Preconceitos mil

De naturezas diferentes

Mostrando que essa gente 
Essa gente do Brasil é muito burra

E não enxerga um palmo à sua frente

Porque se fosse inteligente esse povo já teria agido de forma mais consciente

Eliminando da mente todo o preconceito

E não agindo com a burrice estampada no peito

A "elite" que devia dar um bom exemplo

É a primeira a demonstrar esse tipo de sentimento

Num complexo de superioridade infantil

Ou justificando um sistema de relação servil

E o povão vai como um bundão na onda do racismo e da discriminação

Não tem a união e não vê a solução da questão

Que por incrível que pareça está em nossas mãos

Só precisamos de uma reformulação geral

Uma espécie de lavagem cerebral

Não seja um imbecil

Não seja um ignorante

Não se importe com a origem ou a cor do seu semelhante

O quê que importa se ele é nordestino e você não?

O quê que importa se ele é preto e você é branco?

Aliás branco no Brasil é difícil, porque no Brasil somos todos mestiços

Se você discorda então olhe pra trás

Olhe a nossa história

Os nossos ancestrais

O Brasil colonial não era igual a Portugal

A raiz do meu país era multirracial

Tinha índio, branco, amarelo, preto

Nascemos da mistura então porque o preconceito?

Barrigas cresceram

O tempo passou...

Nasceram os brasileiros cada um com a sua cor

Uns com a pele clara outros mais escura

Mas todos viemos da mesma mistura

Então presta atenção nessa sua babaquice

Pois como eu já disse racismo é burrice

Dê a ignorância um ponto final:

Faça uma lavagem cerebral

Negro e nordestino constroem seu chão

Trabalhador da construção civil conhecido como peão

No Brasil o mesmo negro que constrói o seu apartamento ou que lava o chão de uma delegacia

É revistado e humilhado por um guarda nojento que ainda recebe o salário e o pão de cada dia graças ao negro, ao nordestino e a todos nós

Pagamos homens que pensam que ser humilhado não dói

O preconceito é uma coisa sem sentido

Tire a burrice do peito e me dê ouvidos

Me responda se você discriminaria

Um sujeito com a cara do PC Farias

Não, você não faria isso não... 
Você aprendeu que o preto é ladrão

Muitos negros roubam mas muitos são roubados

E cuidado com esse branco aí parado do seu lado

Porque se ele passa fome

Sabe como é:

Ele rouba e mata um homem

Seja você ou seja o Pelé

Você e o Pelé morreriam igual

Então que morra o preconceito e viva a união racial

Quero ver essa musica você aprender e fazer

A lavagem cerebral

O racismo é burrice mas o mais burro não é o racista

É o que pensa que o racismo não existe

$O$ pior cego é o que não quer ver

E o racismo está dentro de você

Porque o racista na verdade é um tremendo babaca

Que assimila os preconceitos porque tem cabeça fraca

E desde sempre não para pra pensar

Nos conceitos que a sociedade insiste em lhe ensinar

E de pai pra filho o racismo passa

Em forma de piadas que teriam bem mais graça

Se não fossem o retrato da nossa ignorância

Transmitindo a discriminação desde a infância

E o que as crianças aprendem brincando

É nada mais nada menos do que a estupidez se propagando

Qualquer tipo de racismo não se justifica

Ninguém explica

Precisamos da lavagem cerebral pra acabar com esse lixo que é uma herança cultural

Todo mundo é racista mas não sabe a razão

Então eu digo meu irmão

Seja do povão ou da "elite"

Não participe

Pois como eu já disse racismo é burrice

Como eu já disse racismo é burrice

E se você é mais um burro

Não me leve a mal

É hora de fazer uma lavagem cerebral

Mas isso é compromisso seu

Eu nem vou me meter

Quem vai lavar a sua mente não sou eu

É você 
Apêndice 6- Imagem "Biscoito Sexual"

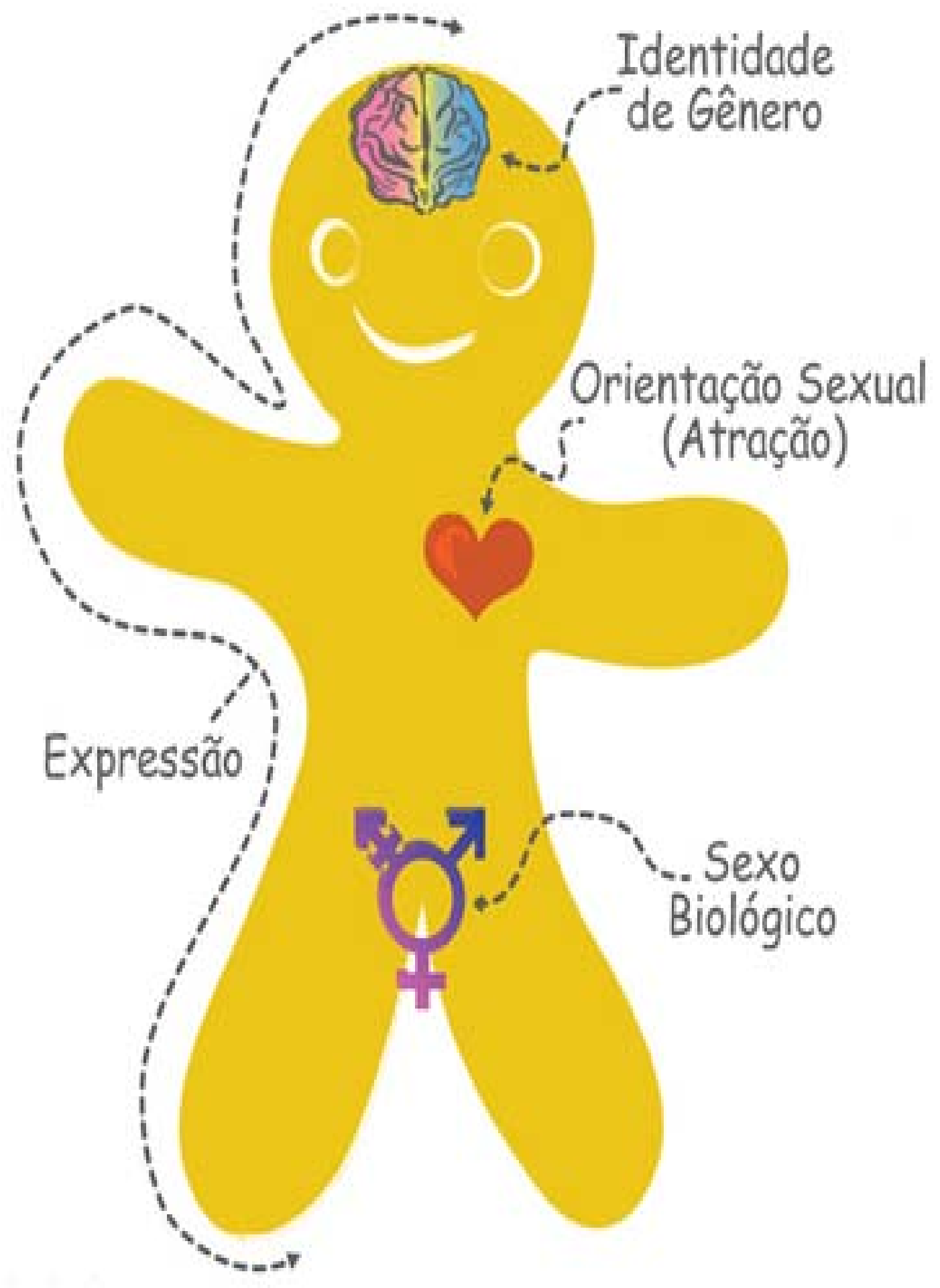


Apêndice 7- Mural dos Desejos

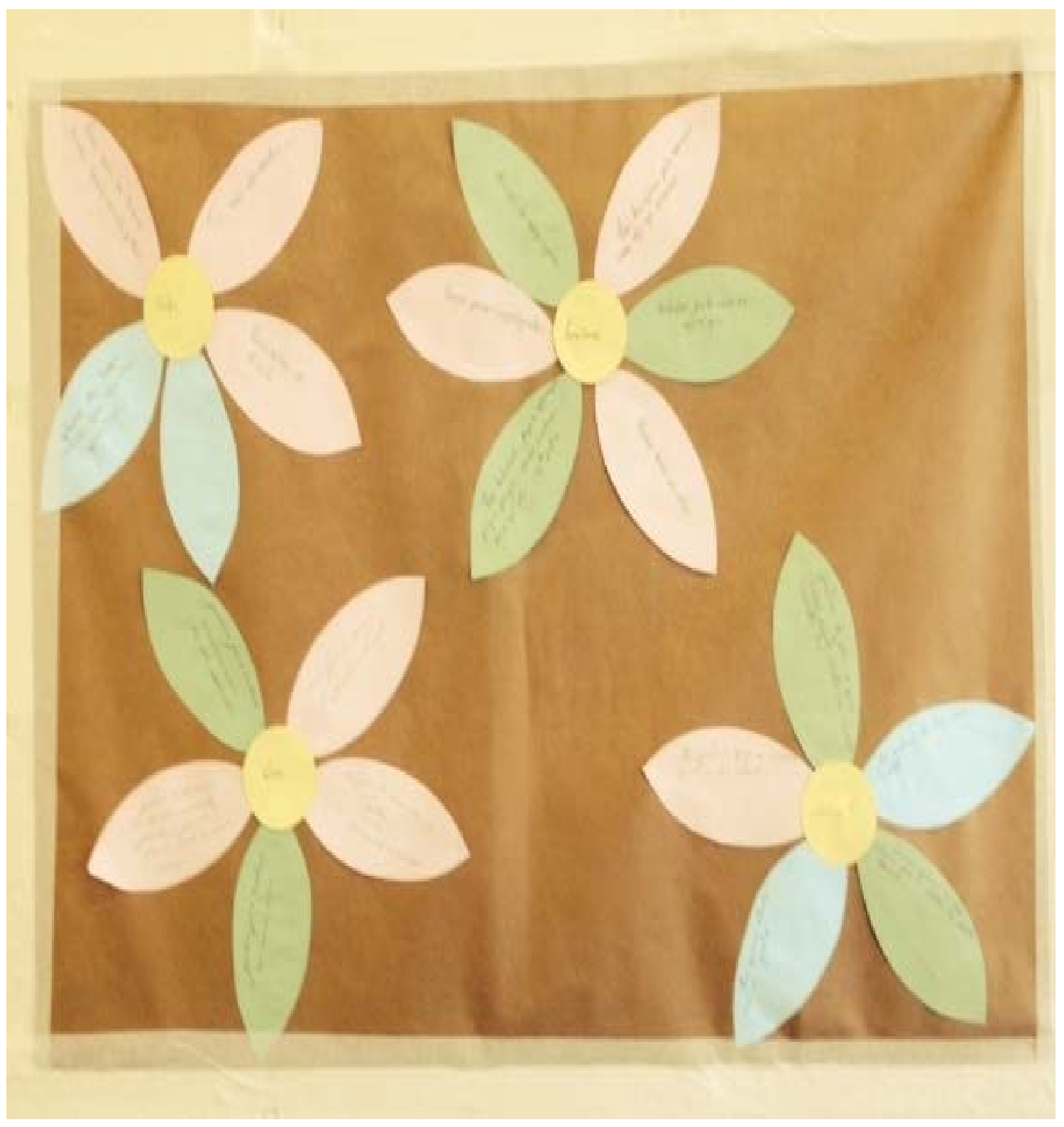


Apêndice 8- Música utilizada em atividades do encontro no 9

\section{$\underline{\text { Rosas }}$}

Atitude Feminina

A cada quinze segundos uma mulher é agredida no Brasil.

E a realidade não é nem um pouco cor-de-rosa.

A cada ano dois milhões de mulheres são espancadas

por maridos ou namorados.

Hoje meu amor veio me visitar

E trouxe rosas para me alegrar

E com lágrimas pede pra eu voltar

Hoje o perfume eu não sinto mais

Meu amor já não me bate mais

Infelizmente eu descanso em paz!

Tudo era lindo no começo, lembra?

Das coisas que me falou que era bom, sedução

Uma história de amor

Vários planos, desejo, ilusão

E daí?

Não tinha nada a perder

Queria sair dali

No lugar onde eu morava me sentia tão só

Aquele cheiro de maconha e o barulho de dominó

A molecada brincava na rua

E eu cheia de esperança

De encontrar no futuro um rapaz

Sem tiroteio, vingança

E ele veio como quem não quisesse nada

Me deu um beijo e me deixou na porta de casa

Os meus olhos brilhavam estava apaixonada!

Deixa de ser criança! - a minha mãe falava

Que no começo tudo é festa e eu ignorava

Deixa eu viver meu futuro, zipá

Muda nada menina boba iludida

Sabe de nada da vida

Uma proposta ambição de ter uma família

Entreguei até a alma e ele não merecia

O meu pai embriagado nem lembrava da filha

O meu príncipe encantado meu ator principal

Me chamava de filé e eu achava legal

No começo tudo é festa

Sempre é bom lembrar!

Hoje estou feliz o meu amor veio me visitar

Hoje meu amor veio me visitar

E trouxe rosas para me alegrar

E com lágrimas pede pra eu voltar 
Hoje o perfume eu não sinto mais

Meu amor já não me bate mais

Infelizmente eu descanso em paz!

Numa atitude pensada sai de casa

Pra ser feliz

Não dever satisfação ser dona do meu nariz

Não agüentava mais ver a minha mãe sofredora

Levar porrada do meu pai embriagado e a toa

Meu irmão se envolvendo com as paradas erradas:

cocaína, maconha, 157

Ah, mas eu estava feliz no meu lar doce-lar

Sua roupa olha só!

Tinha prazer de lavar

Mas alegria de pobre dura pouco, diz o ditado

Ele ficou diferente agressivo, irritado

Chegava tarde da rua aquele bafo de pinga

Batom na camisa e cheiro de rapariga

Nem um ano de casado, ajuntado sei lá

Não sei pra que cerimônia o importante é amar

Amor de tolo amor de louco, o que foi que aconteceu?

Me mandou calar a boca e não me respondeu

Insisti foi mal, ele me bateu

No outro dia me falou que se arrependeu

Quem era eu pra julgar?

Queria perdoar

Hoje estou feliz o meu amor veio me visitar

Eu tava a quatro meses grávida, ele me deu uma surra tão violenta que eu cai, desmaiei ai quando eu acordei eu tava numa poça de sangue assim que tinha saido da minha boca e do meu rosto ele me catou assim pelos meus cabelos me puxou e falou:

Você vai morrer!

Hoje o perfume eu não sinto mais

Meu amor já não me bate mais

Infelizmente eu descanso em paz

Quase dois anos e a rotina parecia um inferno

Que saudade da minha mãe

Desisti do colégio

A noite chega madrugada e meu amor não vinha

Quanto mais demorava, preocupada mais eu temia

Não estava aguentando aquela situação

Mais hoje tudo vai mudar ele querendo ou não

Deus havia me escutado há uns dois meses atrás

Aquele filho na barriga era esperança de paz

Tantos conselhos me deram de nada adiantou

Era a mulher mais feliz, o meu amor chegou

Que pena! 
Novamente embriagado.

Aquele cheiro de maconha

Inconfundível, é claro

Tentei acalma-lo ele ficou irritado

Começou a quebrar tudo loucamente lombrado

$\mathrm{Eu}$ falei que estava grávida ele não me escutou

Me bateu novamente mais dessa vez não parou

Vários socos na barriga, lá se vai a esperança

O sangue escorre no chão, perdi a minha criança

Aquele monstro que um dia prometeu me amar

Parecia incontrolável eu não pude evitar

Talvez se eu tivesse o denunciado

Talvez se eu tivesse o deixado de lado

Agora é tarde

Na cama do hospital

Hemorragia interna o meu estado era mal

O sonho havia acabado e os batimentos também

A esperança se foi pra todo sempre, amém!

Hoje meu amor implora pra eu voltar

Ajoelhado, chorando

Infelizmente não da

Agora estou feliz ele veio me visitar

É dia de finados, muito tarde pra chorar.

Hoje meu amor veio me visitar

E trouxe rosas para me alegrar

E com lágrimas pede pra eu voltar

Hoje o perfume eu não sinto mais

Meu amor já não me bate mais

Infelizmente eu descanso em paz!

É muito importante que o limite seja posto pela mulher

Não vou aceitar uma situação de violência dentro da minha casa! 
Apêndice 9-Pseudônimos das adolescentes na pesquisa

\section{Simone de Beauvoir (1908-1986)}

A escritora, filósofa e feminista francesa Simone de Beauvoir sempre esteve consciente de que seu pai esperava ter um filho, ao invés de duas filhas. Ele afirmava, "Simone pensa como um homem!" o que a agradava muito, e desde pouca idade Beauvoir distinguiu-se nos estudos.

\section{Maria Lacerda de Moura (1887-1945)}

Educadora brasileira que se notabilizou por seus escritos feministas. Em 1920, no Rio de Janeiro, fundou a Liga para a Emancipação Intelectual da Mulher, que lutaria pelo do sufrágio feminino (direito ao voto). Maria Lacerda de Moura é considerada uma das pioneiras do feminismo no Brasil, e certamente foi uma das poucas que observaram a condição feminina na perspectiva da luta de classes.

\section{Bertha Maria Julia Lutz (1894-1976)}

Bióloga brasileira especializada em anfíbios, pesquisadora do Museu Nacional. Foi uma das figuras mais significativas do feminismo e da educação no Brasil do século XX. Depois de tomar contacto com os movimentos feministas da Europa e dos Estados Unidos, Bertha criou as bases do feminismo no Brasil. Uma das principais bandeiras do feminismo à época era o sufrágio feminino.

\section{Nísia Floresta Brasileira Augusta (1810 - 1885)}

Educadora, escritora e poetisa potiguar. É considerada uma pioneira do feminismo no Brasil e foi provavelmente a primeira mulher a romper os limites entre os espaços público e privado, publicando textos em jornais, à época em que a imprensa nacional ainda engatinhava. Nísia também dirigiu um colégio para moças no Rio de Janeiro e escreveu livros em defesa dos direitos das mulheres, dos índios e dos escravos.

\section{Judith Butler (1956)}

Filósofa americana e uma das principais teóricas da questão contemporânea do feminismo. É professora da Universidade da Califórnia, nos Estados Unidos. 


\section{Maria da Penha Maia Fernandes (1945)}

Biofarmacêutica brasileira que lutou para que seu agressor viesse a ser condenado. Com 70 anos e três filhas, hoje é líder de movimentos de defesa dos direitos das mulheres, vítima emblemática da violência doméstica. Em 7 de agosto de 2006, foi sancionada pelo então presidente do Brasil Luiz Inácio Lula da Silva a Lei Maria da Penha ${ }^{1}$, que torna mais rigorosas as punições às agressões contra a mulher, ocorridas no ambiente doméstico ou familiar.

\section{Guacira Lopes Louro}

Doutora em Educação e Professora Titular aposentada do programa de Pós-Graduação em Educação da Universidade Federal do Rio Grande do Sul. Ajudou a fundar o GEERGE (Grupo de Estudos de Educação e Relações de Gênero) e coordena esse grupo de pesquisa desde 1990. Tem no currículo diversos publicado livros, assim como artigos e capítulos que em sua maioria tratam de questões de gênero e sexualidade sempre pensados pelo campo da Educação.

\section{Chiquinha Gonzaga (1847 - 1935)}

Compositora, pianista e regente brasileira. Foi a primeira pianista de choro, autora da primeira marcha carnavalesca com letra ("Ô Abre Alas", 1899) e também a primeira mulher a reger uma orquestra no Brasil. Em maio de 2012 foi sancionada a Lei 12.624 e instituindo o Dia Nacional da Música Popular Brasileira, comemorado no dia de seu aniversário.

\section{Naomi Wolf(1962)}

Escritora feminista norte-americana. Seu livro O Mito da Beleza, publicado em 1991, se tornou uma referência da terceira onda do feminismo ao analisar como a exigência de as mulheres se adequarem a um ideal de beleza feminina dificulta a ascensão das mulheres ao poder político e social. 
Apêndice 10 - Texto utilizado em atividades do encontro $\mathrm{n}^{\circ} 10$

\section{AS MENTIRAS QUE CONTAM SOBRE NÓS}

\section{"Desconstruir o mito de que mulheres são todas inimigas é um passo importante no combate ao machismo".}

Por Aline Valek, no blog Escritório Feminista.

\section{Inimigas. Invejosas. Recalcadas. Fofoqueiras.}

Foi isso que nos ensinaram: que não poderíamos confiar umas nas outras. Cochicharam em nossos ouvidos que mulher é tudo falsa. Disseram-nos que as outras eram interesseiras, traiçoeiras, que roubariam nossos namorados, que tentariam chamar mais a atenção, que eram vagabundas, sempre uma ameaça.

Ensinaram a lição e mostramos que aprendemos quando dizemos que "mulher trabalhando junta não presta", ou quando nos orgulhamos ao dizer "não tenho amigas mulheres", ou quando odiamos aquela garota sem motivo algum, ou todas as vezes que julgamos a sexualidade da colega ou ainda quando atacamos, humilhamos ou desprezamos a outra apenas para buscar as migalhas da aprovação masculina. Como pudemos acreditar nessas mentiras por tanto tempo?

É tentador acreditar que "somos diferentes das outras" para tentar colher as recompensas por ser uma "boa garota". Eu sei. O problema é que essas recompensas nunca virão. Se hoje odiamos as outras mulheres e não hesitamos em julgá-las, atacá-las ou excluí-las, nada impede que amanhã os dedos que apontam para elas se voltem para nós mesmas. Hoje, a vagabunda é a "outra"; amanhã pode ser eu ou você. Nenhuma de nós está imune - e por isso mesmo, por mais diferentes que sejamos, há muito mais em comum entre nós do que você possa imaginar.

Colocaram entre nós essa espessa cortina de rivalidade para que não sejamos capazes de nos enxergar de verdade. Para nos isolar. Para que, divididas, nos enfraqueçam.

Consegue imaginar a quem isso possa interessar? Se eu e você sempre nos considerarmos inimigas, vamos poder esquecer de combater as estruturas da sociedade feitas para nos manter nos nossos devidos lugares. Se eu e você nunca nos considerarmos aliadas, seremos mais facilmente vencidas. Parece até teoria da conspiração, mas basta olhar ao seu redor. Basta olhar para a sua própria vida. Então está na hora de tentar ver além dessa cortina e, ao invés de olhar para o que nos difere, tentar encontrar aquilo que nos aproxima. Talvez você se surpreenda ao encontrar do outro lado não esse estereótipo odioso que nos venderam, mas uma mulher igual a você. Um ser humano tão único, multifacetado, com falhas e atributos positivos, assim como você mesma.

Mas tome cuidado: transpor essa cortina, apesar de simples, é algo tão poderoso que vai deixar muita gente nervosa. Terão ataques de raiva, vão querer te ridicularizar, te calar, fazer você voltar para o seu estado anterior. Para muita gente, nada que mude pode ser algo bom. Mas você pode imaginar o motivo, né? Normal que essa gente fique tão insegura. Afinal, quando descobrimos que não precisamos lutar umas com as outras, podemos fazer coisas incríveis.

Imagine quanta coisa pode ser diferente se, ao invés de cerrarmos os punhos, 
estendermos a mão para aquela outra mulher. Imagine poder olhar para nossas irmãs negras, brancas, indígenas, jovens, velhas, bissexuais, transsexuais, héteros, lésbicas, magras, gordas, com ou sem deficiência, baixas, altas e ver que, mesmo com tantas diferenças, há algo profundo que nos conecta.

Com essa simples mudança de atitude e de pensamento vamos rasgar em mil pedacinhos e ainda sapatear em cima de uma das mais perversas mentiras que contam sobre nós. E, de quebra, ainda podemos conhecer novas amigas. Mulheres com quem vamos poder nos divertir, compartilhar momentos e contar com elas para o que der e vier.

Que possamos mandar um recado para as outras mulheres, e que não seja de ódio, desprezo ou julgamento; mas um "estamos juntas". Porque juntas somos mais fortes para combater as armadilhas machistas do nosso mundo. Porque só juntas sobreviveremos. 